\title{
DANIELA MURAMATSU
}

\begin{abstract}
Quantificação da gametogênese através de análises histológicas para estimar a reprodução sexuada de Madracis decactis Lyman, 1859 (Cnidaria, Anthozoa, Scleractinia) do litoral sul do Estado do Rio de Janeiro
\end{abstract}





\title{
DANIELA MURAMATSU
}

\author{
Quantificação da gametogênese através de análises \\ histológicas para estimar a reprodução sexuada de Madracis \\ decactis Lyman, 1859 (Cnidaria, Anthozoa, Scleractinia) do litoral \\ sul do Estado do Rio de Janeiro
}

Dissertação apresentada ao Instituto de Biociências da Universidade de São Paulo, como parte dos requisitos necessários para a obtenção de título de Mestre em Ciências, na área Zoologia.

Orientador:Prof. Dr. Fábio Lang da Silveira 

Muramatsu, Daniela

Quantificação da gametogênese através de análises histológicas para estimar a reprodução sexuada de Madracis decactis Lyman, 1859 (Cnidaria, Anthozoa, Scleractinia) do litoral sul do Estado do Rio de Janeiro.

102 páginas -2007

Dissertação (Mestrado) - Instituto de Biociências da Universidade de São Paulo. Departamento de Zoologia.

1.Gametogênese 2. Scleractinia 3 . Madracis I. Universidade de São Paulo. Instituto de Biociências. Departamento de Zoologia.

Comissão Julgadora:

$\operatorname{Prof}(a)$. Dr(a).

Prof(a). $\operatorname{Dr}(a)$.

Prof. Dr. Fábio Lang da Silveira 



\section{Agradecimentos}

Eu gostaria de expressar meus sinceros agradecimentos:

Ao meu orientador professor Fábio Lang da Silveira que me deu esta oportunidade, sempre disposto a conversar desde o início desta jornada, quando surgiram as primeiras idéias sobre o mestrado. Obrigada pelos conselhos, pelo companheirismo, pela sua generosidade.

Ao pessoal do Planeta Oceano que me acompanhou nas coletas, em especial ao Alexandre, André e Newbert que sempre nos deram a maior força para que pudéssemos fazer nosso trabalho, e também ao Marquinhos que foi meu companheiro de coleta em duas ocasiões.

Aos técnicos do Departamento de Zoologia, principalmente o Ênio que me ensinou e me orientou nos processos de histologia e coloração. Aos funcionários da Biblioteca do IB que sempre foram super solícitos e me ajudaram nas atividades de pesquisa e obtenção de livros e revistas.

Ao Conselho Nacional de Desenvolvimento Científico e Tecnológico (CNPq) pela concessão da bolsa de mestrado pelo Programa de Pós-Graduação em Zoologia do IBUSP. Ao chefe do Departamento de Zoologia, professor Miguel T. U. Rodrigues e ao diretor do Instituto de Biociências, professor João S. Morgante por permitirem o uso das instalações para o desenvolvimento do meu trabalho.

Às pessoas que colaboraram com opiniões e informações importantes para o trabalho: Sra. Sylvia Chada (ESEC Tamoios) por disponibilizar o Plano de Manejo, Fernanda Soares pela colaboração com os dados de pluviosidade, Sr. João Ricardo (CRESECB) pela doação do Atlas Solarimétrico, Profa. Olga Sato pela ajuda com os dados de temperatura, Beth pela força e disposição em sempre me ajudar e Prof. Carlos Rocha e Ricardo por disponibilizarem os equipamentos para o registro fotográfico.

Aos meus colegas de laboratório Sérgio, Helena, Linlcon, Lílian, obrigada pela companhia e pelas conversas. À todos os colegas e amigos que vêm me acompanhando desde a graduação, sempre presentes no meu dia-a-dia me dando força e compartilhando os momentos de alegria e tristeza. À Kátia (Katita) e Pati, minhas primeiras amigas desse "mundo da pesquisa" que sempre torceram por mim, me deram conselhos e participaram do meu amadurecimento como pesquisadora.

Aos meus pais, Mikiya e Neide por tudo: pelo exemplo de dedicação, perseverança, honestidade, pelo carinho, cuidado e amor que sempre tiveram comigo.

Às minhas irmãs Juliana e Flávia pelas conversas, brigas, por todos os momentos que compartilhamos juntas (não me esquecendo também do Dunke e da Tuca que também fazem parte da família).

Ao Saulo, pelo amor, pelos ensinamentos, pelo companheirismo, obrigada. 



\section{RESUMO}

Uma das espécies de coral pétreo zooxantelado com mais ampla distribuição no litoral brasileiro é Madracis decactis Lyman, 1859. M. decactis forma colônias incrustantes nodulares que podem atingir até $30 \mathrm{~cm}$ de diâmetro. O estudo da gametogênese foi realizado através de coletas bimensais na Baía de Ilha Grande, RJ durante 21 meses (agosto/2004-maio/2006), totalizando 10 coletas (12 colônias/coleta) (Licença IBAMA no. 201/2004). Foram realizados cortes histológicos de $7 \mu \mathrm{m}$, e de 10 até 16 pólipos por colônia foram analisados, totalizando mais de 1800 pólipos. A análise dos pólipos indicou que $M$. decactis é hermafrodita, com gametas localizados no mesmo lóculo gástrico, porém em mesentérios diferentes. A gametogênese durou cerca de sete meses. A ovogênese iniciou-se ao redor de outubro, enquanto que a espermatogênese teve inicio no final de fevereiro, ambas terminando em sincronia no final do mês de maio. O exame dos pólipos férteis indicou a presença dos estágios I, II e III de desenvolvimento para a ovogênese e dos estágios I, II, III e IV para a espermatogênese. Não foram encontrados embriões ou plânulas nos cortes histológicos, indicando talvez que estes estágios permaneçam pouco tempo no interior do pólipo. O pico da atividade reprodutiva ocorre entre os meses de fevereiro e abril com todas as colônias férteis contendo ovócitos principalmente no estágio III de maturação. A provável época de liberação de plânulas ocorre entre os meses de abril e maio, sob influencia das condições ambientais como a temperatura da água do mar, a irradiação solar e a pluviosidade. O presente trabalho forneceu informações básicas a respeito da biologia reprodutiva de Madracis decactis presente em llha Grande, sendo uma contribuição para outros estudos mais específicos na área de manejo e conservação de ambientes marinhos. 



\section{ABSTRACT}

One of the most wide distributed coral species along the Brazilian cost is Madracis decactis Lyman, 1859. M. decactis growths as nodular incrusting colonies that can reach up to $30 \mathrm{~cm}$ in diameter. In order to study the gametogenesis cycle, bimonthly collections were done at Ilha Grande Bay, Rio de Janeiro, during 21 months (August/2004May/2006), totaling 10 collections (12 colonies/collection) (License no. 201/2004). Histological sections of $7 \mu \mathrm{m}$ thick were done to analyze 10 to 16 polyps per colony (more than 1800 polyps in total). The analysis indicated that $M$. decactis is hermaphroditic, with male and female gametes developing at the same gastric loculi, but in different mesenteries. The gametogenesis lasted about 7 months, the oogenesis starts at October , while spermtogenesis starts at the end of February, both reaching the maturity in synchrony at the end of May. The exam of fertile polyps indicated the presence of stages I, II and III for oogenesis and I, II, III and IV for spermatogenesis. No embryo or planula were observed in the histological sections, indicating that maybe these stages stay for a short period inside the polyp cavity. The peak of reproductive activity was between February and April when all the polyps were fertile containing manly stage III oocytes. The releasing of planulae may happen between April and May, under the influence of environmental conditions as sea water temperature, solar insolation and rainy season. The present study has provided basic information about the reproductive biology of Madracis decactis from Ilha Grande Bay, and it may be a contribution to further studies about management and conservation of marine environments. 



\section{ÍNDICE}

1 - Introdução

1.1 Modos reprodutivos dos corais escleractínios.......................................................

1.2 Considerações sobre o gênero Madracis .........................................................

1.3 Considerações sobre o estudo da reprodução sexuada dos corais brasileiros.......6

2 - Objetivos ..................................................................................................11

3 - Materiais e Métodos

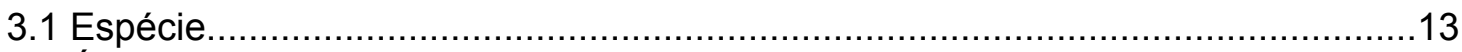

3.2 Área de estudo

3.2.1 Caracterização econômica........................................................................13

3.2.2 Caracterização ambiental.........................................................................14

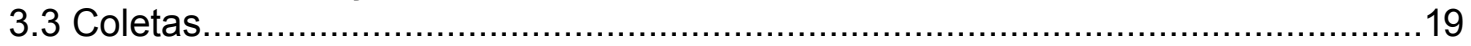

3.4 Processos histológicos e de coloração...........................................................19

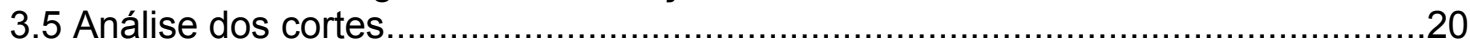

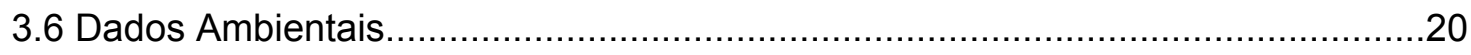

4 - Resultados

4.1 Distribuição e formas da colônia........................................................................23

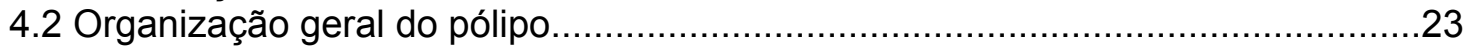

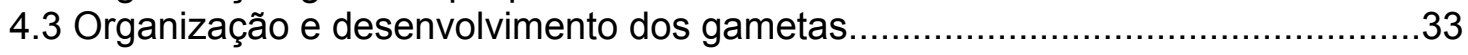

4.4 Estágios da

gametogênese.........................................................................

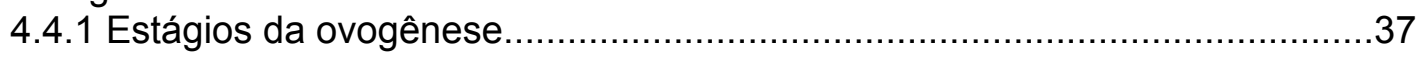

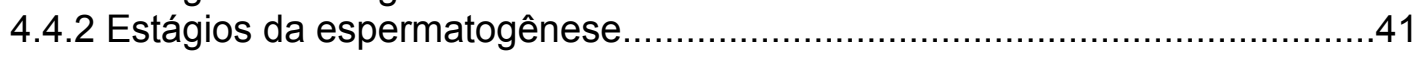

4.5 Ciclo reprodutivo

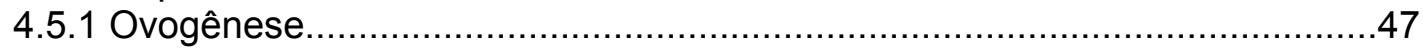

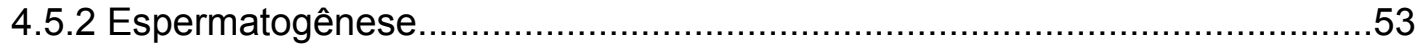

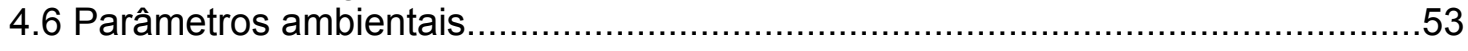

5 - Discussão

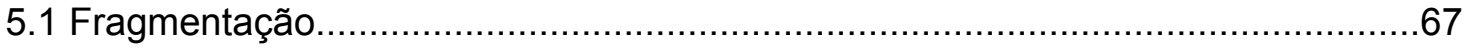

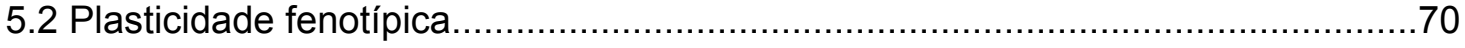

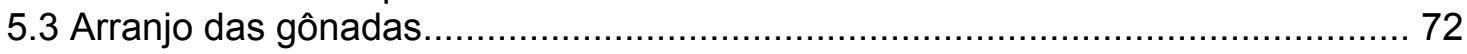

5.4 Estabelecimento dos estágios da gametogênese ................................................73

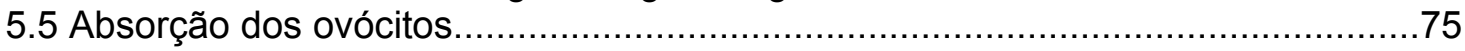

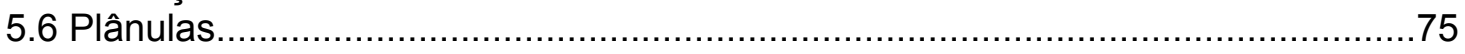

5.7 Ciclo reprodutivo

5.7.1 Fatores que influenciam no início e época do ciclo reprodutivo.....................77

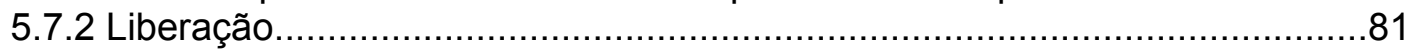

5.8 Considerações sobre os corais e os impactos ambientais................................... 87

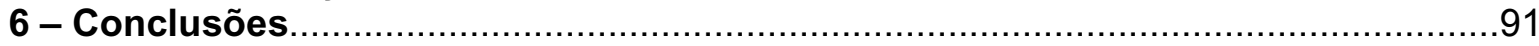

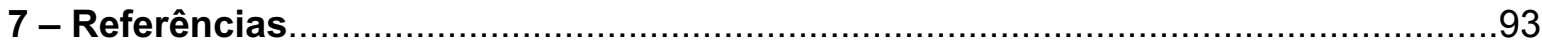





\section{1 - INTRODUÇÃO}

\subsection{Modos reprodutivos dos corais escleractínios}

Os corais escleractínios são cnidários relativamente conhecidos pelas pessoas, principalmente, quando nos referimos a ambientes marinhos de águas claras e quentes, apesar de muitos não saberem em que categoria os classificar, confundido-os com esponjas, "plantas" devido ao seu hábito de vida séssil e seu formato que às vezes lembra um galho, ou ainda algo inanimado, uma rocha, por exemplo (Oigman-Pszczol et al., 2007). Os mais conhecidos e populares são os corais pétreos zooxantelados, com cerca de 656 espécies reconhecidas (Cairns, 1999), que formam as comunidades coralínias e são os principais formadores dos diversos tipos de recifes espalhados pelas regiões tropicais que tanto atraem os turistas. Os corais pétreos azooxantelados possuem 669 espécies (Cairns, 1999), virtualmente o mesmo número de que os zooxantelados, mas são menos conhecidos, pois muitas vezes são encontrados apenas em grandes profundidades (Cairns, 1981; Kitahara \& Cairns, 2005), apesar de poderem ser bastante comuns também em águas rasas, como é o caso, por exemplo, dos corais exóticos Tubastrea coccinea e $T$. tagusensis que colonizaram muitos ambientes na região sudeste do Brasil, e que chamam bastante a atenção dos mergulhadores por causa de suas colorações vermelha ou laranja e seus tentáculos amarelos (Paula \& Creed, 2004; Creed, 2006).

Os corais escleractínios são animais sésseis e, uma vez assentados sobre o substrato, ficam submetidos às condições ambientais da região, não podendo se locomover nem para a alimentação ou reprodução e nem no caso das condições ambientais se tornem desfavoráveis. Talvez esse modo de vida (entre outros fatores) tenha favorecido o desenvolvimento de uma grande plasticidade tanto morfológica e fisiológica quanto reprodutiva ao longo de sua evolução. O corais podem, por exemplo, apresentar dois padrões sexuais: hermafroditismo ou gonocorismo; e dois modos de reprodução: fertilização externa com liberação de gametas na água ou fertilização interna com incubação da plânula dentro do pólipo feminino, resultando assim, em quatro combinações possíveis para os padrões reprodutivos (Harrison \& Wallace, 1990).

A grande maioria dos trabalhos a cerca da reprodução dos corais durante quase todo o século XX esteve voltada para a capturação de plânulas, mais do que para o estudo da gametogênese ou da liberação de gametas (Harrison \& Wallace, 1990). Assim, acreditava-se que o modo incubador de plânulas era predominante entre os corais, até que a partir da década de 80 houve um grande número de trabalhos relatando a liberação de gametas na coluna d'água bem como a fertilização externa, o 
que contribuiu para a concepção do modo liberador como o modo predominante na reprodução dos escleractínios (Harrison \& Wallace, 1990; Richmond \& Hunter, 1990).

Cerca de três quartos das espécies zooxanteladas são hermafroditas e liberam seus gametas na água para a fertilização externa (Harrison \& Wallace, 1990) sendo que esse modo de reprodução está geralmente associado com uma maior fecundidade (grande quantidade de gametas/plânulas por pólipo) e um potencial maior de dispersão devido ao elevado número de plânulas produzidas e também ao relativo longo período de 4 até 6 dias de desenvolvimento planctônico (Harrison \& Wallace, 1990; Veron, 2000a).

Devido à preponderância do modo liberador de gametas alguns autores sugeriram que esse seria o modo ancestral da reprodução dos Scleractinia, enquanto que o modo incubador seria secundariamente derivado em resposta às necessidades ecológicas e ambientais (Szmant, 1991; Shlesinger et al., 1998). Algumas hipóteses foram levantadas com o objetivo de se entender porque o modo incubador teria surgido, e quais seriam suas relações com a história de vida, morfologia ou habitat dos corais (Harrison \& Wallace, 1990). Stimson (1978) sugeriu que espécies de águas rasas (ambientes com maior distúrbio) teriam uma alta taxa de mortalidade e por isso a seleção deveria ter favorecido espécies com altas taxas reprodutivas. Entretanto, o fato dessas espécies liberarem plânulas ao invés de gametas parecia não ser consistente com a seleção de taxas reprodutivas altas, uma vez que menos plânulas poderiam ser produzidas que gametas. Assim, essa estratégia deveria ser uma adaptação ao rápido assentamento em águas com muito movimento garantindo assim novos recrutas, mais do que uma alta taxa reprodutiva, hipótese que também foi corroborada por Ward (1992). Entretanto, além de muitos corais incubadores serem encontrados em grandes profundidades, assim como muitos corais liberadores serem encontrados em águas rasas contrariando a idéia de que o modo reprodutivo estaria relacionado com a profundidade (Harrison \& Wallace, 1990), muitos trabalhos observaram que plânulas incubadas eram capazes de permanecer no plâncton por até 103 dias (Richmond, 1987) e portanto teriam um grande potencial para a dispersão (Harii et al., 2002) e que de fato poucas contribuíam para a manutenção da comunidade local (Miller \& Ayre, 2004; Sherman et al., 2005).

Van Moorsel (1983) sugeriu que as espécies incubadoras de habitats mais imprevisíveis eram, comparativamente, pequenas ou de vida curta, alcançavam a maturidade cedo e possuíam um período reprodutivo longo e muitos descendentes pequenos os quais constituíam um custo reprodutivo anual alto. Ao passo que, as espécies relacionadas que se localizavam em ambientes mais estáveis apresentavam características opostas. Szmant $(1986,1991)$ também considerou o modo incubador 
como sendo uma adaptação de colônias que se especializaram em persistir em habitat com distúrbios, e considerou esse modo reprodutivo como sendo uma adaptação a situações que requereriam alta taxa de recrutamento local. Essas colônias estariam sujeitas à taxas de mortalidade precoces e freqüentes e por isso iniciariam a reprodução sexuada ainda bem jovens, e apresentariam muitos ciclos reprodutivos por ano (compensando a produção relativamente baixa de plânulas por ciclo), resultando assim em altos índices de recrutamento ao contrário dos liberadores. Porém, nem todos os corais incubadores têm tamanho pequeno, como por exemplo, Acropora palifera do Indo-Pacífico (Kojis, 1986) e Madracis mirabilis do Caribe (Vermeij et al., 2003b) além de nem todos apresentarem muitos ciclos reprodutivos ao longo do ano (Tioho et al., 2001; Harii et al., 2001; Lins de Barros et al., 2003).

Rinkevich \& Loya (1979) sugeriram que espécies com pólipos pequenos teriam gônadas que se direcionariam para dentro da cavidade gastrovascular, teriam um número menor de ovócitos pequenos e incubariam as plânulas, enquanto que em espécies de pólipos maiores, o número de ovócitos seria maior e a fertilização seria externa. No entanto, Szmant-Froelich et al. (1980) propôs que com as informações disponíveis de Astrangia danae e de muitas outras espécies de corais caribenhos não era possível estabelecer uma relação universal entre o tamanho do pólipo, tamanho do ovócito e modo reprodutivo, idéia que também recebeu suporte de outros autores (Harrison \& Wallace, 1990; Schlesinger et al., 1998).

Assim, parece que até o momento nenhuma relação simples entre o modo de reprodução e a história de vida, habitat ou morfologia pode ser confirmada. Ele deve envolver um balanço refinado entre a abundância local (através do rápido assentamento) e ampla dispersão; auto-fecundação e fecundação cruzada e cruzamento entre espécies e hibridização (Veron, 2000a). Como resultado uma única espécie pode ter diferentes modos de reprodução, algumas têm plânulas que assentam rapidamente (Babcock, 1988; Dunstan \& Johnson 1998; Tioho et al., 2001), outras plânulas que se dispersam por longas distâncias (Richmond, 1987; Isomura \& Nishihira, 2001) e outras ainda que podem tanto incubar quanto liberar gametas, como por exemplo, Goniastrea aspera que deve liberar gametas e incubar plânulas ambos de forma sexuada (Sakai, 1997), Oulastrea crispata que é capaz de liberar gametas e plânulas sexuada ou assexuadamente formadas (Nakano \& Yamazato, 1992); e Pocillopora damicornis que parece produzir gametas e incubar plânulas assexuadamente formadas (Ward, 1992). Parece que até o padrão sexual, que é considerado bastante conservativo dentro das linhagens (Harrison, 1985), pode ser revertido dependendo da condição ambiental a que estão submetidas às espécies (Tomascik \& Sander, 1987). 


\subsection{Considerações sobre o gênero Madracis}

As famílias Acroporidae e Pocilloporidae (pertencentes à subordem Archaeocoeniina) dominam muitos recifes ao redor do mundo, não sendo raro encontrar corais das duas famílias crescendo juntos ao longo de extensas áreas de águas rasas (Kinzie III, 1996). Acroporidae é formada por quatro gêneros dos quais dois (Acropora e Montipora) possuem o maior número de espécies entre os gêneros atuais, enquanto que Pocilloporidae é formada por cinco gêneros dos quais três (Stylophora, Seriatopora e Pocillopora) muitas vezes dominam as comunidades onde ocorrem, e exceto pelo gênero Madracis, estão restritos ao Indo Pacífico e Pacífico Leste (Kinzie III, 1996). Uma das grandes diferenças entre as duas famílias é o modo reprodutivo: os dois gêneros mais especiosos de Acroporidae liberam seus gametas na água e realizam fertilização externa, enquanto que nos pociloporídeos o padrão de reprodução é mais diverso, podendo liberar os gametas na água, incubar as plânulas ou ambos (Kinzie III, 1996). Dos cinco gêneros pertencentes à família Pocilloporidea, Pocillopora é o que tem a biologia reprodutiva mais bem estudada (Stimson, 1978; Harriott, 1983b; Sttodart, 1983; Fadlallah 1985; Shlesinger \& Loya, 1985; Glynn et al., 1991; Ward, 1992; Tanner, 1996, Tioho et al., 2001).

Madracis Milne Edwards \& Haime, 1849 é o único gênero de Pocilloporidea que não está restrito ao Pacífico, ocorrendo na região do Caribe até as águas temperadas do Mediterrâneo e Atlântico Norte e Sul (Species 2000, 2007; Veron, 2000b). Delvoye (1988) publicou o primeiro trabalho sobre a gametogênese do gênero, estudando a espécie M. mirabilis de Curaçao, Caribe. Aliás, a maioria dos trabalhos publicados sobre o gênero estão restritos à região caribenha (Fenner, 1993; Bruno \& Edmunds 1997, 1998; Diekmann et al., 2001, 2002, 2003; Vermeij et al., 2003a, b, 2004; Vermeij \& Bak, 2002, 2003).

Veron (2000b) mudou a posição do gênero Madracis da família Pocilloporidae para a família Astrocoeniidae com base nas características da columela (Vermeij et al., 2004). Entretanto, Vermeij et al. (2003b, 2004) estudando as espécies de Madracis, observaram características reprodutivas (como o arranjo das gônadas, número de plânulas por pólipo) semelhantes às características encontradas em outros pociloporídeos, e sugeriram que o rearranjo taxonômico deveria ser ao nível de gênero e não de família. O presente trabalho optou por adotar a classificação taxonômica tradicional e considerou o gênero Madracis pertencente à família Pocilloporidea.

A maioria das espécies desse gênero são azooxanteladas (oito) e, ao contrário da grande parte dos gêneros de corais escleractínios que são monotípicos (apenas zooxantelados ou azooxantelados), Madracis também é representada por seis espécies 
zooxanteladas e duas facultativas (Cairns, 1999), formando um total de 16 espécies reconhecidas (Cairns, 1999; Veron, 2000; Vermeij et al., 2003a).

O gênero é caracterizado por uma forma de colônia plocóide ou subcerióide, formas de crescimento ramificadas, incrustantes e/ou nodulares com coralitos de tamanho pequeno $(<1,5 \mathrm{~mm})$ ou médio $(1,5-10 \mathrm{~mm})$ de formato poligonal com aparência de favo de mel. O número de septos varia de 8 até 10 , tem columela estiliforme proeminente e brotamento extratentacular (Neves et al., 2002; Neogene Marine Biota of Tropical America, 2004).

O estatus de algumas espécies desse gênero é bastante debatido, e a ampla plasticidade morfológica e a sobreposição de caracteres morfológicos são as principais responsáveis pelos fracos limites entre as espécies (Vermeij et al., 2003b). Fenner (1993), estudando espécies de várias localidades no Caribe sugeriu que Madracis mirabilis e $M$. decactis formavam espécies separadas e, apesar de ocorrerem juntas em águas rasas e bem iluminadas podiam ser facilmente distinguidas. Em contrapartida, $M$. decactis e $M$. pharensis apresentavam uma gama enorme de morfologias que se sobrepunham, apresentando formas ramificadas nodulares, nódulos irregulares incrustantes, formas mistas com áreas nodulares e incrustantes, e colônias grandes ou pequenas. A autor considerou que esse grande número de formas intermediárias da morfologia e coloração das colônias eram uma evidência de que $M$. pherensis era uma forma ou ecoforma de $M$. decactis resultante das diferentes condições ambientais experimentadas por cada uma, na medida em que ambas geralmente se localizavam em diferentes regimes de luz, sendo $M$. decactis mais comum em regiões bem iluminadas e M. pharensis em lugares mais crípticos.

Entretanto, Vermeij \& Bak (2002) encontraram uma sobreposição de ambas as espécies ao longo de todo o paredão recifal em Curaçao com mais de $50 \%$ das colônias pertencentes ao complexo $M$. decactis IM. pharensis não se adequando a combinação ecoforma-ambiente proposta por Fenner (1993). Os autores sugeriram que outros fatores além da luminosidade poderiam influenciar na morfologia das espécies, tais como a movimentação e a sedimentação da água. A distribuição bimodal (críptica e exposta) das colônias de cada espécie na mesma profundidade foi sugerida como uma indicação de um possível início de especiação. O mesmo foi sugerido por Diekmann et al. (2001), que considerou M. decactis e M. pharensis, juntamente com M. formosa, um complexo de espécies parafiléico com altos níveis de polimorfismos, e que isso poderia ser resultado de uma especiação muito recente dentro do clado.

Espécies que possuem características morfológicas semelhantes e poucas características diagnósticas podem apresentar diferenças nas estratégias reprodutivas que suportem o estatus de espécies distintas. Por exemplo, a legitimidade do estatus de 
espécies distintas entre os três tipos que formam o complexo no gênero Montastrea foi reforçada com evidências que mostraram o isolamento reprodutivo entre elas devido às diferenças nas características de fertilização e período de liberação, sugerindo uma limitação no potencial de hibridização entre elas (Knowlthon et al., 1997).

Entretanto, a maior parte das espécies de corais não são unidades que se reproduzem isoladamente (Willis et al. 2006) e devido à grande variação biogeográfica não existem diferenças marcantes entre elas, sendo que todas são, potencialmente, interconectadas pelas correntes oceânicas (Veron, 2006). As espécies do gênero Madracis parecem apresentar poucas diferenças na estratégia reprodutiva e grande potencial de hibridização (Diekmann et al., 2001; Vermeij et al., 2004). Cinco espécies de Madracis estudadas no Caribe (entre elas $M$. decactis) são hermafroditas incubadoras de plânulas, todas apresentaram o mesmo padrão da gametogênese, e poucas diferenças reprodutivas foram observadas (apenas no número e tamanho dos gametas femininos) (Vermeij et al., 2004). A planulação ocorre por um período prolongado que vai de março até dezembro, sendo o pico em setembro e outubro, possibilitando uma hibridização potencial entre elas (Vermeij et al., 2003b).

No Brasil três espécies, $M$. decactis, M. mirabilis e $M$. pharensis, foram encontradas ao longo da costa brasileira desde o Arquipélago de Fernando de Noronha, RN até São Sebastião, SP (Laborel, 1967, 1969/70). Ao contrário do observado em regiões do Caribe onde $M$. mirabilis e $M$. pharensis podem ser encontradas em águas mais rasas (5-10m) (Fenner, 1993; Vermeij \& Bak, 2002; Diekmann et al., 2001), na costa brasileira, $M$. mirabilis e $M$. pharensis ocorrem apenas em profundidades maiores que 30 m (Laborel 1969/70). Hoje é sabido que o gênero ocorre também nas regiões do Maranhão e Ceará, e se estende até Santa Catarina (Bertuol, 1998; Couto et al., 2003). Além do trabalho de Laborel, que remonta à década de 60 , de lá para cá apenas um trabalho específico a respeito deste gênero foi feito no Brasil (Castro \& Pires 2006).

\subsection{Considerações sobre o estudo da reprodução sexuada dos corais brasileiros}

Um dos grandes impulsos dados na pesquisa e conhecimento dos corais brasileiros se deu na década de 60 , com os trabalhos do biólogo francês Jacques $L$. Laborel derivados da campanha a bordo do cruzeiro francês "Calypso" de 1961 até 1964 ao longo da costa brasileira. Nesses trabalhos Laborel produziu uma lista dos principais organismos recifais encontrados desde o Ceará até Santa Catarina, registrando inclusive, pela primeira vez em águas brasileiras, a presença das espécies Madracis decactis, M. pharensis e Agaricia fragilis, além da descrição de uma nova espécie, Scolymia wellsi (Laborel, 1967, 1969/70). 
Segundo Leão et al., (2003), durante as últimas duas décadas houve um aumento significativo no número de pessoas interessadas e envolvidas com os estudos de recifes e comunidades coralíneas no Brasil, ao mesmo tempo em que as pressões e ameaças a esses ambientes também foram crescendo. Os autores destacaram que uma grande quantidade de dados sobre as comunidades coralíneas já foram gerados cuja maior parte está relacionada com o mapeamento das áreas recifais, caracterização física e geológica das estruturas recifais, informações sobre a conservação, proteção e manejo dos recifes, além de inúmeros dados sobre vários aspectos da flora e fauna recifal (algas, moluscos, peixes, esponjas, octocorais, fauna associada aos corais, branqueamento, etc.).

Os estudos a cerca da biologia reprodutiva dos corais escleractínios brasileiros, no entanto, parecem ter surgido apenas recentemente, entre o fim da década de 90 e início de 2000 (Tabela 1). Das dezesseis espécies de corais zooxantelados descritas para o Brasil, metade já foi estudada quanto aos seus aspectos reprodutivos, entre elas quatro espécies endêmicas: Mussismilia braziliensis, M. hartii, M. hispida e Siderastrea stellata. Parece que o número exato de espécies endêmicas ainda não é consenso entre os especialistas, além das cinco espécies tradicionalmente consideradas (as quatro acima descritas mais Favia leptophylla) (Castro \& Pires, 2001; Couto et al., 2003), outros autores consideram Favia gravida (Hetzel \& Castro, 1994; Leão et al., 2003) e Meandrina braziliensis também como espécies endêmicas (Neves et al., 2002; Neves et al., 2006). A maioria dos trabalhos está concentrada em dois estados, Rio de Janeiro e Bahia, principalmente no Complexo Recifal de Abrolhos que abriga todas as espécies de corais brasileiras e é a formação recifal mais importante do Atlântico Sul (Castro \& Pires, 2001).

Sete espécies presentes em Abrolhos foram estudadas quanto a sua biologia reprodutiva e ao analisarmos seus ciclos reprodutivos observamos que existe uma variação muito grande entre eles tanto na duração da gametogênese quanto na época de liberação dos gametas/plânulas (Tabela 1). A duração do ciclo reprodutivo varia entre 3 até 4 meses nas espécies Porites astreoides e Madracis decactis, respectivamente, e de 10-11 meses nas espécies do gênero Mussismilia e em Siderastrea stellata. A época da liberação ocorre praticamente em todos os meses do ano, desde eventos curtos com duração de cerca de um mês, até períodos extensos de cinco meses como no caso de Scolymia wellsi. Essa variação nos padrões reprodutivos entre as espécies da mesma região deve indicar que se fatores exógenos estão envolvidos na determinação dos processos reprodutivos, eles devem ser espécie-específicos e que cada espécie deve responder de forma diferente e independente à esses estímulos (Harriott, 1983a; Babcock et al., 1986). 
Apesar de existirem comunidades de corais desde o Maranhão até Santa Catarina, a costa brasileira não apresenta muitos recifes "verdadeiros", isto é, formados por corais, mas sim comunidades de corais e algas calcárias que crescem sobre 0 substrato duro (Castro \& Pires, 2001). Muitas espécies de corais têm seu limite de distribuição entre as regiões de Abrolhos e Santa Catarina, e abaixo da desembocadura do Rio Doce no Estado do Espírito Santo, nenhuma formação recifal é encontrada (Leão et al., 2003).

A distribuição das espécies em latitudes mais altas parece estar relacionada com os valores mínimos de temperatura, ação das ondas, turbidez da água e queda da luminosidade (Veron, 1974). Segundo Harriott \& Banks (2002), os fatores que regulam a capacidade de desenvolvimento de um recife estão relacionados com a presença ou ausência de distúrbios físicos e uma taxa de calcificação reduzida, assim como os fatores que limitam os padrões da diversidade de espécies estariam relacionados primeiramente com as correntes de água, temperatura, tolerância fisiológica, dispersão e recrutamento.

Entretanto, ao contrário do que se imaginava, as populações de corais que estão em altas latitudes apresentam intensa atividade reprodutiva (Van Woesik, 1995). Nozawa et al. (2006) encontraram altas taxas de fecundidade nas colônias $(76,7$ - 100\%) de seis espécies localizadas em alta latitude $\left(32^{\circ} \mathrm{N}\right)$ onde a média de temperatura anual varia entre 15 até $27^{\circ} \mathrm{C}$. Wilson \& Harrison (2003) também demonstraram que muitos corais localizados na costa leste da Austrália a $30^{\circ} \mathrm{S}$ eram sexualmente reprodutivos indicando, portanto, que os corais escleractínios são capazes de produzir gametas/plânulas em locais de alta latitude e baixas temperaturas.

No entanto, a baixa taxa de recrutamento nos locais de alta latitude pode limitar a formação e o desenvolvimento de populações de corais (Harriott \& Banks, 1995; Nozawa et al., 2006). Apesar do intenso esforço reprodutivo, o fracasso da progênie de Montastrea annularis em aparecer entre os juvenis assentados dos corais caribenhos, foi atribuído, entre outros fatores, ao pequeno sucesso no recrutamento, e não à falta de atividade reprodutiva (Szmant, 1991). Parece haver um declínio na taxa de recrutamento das espécies incubadoras, mas principalmente das liberadoras de gametas à medida que se aumenta a latitude, resultando numa maior proporção de espécies incubadoras nas regiões com populações mais isoladas (Harriott \& Banks, 1995; Tioho et al., 2001; Hughes et al., 2002). Alguns autores destacaram a importância do recrutamento local, bem como de recrutas externos para a manutenção das populações locais (Tioho et al., 2001; Bassim \& Sammarco, 2003; Miller \& Ayre, 2004; Nozawa et al., 2006). 
Miller \& Ayre (2004) destacaram que em populações periféricas, dado o seu relativo isolamento geográfico, processos ecológicos e evolutivos tais como a dispersão de plânulas e a seleção estariam atuando de forma diferente se comparadas às áreas tropicais. Além disso, as comunidades mais isoladas devem ser mais vulneráveis aos distúrbios (como o branqueamento, por exemplo) do que comunidades mais centrais e interconectadas, enfatizando assim a importância da preservação desses ambientes (Hughes et al., 2003). Perry \& Lacombe (2003) consideraram inapropriado olhar para uma comunidade marginal como um tipo de recife de coral "pobre" se comparado aos recifes e comunidades que se desenvolvem em latitudes mais baixas com águas claras e quentes. As comunidades marginais (ambientes caracterizados por grandes variações de temperatura, salinidade ou de nutrientes, pouca penetração de luz e saturação de aragonita) são diversas, bastante comuns e tem o potencial de persistirem e de se desenvolverem durante longos períodos. Assim, seria interessante pensar nesses ambientes como estados alternativos de desenvolvimento, sendo que seu estudo pode fornecer uma visão do estado e características futuras de recifes que se tornarão mais expostos às condições marginais devido às mudanças ambientais.

O presente trabalho aborda o estudo de características reprodutivas de Madracis decactis presente próxima ao seu limite sul de maior ocorrência conhecida, e tem como um dos objetivos contribuir para a geração de informações básicas a cerca da biologia reprodutiva dessa espécie, que apesar de não ser tão abundante e nem ter extensas áreas de cobertura, como Siderastrea stellata nos recifes de arenito do nordeste (Neves, 2004) e Mussismilia braziliensis em Abrolhos (Leão, 1999), junto com Mussismilia hispida são os únicos representantes de corais zooxantelados que ocorrem na região de Ilha Grande, RJ. Essa região é caracterizada por uma beleza natural ímpar formada por remanescentes da Mata Atlântica e inúmeras ilhas, e que infelizmente também é palco de muitas atividades conflitantes, o que torna necessário um gerenciamento correto que deve ser melhor conduzido se baseado numa compreensão maior das características e dinâmicas da região se quisermos ter sucesso no desenvolvimento das áreas costeiras, mas também minimizar os impactos gerados à esses ecossistema. 


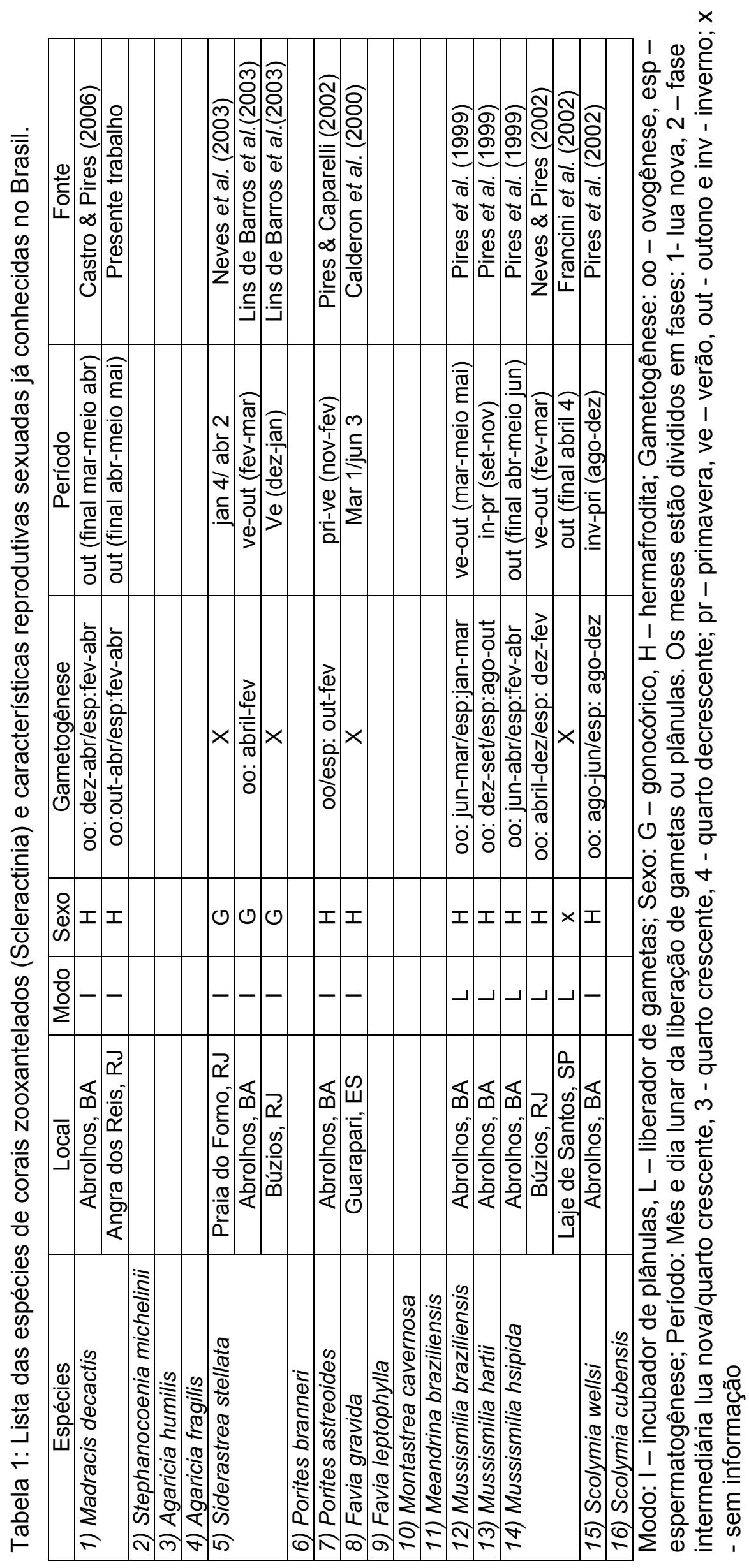




\section{2 - OBJETIVOS}

Pelo presente trabalho pretende-se:

1) Descrever o padrão sexual (gonocórico/hermafrodita) e o modo de reprodução (liberador de gametas/incubador de plânulas);

2) Descrever a gametogênese, ao nível de microscopia óptica, esclarecendo os padrões de ovogênese e espermatogênese, e estabelecer o provável período de liberação de gametas ou plânulas, bem como os fatores que influenciam na determinação do período reprodutivo;

3) Gerar conhecimento básico para subsidiar futuros estudos populacionais com objetivos conservacionistas. 


\section{3- MATERIAIS E MÉTODOS}

\subsection{Espécie}

Madracis decactis Lyman, 1859, juntamente com a espécie Porites astreoides Lamarck, 1816, são as espécies brasileiras que apresentam a mais ampla distribuição, pois ocorrem desde a região norte, no Parcel do Manuel Luiz, Maranhão, até o estado de Santa Catarina (Castro \& Pires, 2001).

Na região de Abrolhos, BA, $M$. decactis é encontrada em profundidades que vão de 3 até $10 \mathrm{~m}$. Suas colônias piramidais ou coluniformes são maiores, atingindo cerca de $30 \mathrm{~cm}$ de diâmetro (Laborel, 1969/70). M. decactis está ausente na região litorânea de Cabo Frio, RJ, apesar de ser bastante comum em profundidades rasas (2 a 5 m) na região da llha Grande, RJ (Laborel, 1969/70).

As colônias na região de llha Grande apresentam forma incrustante ou nodular e crescem em crostas sucessivas sob outros substratos duros. Em geral, a coloração da colônia viva é marrom, mas pode apresentar tons esverdeados ou arroxeados. Ocupam ambientes bem iluminados e rasos, e nessa situação formam colônias mais globulares com muitos nódulos, ou ocupam paredões verticais mais sombreados apresentando forma incrustante mais achatada.

\section{2 Área de estudo:}

\subsubsection{Caracterização econômica}

Podemos dizer que a década de 1970 foi o período de maiores transformações para a região de Angra dos Reis, pois foi quando o município passou a integrar grandes projetos de investimento, justificados pela política econômica nacional da época com fortes impactos na vida local. Até esse período havia uma certa harmonia entre as atividades econômicas tradicionais (pesca, agricultura e comércio) e a indústria nascente. Um dos investimentos mais expressivos foi a construção da rodovia federal Rio-Santos que trouxe um incremento significativo para a construção civil e acarretou num considerável aumento do setor terciário do município, sendo sem dúvida responsável pelas maiores transformações, tanto ao nível social quanto ambiental. Dos impactos trazidos pela Rio-Santos, destaca-se a viabilização dos empreendimentos turísticos (Ministério do Meio Ambiente, 2006).

O setor da pesca é o que mais emprega em Angra dos Reis, apesar da crise que vem abatendo essa atividade. Três tipos de pesca ocorrem no setor: pesca industrial (sardinha), pesca de pequeno porte (camarão) e pesca artesanal. As principais espécies capturadas são: sardinha, camarão, cação e peixes de fundo (corvinas, pescadas e outros). Até a década de 1970, havia na llha cerca de 10 
fábricas de salga de peixe, sardinha prensada e em lata. Foi quando começaram a aparecer vários problemas ambientais e econômicos em decorrência dessa atividade: desrespeito à época de desova da sardinha e defeso do camarão (ameaçando essas espécies de extinção); degradação dos ambientes costeiros e estuarinos; pesca predatória e ilegal realizada por barcos arrastões e dificuldade crescente de comercialização. Como resultado várias fábricas fecharam e foram transformadas em hotéis e pousadas, e hoje a pesca artesanal voltada para a subsistência é praticamente inexistente (Ministério do Meio Ambiente, 2006).

Atualmente, a economia da região está passando por uma fase de transição com o abandono das atividades tradicionais de pesca, agricultura e construção naval em prol de novas atividades como a construção civil, o turismo e a especulação imobiliária. Essa transição se baseia principalmente na beleza natural da região, mas ao mesmo tempo, é uma ameaça à própria natureza uma vez que cresce e se desenvolve de forma desordenada sem levar em consideração os limites de exploração e uso desses recursos naturais. O relativo bom estado de conservação e o charme do isolamento tornam as ilhas da Baía de Ilha Grande o principal recurso turístico da região (Ministério do Meio Ambiente, 2006).

\subsubsection{Caracterização ambiental}

O estudo foi realizado na região da Baía de Ilha Grande (Figura 1), delimitada pelos municípios de Angra dos Reis e Parati, sul do Estado do Rio de Janeiro. As

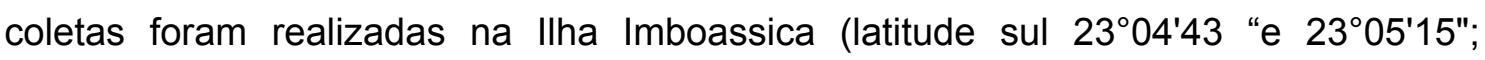
longitude oeste: $44^{\circ} 19^{\prime} 34$ "e $44^{\circ} 20^{\prime} 00^{\prime}$ ) que tem 13,2156 ha de área terrestre com vegetação arbórea em razoável estado de conservação, porém com presença de espécies exóticas e sinais de desmatamento e 924,8512 ha de entorno marinho (Ministério do Meio Ambiente, 2006). A llha está dentro e faz parte da Estação Ecológica (ESEC) de Tamoios criada em 1990 que abrange o entorno marinho e parcéis de mais 28 ilhas.

Nessa região a Serra do Mar ocorre junto ao litoral, paralelamente à costa, cuja variação topográfica do revelo é grande indo desde o nível do mar até $2000 \mathrm{~m}$. O litoral no entorno da Baía é bastante recortado, constituído por costões rochosos, praias, mangues e muitas ilhas (Soares, 2005). Nesse trecho litorâneo, as escarpar e o planalto montanhoso funcionam como uma barreira, dificultando a passagem das frentes frias vindas do Atlântico Sul e da Antártida, criando condições para altos índices de precipitação tornando o clima super úmido (Ministério do Meio Ambiente, 2006). 
Em geral as massas de águas presentes na Baía de llha Grande são resultados da mistura entre: Água Costeira (AC) resultante da mistura da descarga continental de água doce com as águas da plataforma continental; Água Tropical (AT) quente $\left(T>20^{\circ} \mathrm{C}\right)$ e salina na camada superficial da Corrente do Brasil $(0-200 \mathrm{~m})$ sobre o talude continental, nas proximidades da quebra da plataforma continental; Água Central do Atlântico Sul (ACAS) fria $\left(T<20^{\circ} \mathrm{C}\right)$ na camada inferior da Corrente do Brasil (200-500m) (Miranda, 1982; Castro et al., 2006). A camada mais interna da plataforma continental é ocupada principalmente pela AC que deve apresentar estratificação muito pequena devido aos processos de mistura causados pelos movimentos dos ventos na superfície e das correntes de marés no fundo (Castro et al., 2006). Durante o verão, as temperaturas são maiores que $21^{\circ} \mathrm{C}$, sendo em geral maiores que $22^{\circ} \mathrm{C}$, atingindo máximos de $27-28^{\circ} \mathrm{C}$. Enquanto que durante o inverno, as temperaturas são em geral menores que $22^{\circ} \mathrm{C}$ atingindo mínimos de $19-20^{\circ} \mathrm{C}$ (Castro, 1996).

A ocorrência de águas frias na região de Cabo Frio, principalmente nos períodos de primavera e verão, é um fenômeno conhecido de longa data (Castro et al., 2006). A ressurgência costeira é um fenômeno que se caracteriza pela ascensão da ACAS nas proximidades da costa. Essa ascensão transporta para a zona eufótica uma maior concentração de nutrientes estimulando as produções primárias e secundárias, podendo estender-se a $400 \mathrm{~km}$ de distância dos núcleos de ressurgência gerados nas proximidades de Cabo Frio, chegando até as proximidades da Ilha de São Sebastião (SP) (Miranda, 1982; Castro et al., 2006). A intrusão da ACAS na plataforma continental norte do Estado de São Paulo parece ser sazonal, cujo sinal é claramente identificado com a formação da termoclina na plataforma continental média (70-90m de profundidade) durante o verão (Casto, 1996). Dependendo das condições físicas e climáticas a ACAS pode penetrar até mesmo na parte mais interna da plataforma continental (Castro et al., 2006)

Segundo o Ministério do Meio Ambiente (2006), todas as ilhas pertencentes à estação ecológica sofrem influências das massas d'água descritas anteriormente, porém, com diferente intensidade. As ilhas localizadas abaixo da isóbata de $10 \mathrm{~m}$ e no interior da Baía da Ribeira podem estar sujeitas a uma maior influência do aporte continental e uma menor influência das águas da Corrente do Brasil e da ACAS. A Ilha Imboassica encontra-se no canal central (depressão estreita entre o continente e a llha Grande) entre as isóbatas de 20 até $25 \mathrm{~m}$, assim, é possível que as massas de água nessa região sejam 


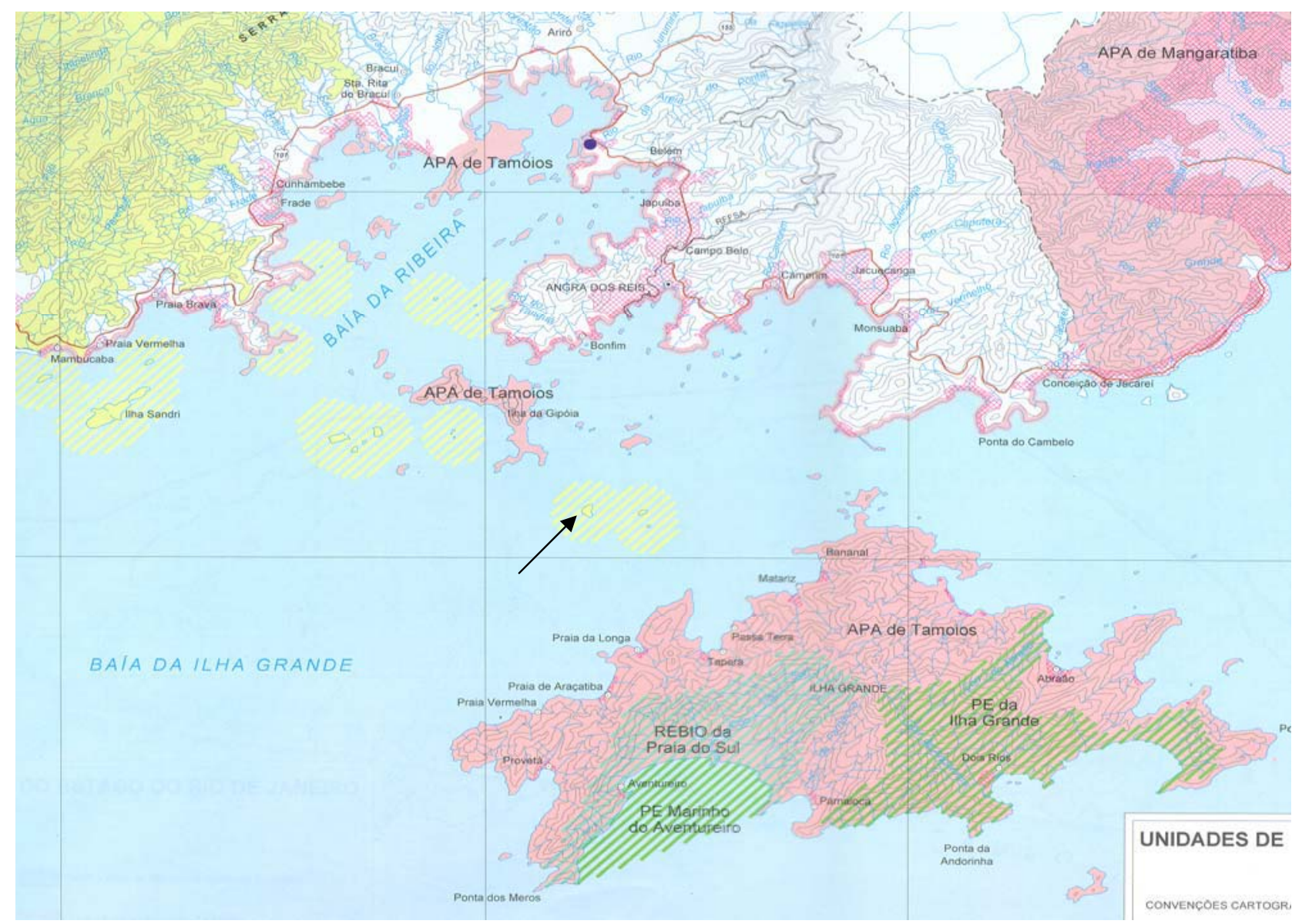

Figura 1: Mapa das Baías de llha Grande e Ribeira onde estão indicadas a llha Imboassica (seta) e a ESEC Tamoios (hachurado amarelo) (Secretaria do Meio Ambiente RJ,2001) 
pouco influenciadas pela ressurgência, sendo mais provável que as baixas temperaturas observadas durante o inverno ocorram devido à intrusão da AT em direção à costa (Castro, 1996).

\subsection{Coletas}

As coletas foram realizadas a cada dois meses, aproximadamente, iniciando em agosto de 2004 e terminando em maio de 2006, totalizando 10 coletas. Utilizandose equipamento de mergulho autônomo, doze colônias foram coletadas por coleta à 5 até $7 \mathrm{~m}$ de profundidade, totalizando 120 colônias.

O plano inicial era retirar de colônias maiores, com o auxílio de uma ponteira e um martelo, fragmentos menores com cerca de $3 \mathrm{~cm}^{2}$. Entretanto, logo nas primeiras coletas, observamos que no local ocorriam muitos fragmentos menores soltos no substrato inconsolidado. Colônias de Madracis decactis maiores também eram encontradas incrustadas em rochas, próximas aos fragmentos menores. Ao longo do costão da llha e em outras localidades da Ilha Grande (Lagoa Azul, Ponta Grossa, Ponta da Praia Vermelha) observamos a presença de colônias de formato nodular e também de formato incrustante.

Desta maneira, optou-se por coletar esses fragmentos menores soltos no substrato, ao invés de quebrar e danificar colônias maiores, facilitando também o trabalho de coleta. Os fragmentos coletados foram então colocados em solução de formol $4 \%$ e acondicionados em potes de vidro para o transporte para o laboratório.

\subsection{Processos histológicos e de coloração}

Para que a fixação do material ocorresse de forma satisfatória, as colônias trazidas para o laboratório foram mantidas em solução de formol $4 \%$ durante cerca de 2 até 3 meses antes de serem processadas.

Passado esse período, o material foi preparado para as análises histológicas seguindo-se a metodologia de rotina (Pires et al., 1999, 2002; Neves \& Pires, 2002). As amostras foram descalcificadas (quando necessário houve a troca da solução, deixando-as por mais $24 \mathrm{~h}$ ), e enxaguadas em água corrente por $24 \mathrm{~h}$.

Seguiram-se então as seguintes técnicas de preparação:

1 - Desidratação em série ascendente de etanol (10 - 100\%);

2 - Diafanização em xilol + etanol 100\% (1:1);

3 - Diafanização em xilol;

4 - Infiltração em Paraplast + xilol (1:1);

5 - Infiltração em Paraplast;

6 - Inclusão em Paraplast 
Utilizando-se o micrótomo rotativo manual, cortes de $7 \mu \mathrm{m}$ foram feitos a cada $200 \mu \mathrm{m}$ produzindo de 3 a 6 cortes/pólipo. Os cortes foram então montados em lâminas.

Para a coloração das lâminas adaptou-se um método de rotina utilizando-se Hematoxilina de Weigert e Tricrômico de Mallory (modificado de Morandini,1999 e Morandini \& Silviera, 2001):

1 - Desparafinar em xilol (3 banhos);

2 - Hidratação em série descendente de etanol (100 - 10\%);

3 - Coloração com Hematoxilina de Weigert (40 min);

4 - Azular em água de torneira (15 min);

5 - Diferenciar em álcool ácido $0,5 \%$ para retirar o excesso;

6 - Azular em água de torneira (10 min);

7 - Contra coloração com Tricrômico de Mallory soluções A e B (10 e 20 min);

8 - Enxaguar em água destilada;

9 - Desidratação em série ascendente de etanol (70 - 100\%).

\subsection{Análise dos cortes}

No plano inicial, 3 pólipos/colônia seriam escolhidos aleatoriamente para as análises dos ovários e testículos. Houve, porém, uma modificação nesse número por constatar que esse seria insuficiente, já que a espécie apresenta um grande número de pólipos de tamanho relativamente pequeno. Assim, de 10 a 16 pólipos/colônia foram analisados, sendo que para a seleção dos pólipos, deu-se prioridade aos cortes que apresentavam pólipos com os 10 pares de mesentérios íntegros.

Para a análise dos cortes, foram definidos os estágios de maturação dos gametas femininos e masculinos, baseados em Szmant-Froelich $(1980,1985)$ e Glynn et al. (1994). As medições dos maiores e menores eixos da célula e do núcleo foram realizadas apenas em células cujo nucléolo era visível. Para a análise dos espermatócitos mediram-se os eixos maiores e menores de apenas alguns espermatócitos nos diferentes estágios, já que os cistos continham uma grande quantidade de espermatócitos e estes apresentavam-se com tamanhos, aparentemente, constantes. Os eixos maiores e menores dos maiores cistos também foram medidos. Todas as medidas foram feitas sob o microscópio Wild M20 e a documentação fotográfica realizadas com recursos digitais.

\subsection{Dados ambientais}

Os dados da temperatura superficial da água do mar (tsm) foram obtidos através do "National Operation Model Archive and Distribuition System" (NOMADS Live Access Sever; http://nomads.ncdc.noaa.gov:8085/las/servlets/dataset) derivado 
do "National Oceanic \& Atmosferic Administration" (NOAA). As análises da tsm foram realizadas a partir de dados diários via satélite fornecidos pelo sensor de radiação "Advanced Very High Resolution Radiometer" (AVRHH) combinados com medições in situ de bóias e embarcações que são importantes para a calibração e a validação dos dados via satélite. O maior desafio nesse tipo de medição é eliminar a contaminação de nuvens e aerossóis (Reynolds et al., 2002), sendo que o erro global médio das medições é estimado em $0,3^{\circ} \mathrm{C}$ (Reynolds et al., 2002, 2006)

Os dados de irradiação solar foram obtidos através da Base se Dados do Atlas Solarimétrico do Brasil, publicado pelo Centro de Referência para Energia Solar e Eólica Sérgio de Salvo Brito (CRESESB). Os dados são referentes ao trabalho de Pedro Junior et al. (1989) que calcularam valores de irradiação solar médios diários em função da média de horas de brilho solar (insolação) durante o ano de 1989 para a região de Angra dos Reis, utilizando-se um heliógrafo Campbell Stokes. Dados de irradiação solar adicionais (via satélite) foram também obtidos do serviço "Surface Meteorology and Solar Energy" (http://eosweb.larc.nasa.gov/cgi-bin/sse/sse.cgi?) mantido pela "National Aeronautic and Space Administration" (NASA), referentes a média mensal do período de 10 anos (1983-1993) com desvio de $+0,7 \%$ até $-2,0 \%$.

Os trabalhos de Soares et al. (2005) e Soares (2005) forneceram as informações da distribuição espacial da precipitação na região hidrográfica da Baía de Ilha Grande e entorno através de dados de 31 estações pluviométricas disponibilizadas pela DAEE-SP (Divisão de Águas e Energia Elétrica do Estado de São Paulo) e ANA (Agência Nacional da Águas), no período de 1970 até 1999. Além disso, dados complementares da caracterização climática da região foram obtidos no Plano de Manejo do Parque Nacional da Serra da Bocaina (Ministério do Meio Ambiente, 2000), que forneceu informações sobre o regime pluviométrico do Parque e entorno com base nas medições obtidas nos postos e estações pluviométricas da DAEE e INMET (Instituto Nacional de Meteorologia). 


\section{4 - RESULTADOS}

\subsection{Distribuição e formas da colônia}

As colônias de Madracis decactis na llha Imboassica apresentaram uma distribuição bastante particular. A princípio, esperávamos encontrar colônias nodulares fixadas no substrato duro, e assim, para coletar, teríamos que utilizar uma ponteira e um martelo para a retirada de fragmentos centrais dessas colônias. No entanto, encontramos um panorama diferente do esperado.

De fato, algumas colônias nodulares dispersas ao redor da llha foram observadas fixadas no substrato, com diâmetro máximo de cerca de $30 \mathrm{~cm}$ (Figura 2). Parece que o crescimento da colônia se dá através do encobrimento de substratos duros (corais mortos ou rochas), como se fossem formas incrustantes, que ao invés de crescerem apenas paralelas ao substrato, formam também nódulos.

Entretanto, o que mais nos chamou a atenção foi uma determinada área do paredão da llha, entre as profundidades de 5 à $7 \mathrm{~m}$, onde encontramos uma alta freqüência dessas colônias soltas, uma bem próxima à outra (Figura 3). Essas colônias não pareciam ser derivadas diretamente do assentamento, mas da fragmentação de partes de outras colônias maiores. Muitos desses fragmentos, bem como as colônias que se encontravam fixadas no substrato, apresentavam partes mortas que expunham o exoesqueleto calcário ou que eram encobertas por algas, esponjas ou colônias de briozoários e ascídias (Figuras 4). Essas partes mortas eram intercaladas com áreas, aparentemente, saudáveis de tecido vivo. Além disso, após o processo de descalcificação do exoesqueleto, muitos poliquetas e moluscos bivalves perfuradores, a maioria do gênero Lithophaga $\mathrm{sp}$, foram encontrados dentro do esqueleto calcário. Como explicado anteriormente no capítulo de Materiais e Método, esses fragmentos soltos no substrato foram coletados e utilizados no presente trabalho (Figura 5).

Além da forma fragmentada, foram observadas formas de crescimento incrustante que apresentavam um relevo mais plano e menos nodular, e encontravamse em áreas mais sombreadas, crescendo em paredes verticais. A coloração dessas formas era mais escura, passando do marrom até um roxo escuro (Figura 6).

\subsection{Organização geral do pólipo}

O pólipo de Madracis decactis possui tamanho relativamente pequeno. 0 coralito mede de 1 até $2 \mathrm{~mm}$ de diâmetro (Figura 7). Vinte tentáculos distribuem-se ao redor da boca, sendo que para cada par de tentáculos existe um par de mesentérios 


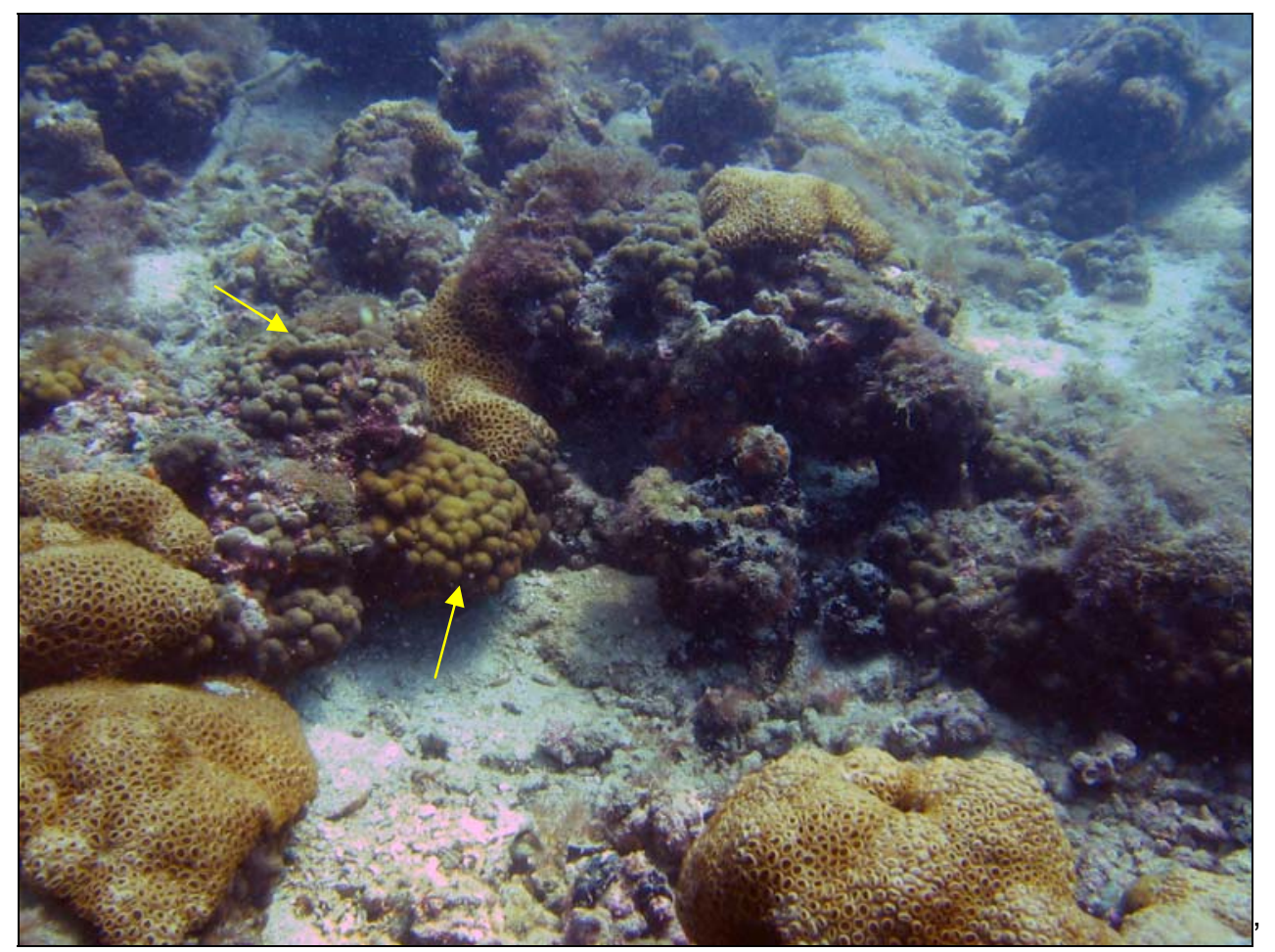

Figura 2: Ilha Imboassica, RJ, 18/03/2006, local de coleta, colônias de Madracis decactis presas no substrato (setas).

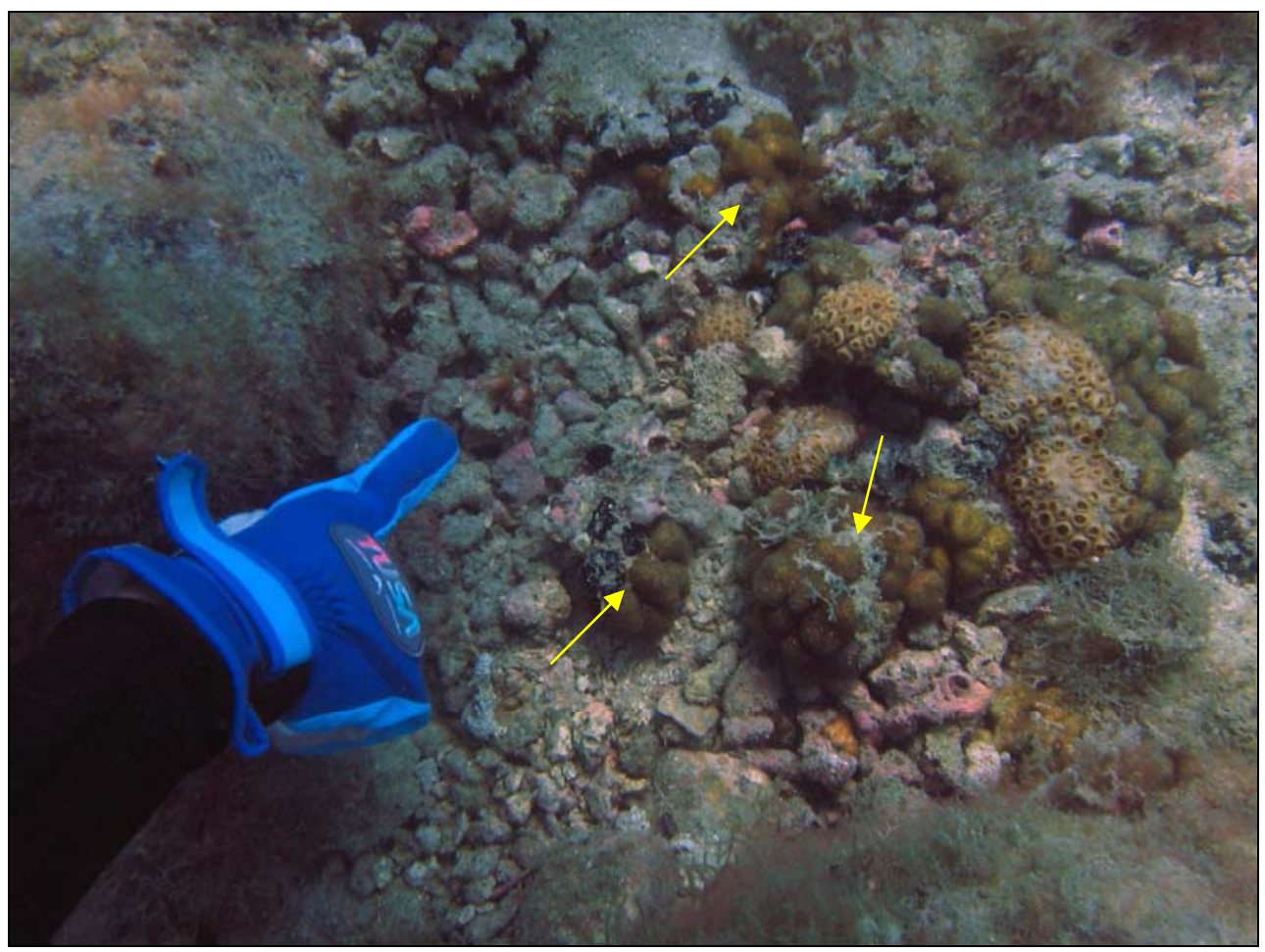

Figura 3: Ilha Imboassica, RJ, 18/03/2006, fragmentos soltos de $M$. decactis (setas) junto com material rolado. 


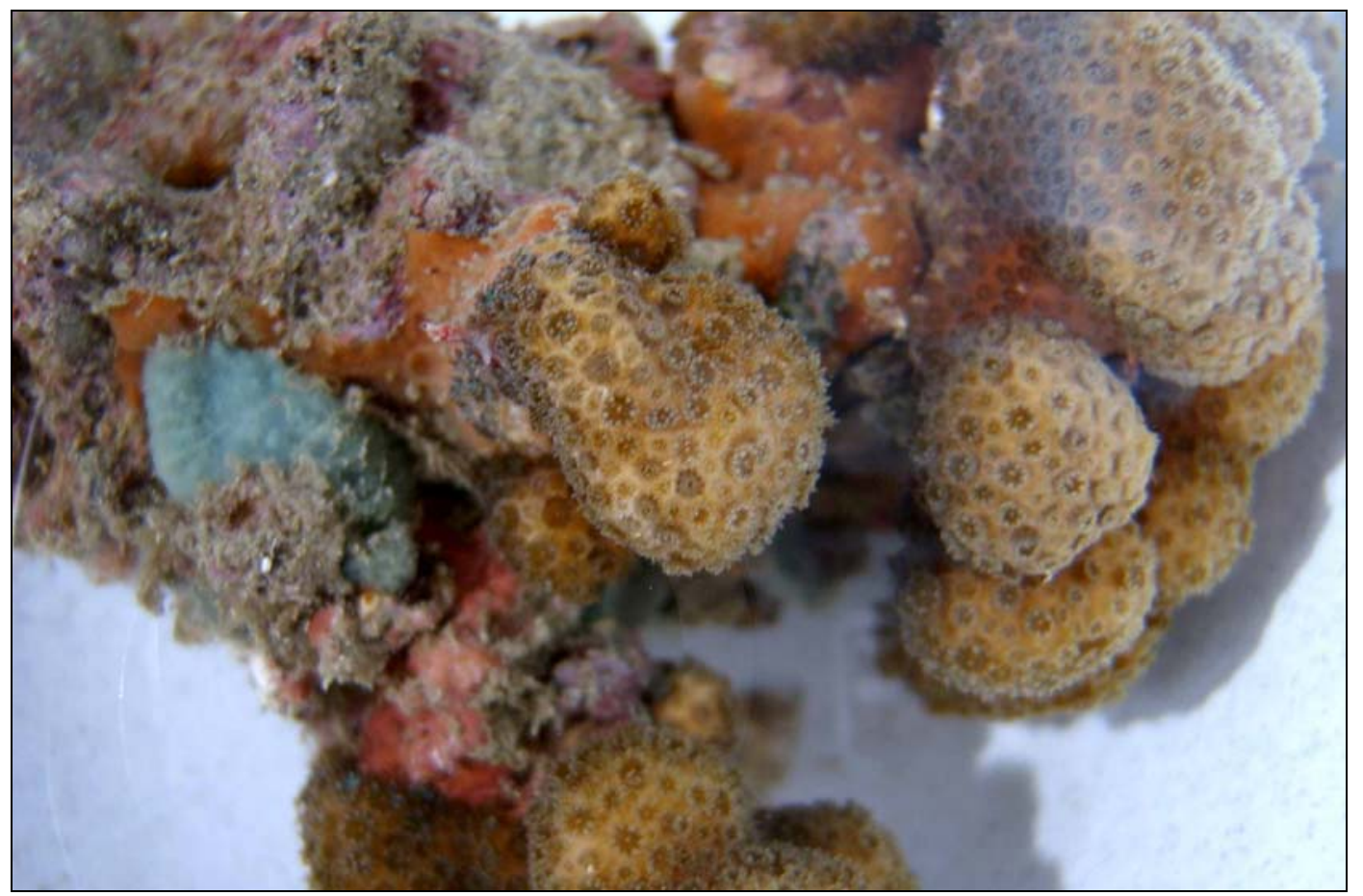

Figuras 4: Ilha Imboassica, RJ, 12/12/2004, colônias de $M$. decactis com exoesqueleto exposto encoberto por outros organismos.

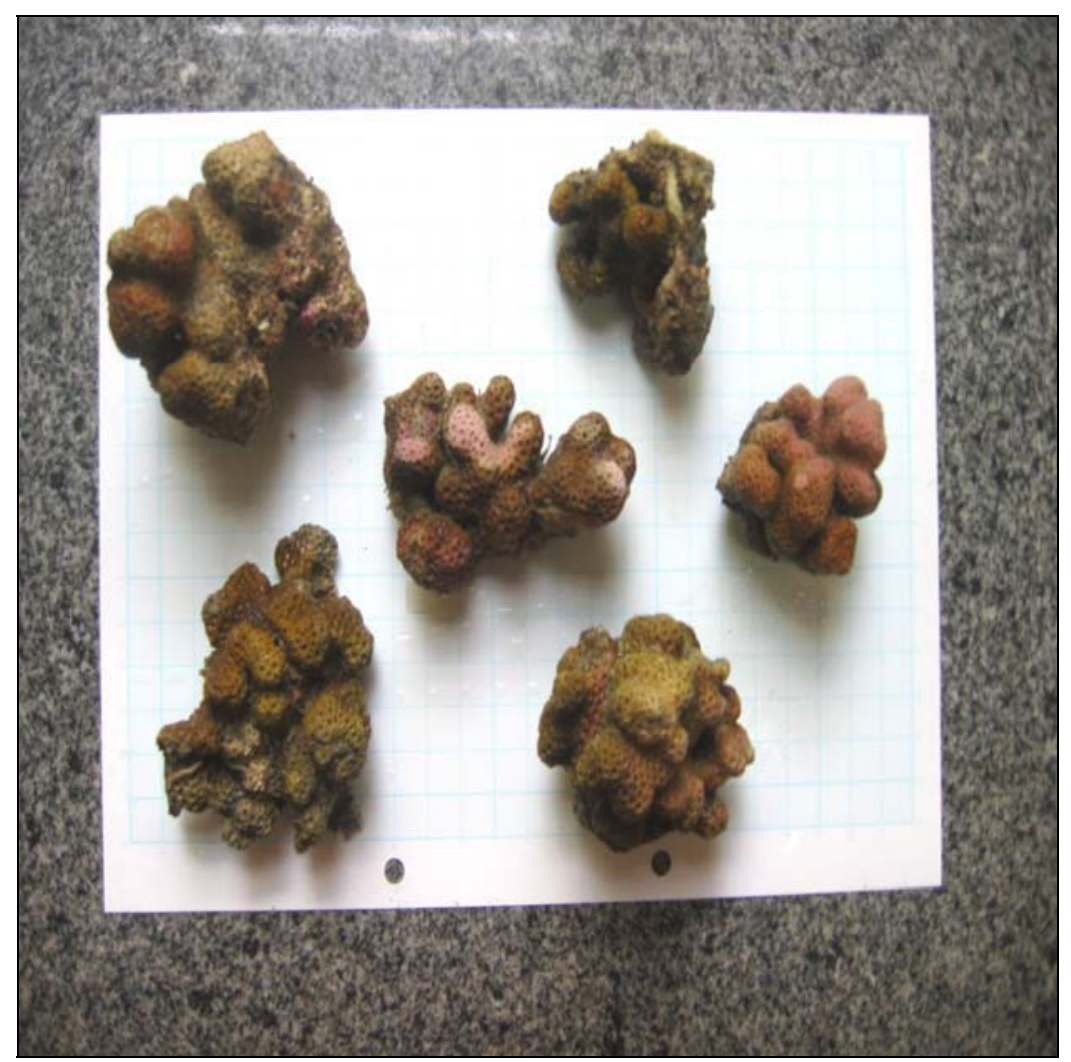

Figura 5: Fragmentos coletados sobre papel milimetrado. 


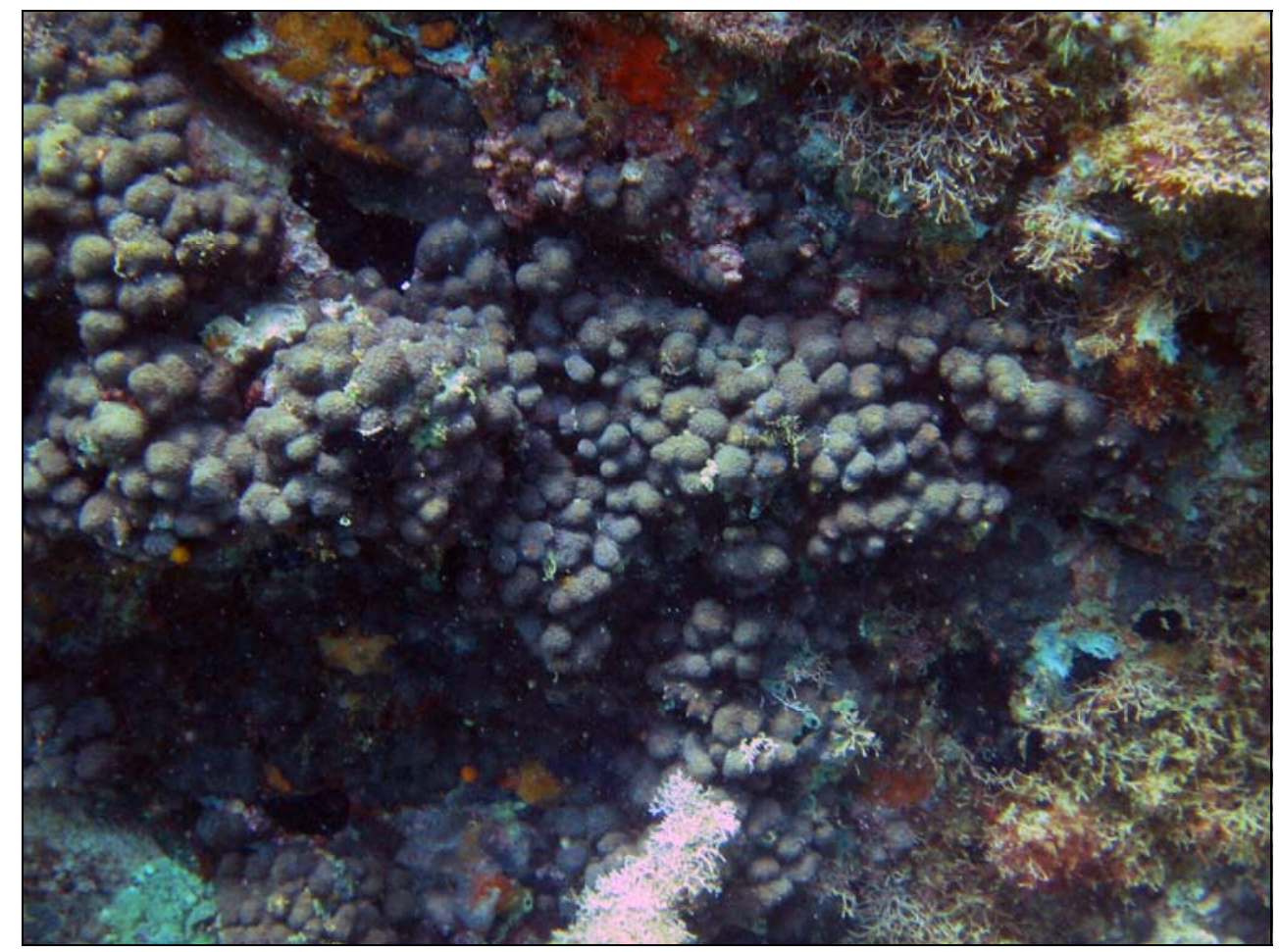

Figura 6: Ilha Imboassica, RJ, 19/03/2006, forma incrustante de M. decactis, crescendo em substratos verticais mais sombreados.

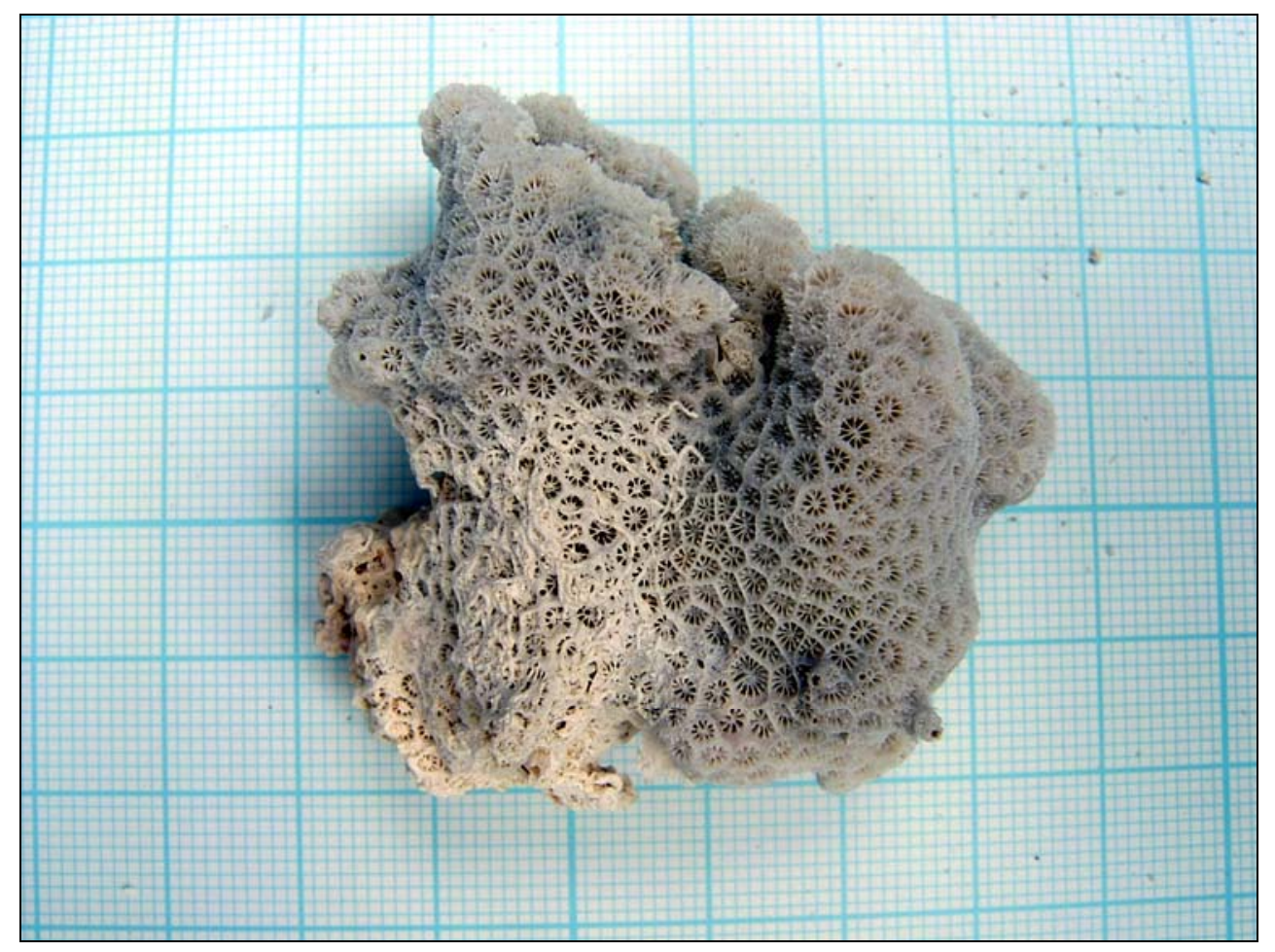

Figura 7: Exoesqueleto com coralitos pequenos (fundo papel milimetrado). 


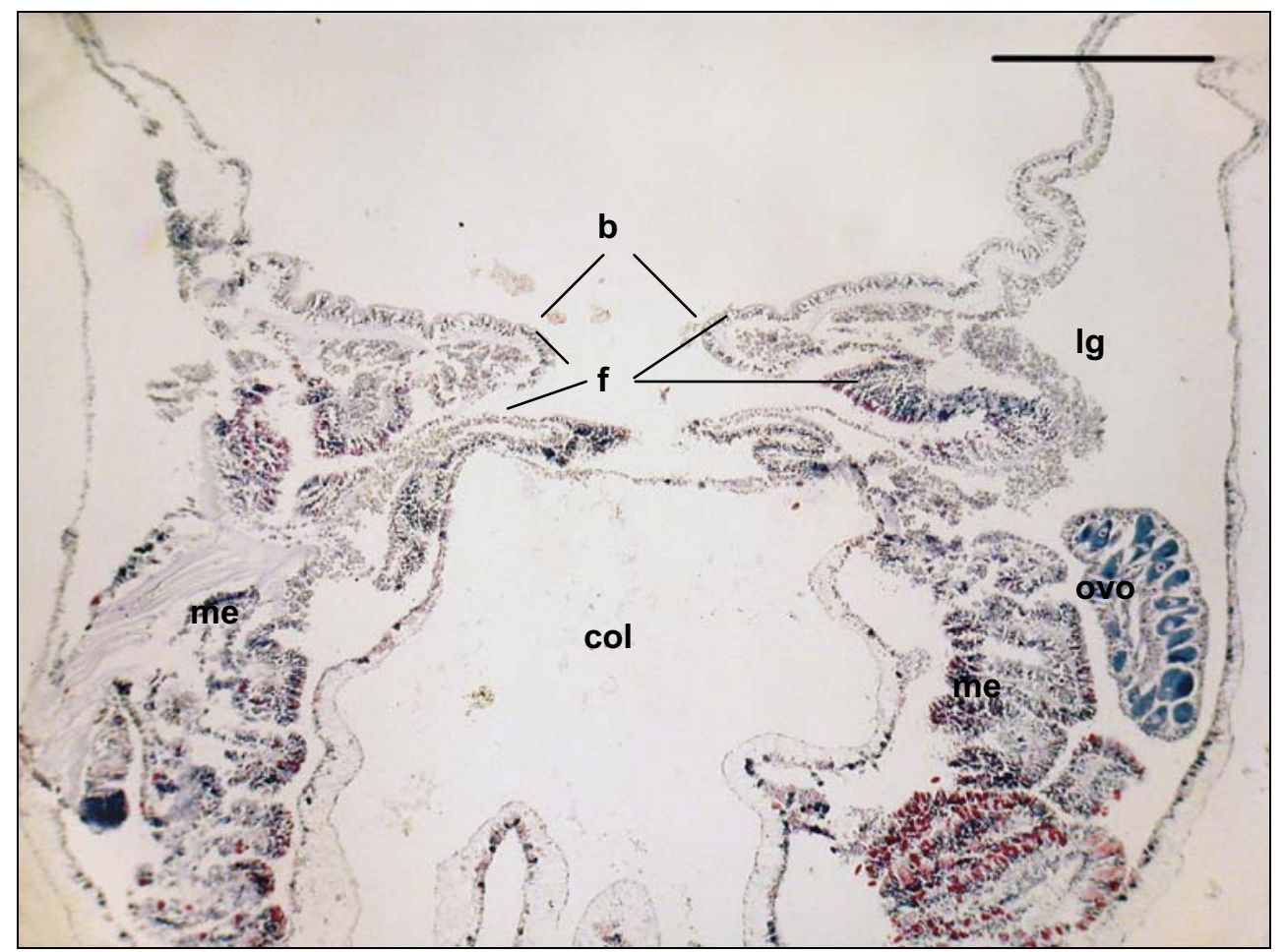

Figura 8: Corte longitudinal de um pólipo passando pela região da faringe: $b$ : boca; f: faringe; lg: lóculo gástrico; ovo: ovócitos; me: mesentério; col: região da columela (escala $300 \mu \mathrm{m})$.

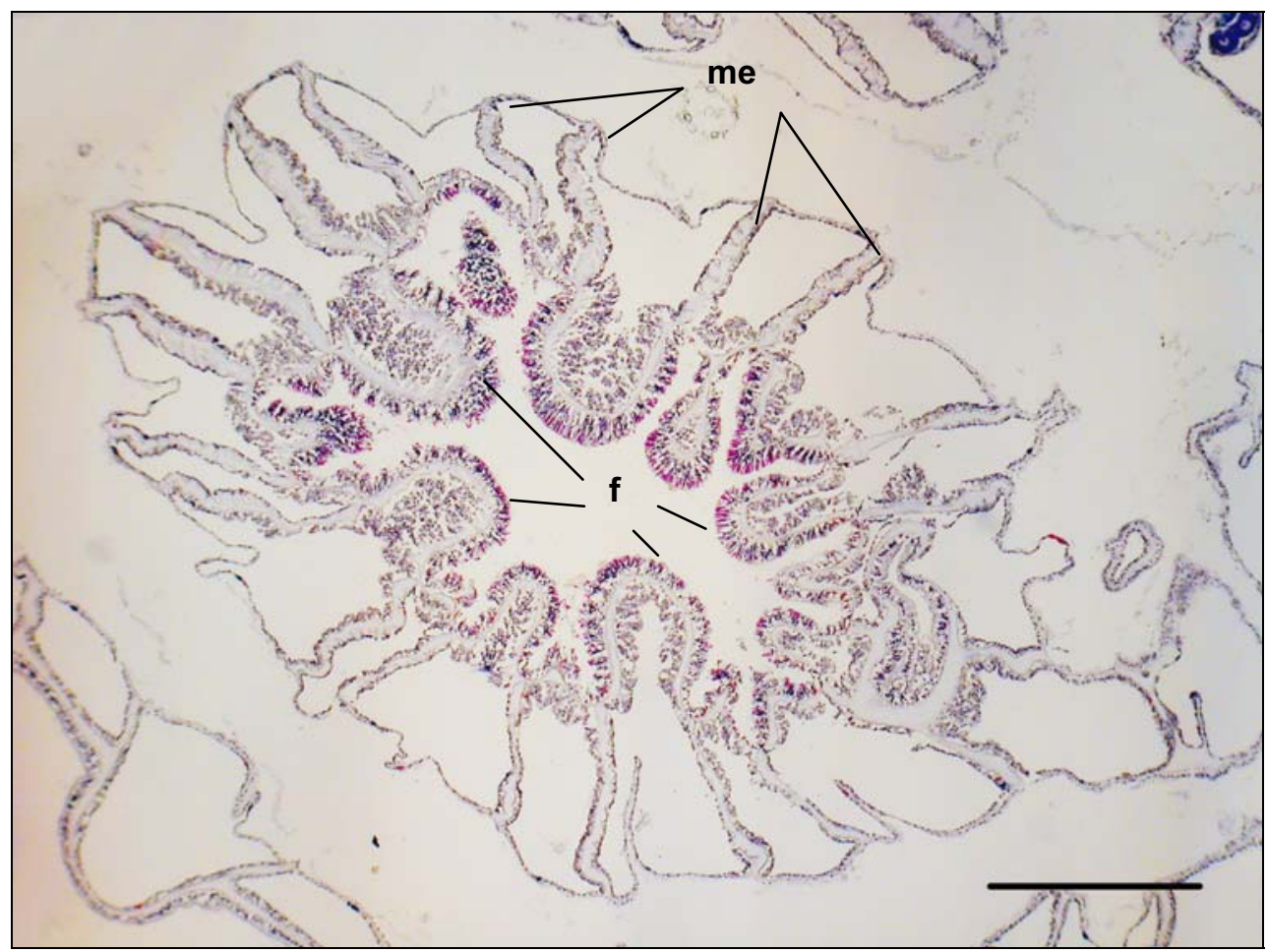

Figura 9: Corte transversal na altura da faringe (contraída devido à preparação) com muitos espirocistos (coloração rosa), e dez pares de mesentério conectados à ela: f: faringe; me: mesentério (escala $300 \mu \mathrm{m})$. 
correspondente, totalizando, portanto, vinte mesentérios por pólipo. Eles se desenvolvem dentro dos lóculos gástricos que são separados pelos septos calcários.

Os dez pares de mesentério se conectam à faringe que é curta e apresenta uma grande quantidade de cnidas do tipo espirocisto caracterizadas por apresentarem uma cápsula alongada, com um túbulo longo disposto em várias espiras que se cora intensamente de rosa (Figuras 8 e 9). Abaixo dessa região, os mesentérios exibem na extremidade dos filamentos muitas células glandulares e cnidas do tipo nematocisto, formando a região cnido-glandular. Pires (1995) observou a presença de quatro tipos de nematocisto nessa região: holótrico I, b-rabdóide (2), p-rabdóide $\mathrm{D}(2)$ e p-rabdóide $D(3)$. Foi difícil a visualização de b-rabdóides (2) e p-rabdóides $D(3)$ devido, provavelmente, às pequenas dimensões desses tipos de nematocistos e também à técnica de histologia utilizada. O tipo p-rabdóide $\mathrm{D}(2)$ apresentou coloração amarronzada e um "funil" em forma de "V" facilmente observável. O túbulo desse nematocisto tem duas regiões bem delimitadas, sendo o funil a passagem de uma região a para a outra (Pires, 1985). Os holótricos I foram observados mais na porção final do filamento, freqüentemente associados às células glandulares que têm seu conteúdo intensamente corado de vermelho. São os nematocistos de maior dimensão dos Anthozoa por isso são facilmente observáveis (Pires, 1995), seus túbulos longos, corados de rosa, são dotados de espinhos e estão dispostos helicoidalmente no interior da cápsula que se cora de azul.

\subsection{Organização e desenvolvimento dos gametas}

A análise histológica de Madracis decactis indicou que a espécie é hermafrodita. Os ovócitos e espermatócitos estão localizados no mesmo lóculo gástrico, porém em mesentérios distintos, sendo que o feminino é mais curto e não possui a região cnido-glandular na extremidade, e o masculino é mais longo, e apresenta essa região bastante desenvolvida (Figura 10). Em raras ocasiões foram observados lóculos contendo mesentérios de apenas um sexo.

Os gametas desenvolvem-se na área entre a musculatura longitudinal e a extremidade do mesentério. Observou-se um espessamento da gastroderme na região próxima ao desenvolvimento inicial dos gametas (Figura 11). À medida que essas células foram se desenvolvendo, a gastroderme e a mesogléia tornaram-se mais finas e menos desenvolvidas. Em alguns cortes, ovócitos e/ou cistos pareciam se posicionar mais lateralmente ao mesentério (Figuras 12A). Entretanto, na maioria das vezes, os ovócitos e cistos encontravam-se dentro do mesentério, padrão encontrado na maioria dos corais (Figura 12B). 


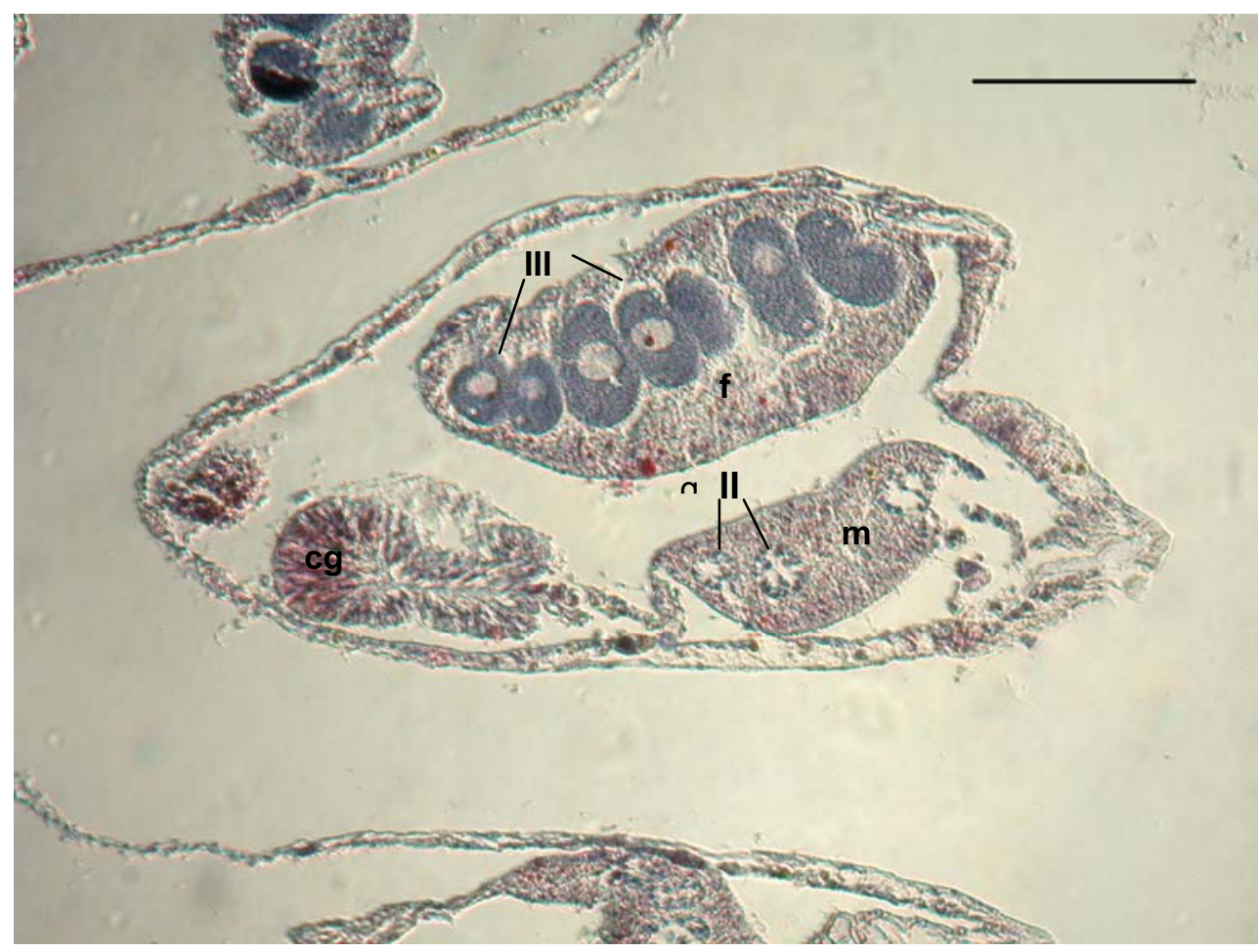

Figura 10: Corte transversal de um lóculo típico, com um mesentério feminino (f) contendo ovócitos III e um mesentério masculino $(\mathrm{m})$ com cistos II e a região

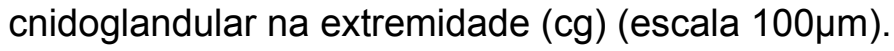

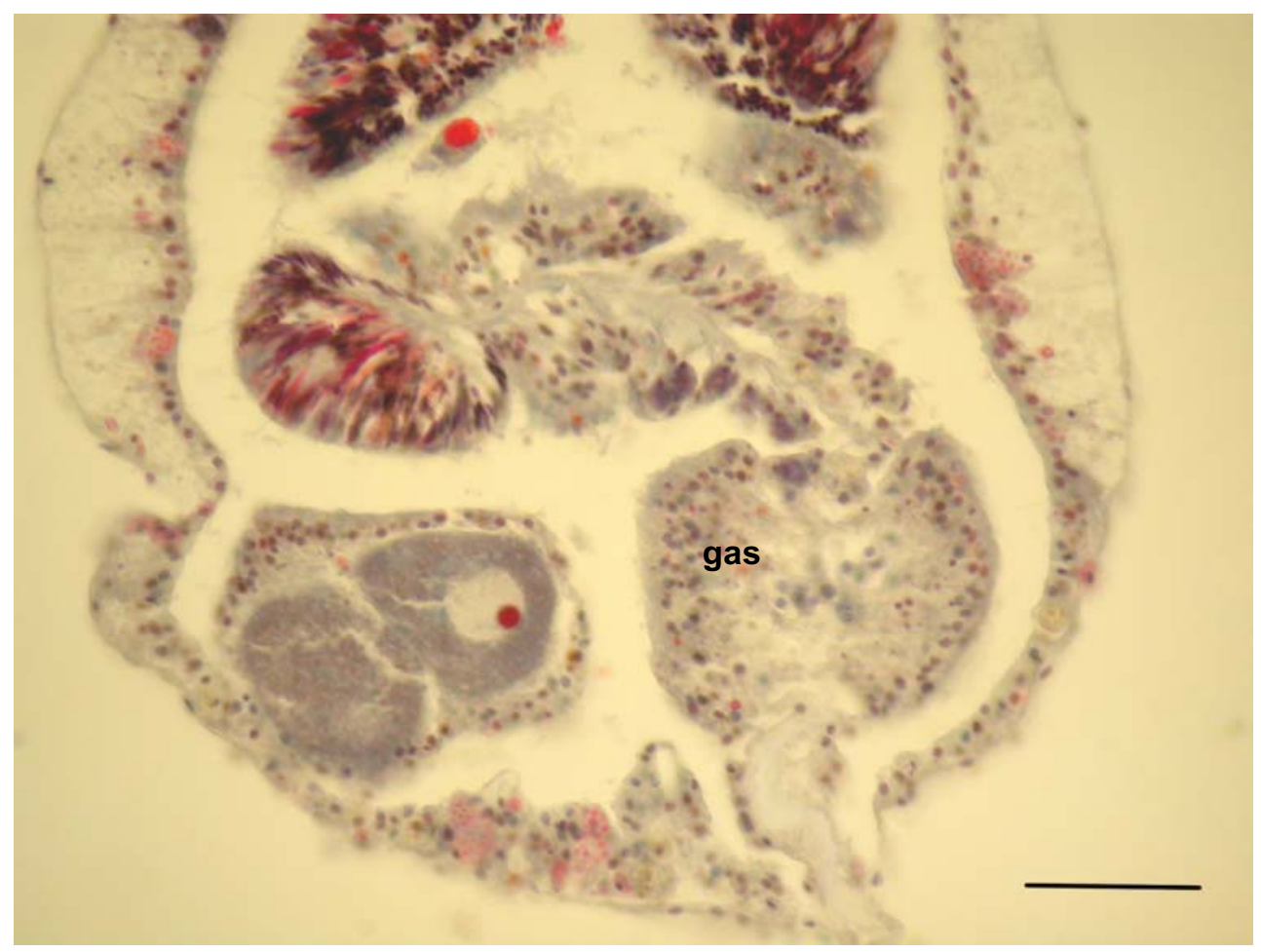

Figura 11: Mesentério masculino com espessamento da gastroderme (gas) na

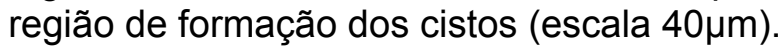


Foi possível observar um padrão geral no posicionamento dos gametas em relação ao pólipo. Os ovócitos, geralmente localizavam-se ligeiramente acima dos espermatócitos, mais próximos à região oral. Assim, ao longo da seqüência dos cortes transversais dos pólipos, os ovócitos sempre apareciam antes dos cistos, e esses, por sua vez, apareciam sozinhos na porção mais aboral do pólipo.

\subsection{Estágios da gametogênese}

Com base nos trabalhos de Szmant-Froelich et al. $(1980,1985)$ e Glynn et al. (1994), foram definidos três estágios de desenvolvimento para os ovócitos e quatro para os cistos espermáticos.

O estágio de ovogônia foi o mais difícil de ser distinguido, por não apresentar nenhuma característica de coloração mais evidente que pudesse diferenciá-lo das células intersticiais abundantes na endoderme. Para a determinação da ovogônia, utilizou-se além das características morfológicas descritas a seguir, a localização dessas células no mesentério. Elas foram observadas geralmente entre a endoderme e a mesogléia, em pequenos números de uma até duas células (apesar de termos registrado até dez num único mesentério). Na quantificação e caracterização do estágio I, incluiu-se a célula precursora da gametogênese (ovogônia) e o primeiro estágio de desenvolvimento da ovogênese (ovócito I).

Os estágios seguintes puderam ser facilmente detectados nos cortes por ter um tamanho maior, contornos mais bem definidos e uma coloração azulada típica. Ao longo do desenvolvimento dos ovócitos, a razão entre núcleo/citoplasma foi diminuindo gradualmente à medida que o citoplasma foi se desenvolvendo (ovócito I: 0,73 \pm

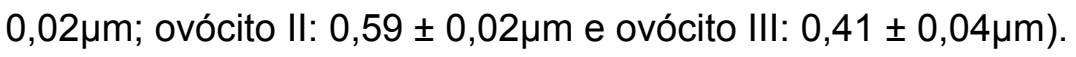

\subsubsection{Estágios da ovogênese:}

Estágio I: Ovogônias com núcleo relativamente grande, transparente ou de coloração azul clara, citoplasma e nucléolo de difícil visualização. Ovócito I visível próximo ou ancorado à mesogléia, com núcleo azul claro, citoplasma azul mais escuro e nucléolo vermelho, ambos visíveis. Células de 2,1 até 6,75 $\mu \mathrm{m}$ de diâmetro (Figura 13A).

Estágio II: Ovócito de 4,5 até 13,5 $\mu \mathrm{m}$ de diâmetro, de formato esférico ou elíptico, com citoplasma mais desenvolvido de coloração azul, núcleo relativamente grande centralizado, e nucléolo vermelho ou laranja (Figura 13B). 
Estágio III: Ovócito com formato elíptico ou em forma de "gota", citoplasma bastante desenvolvido de coloração azul ou cinza, presença de vesículas de lipídio, núcleo localizado no centro da célula, nucléolo bastante evidente de coloração rosa. Em estágio mais avançado, observam-se muitos grânulos de vitelo no citoplasma, e este torna-se mais acinzentado, e muitas vezes com aspecto "rachado". Células de 11,1 até 108,75 um de diâmetro (Figura 13C).

O estágio maduro da ovogênese (IV) não foi caracterizado, pois não foi possível detectar um conjunto de características que definisse esse estágio de forma precisa. Os ovócitos que aparentavam estar mais maduros exibiam características de coloração e posicionamento do núcleo muito semelhantes aos dos ovócitos III. Por isso, optou-se por classificar a ovogênese até o estágio III, que engloba ovócitos nesse estágio e, possivelmente, ovócitos IV, mas que não puderam ser seguramente distinguidos (Figura 13D).

Alguns ovócitos III apresentaram características de coloração distintas das descritas acima, como por exemplo, um citoplasma e um núcleo corados fortemente de laranja ou vermelho, ou então, um núcleo de coloração bem azul (mais forte que o citoplasma). Apesar das características distintas de coloração, não se tratavam de ovócitos maduros (estágio IV), pois possuíam um tamanho relativamente pequeno, sendo considerados, portanto, como uma variação no padrão de coloração dos ovócitos III.

Ao contrário das ovogônias, as espermatogônias puderam ser melhor distinguidas das células intersticiais, por estarem agrupadas em ninhos envolvidos por uma camada frouxa de mesogléia, sendo sua distinção relativamente fácil.

À medida que os cistos foram se desenvolvendo a camada que os delimitava foi se tornando mais definida, o número de espermatócitos foi aumentando e se concentrando principalmente na periferia do cisto, com cada vez menos espermatócitos no centro, até enfim, a distinção de um lúmen nos últimos estágios. A coloração das células foi mudando, passando de um azul mais claro (nos primeiros estágios) para um azul mais escuro, marrom, laranja e vinho, isto é, foram desenvolvendo uma maior afinidade à hematoxilina, uma provável indicação da condensação do ácido nucléico. Mudanças no tamanho dos espermatócitos foram praticamente imperceptíveis. O estágio de 


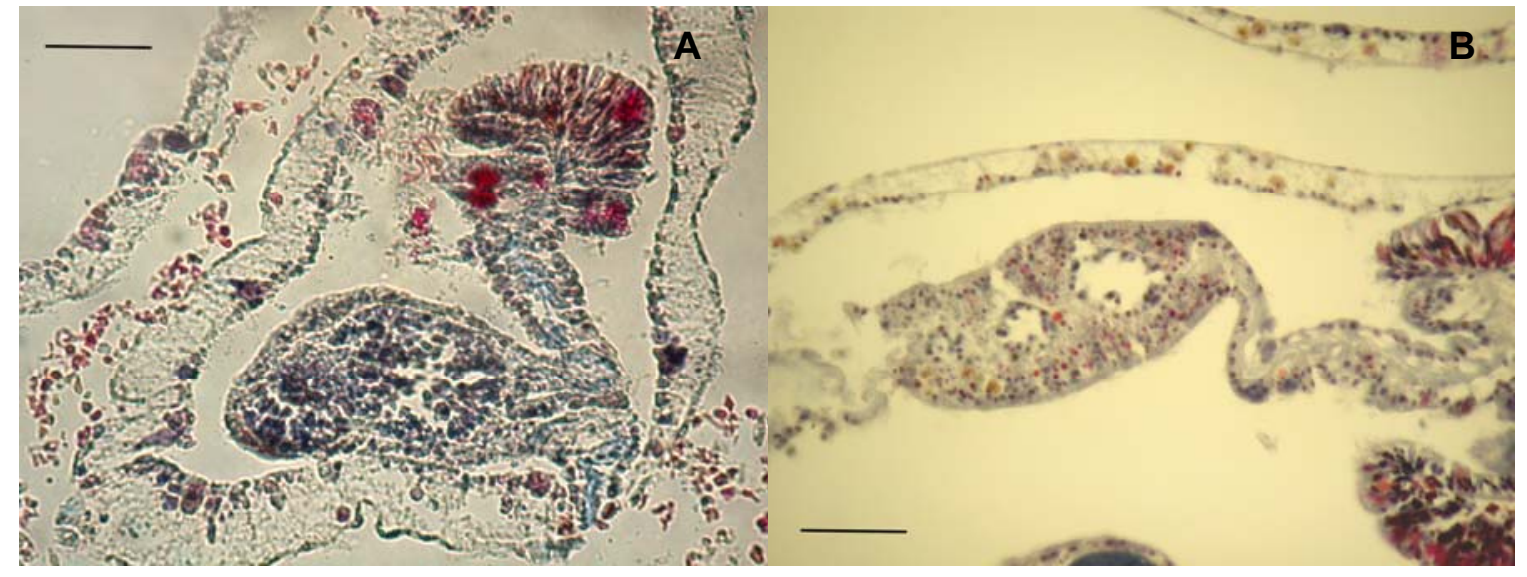

Figura 12: A - Corte transversal com cisto posicionado lateralmente ao mesentério, e $B$ - dentro do mesentério (padrão mais encontrado) (escala 40 $\mu \mathrm{m}$ ).

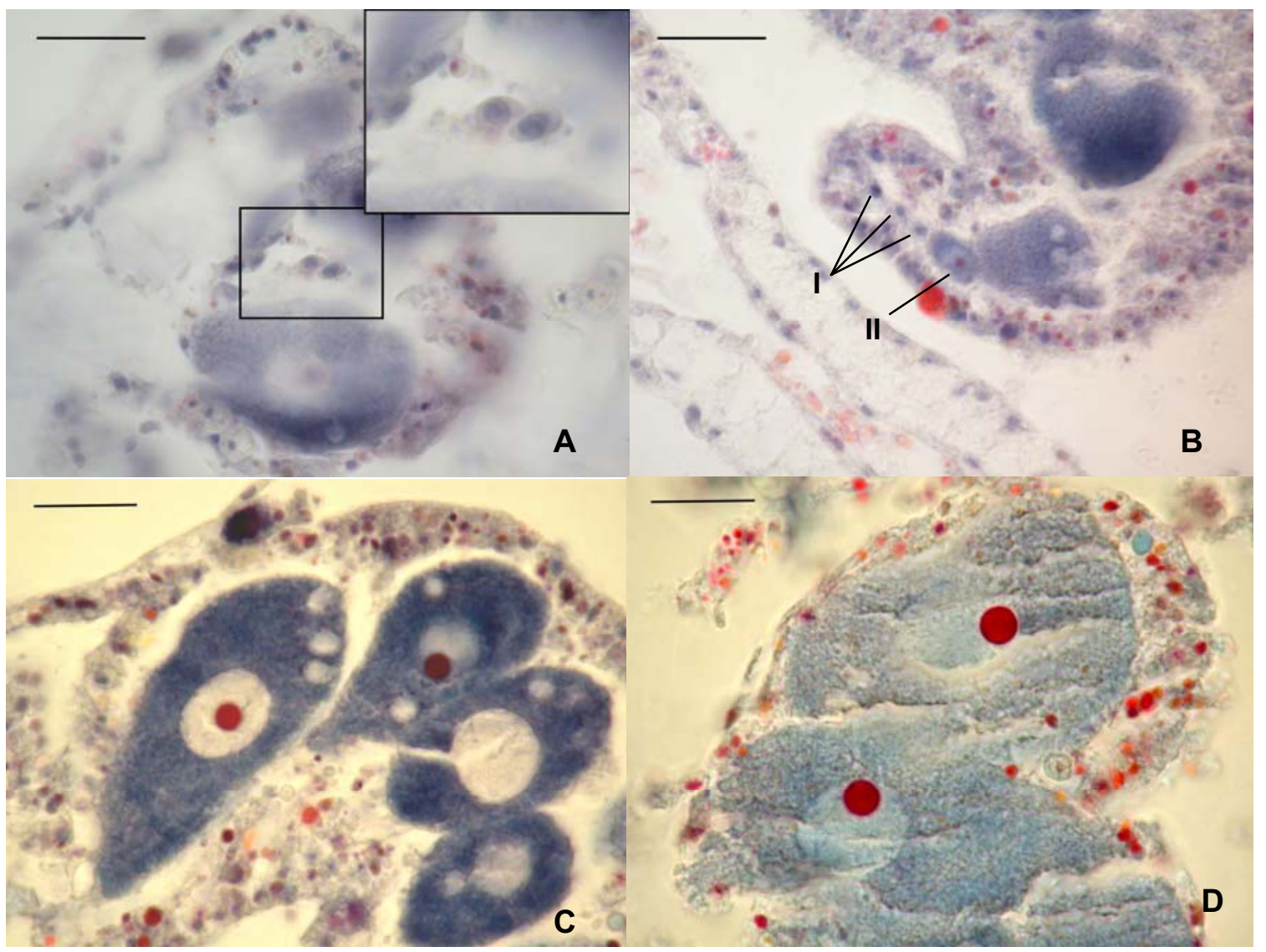

Figura 13: Estágios da ovogênese: A - estágio I: ovogônias ; B - estágios I: ovócitos I e estágio II; C - estágio III e D - ovócito III com maior diâmetro encontrado, citoplasma com aspecto "rachado", porém com núcleo ainda bastante centralizado (escala $20 \mu \mathrm{m}$ ). 
espermátide (quando é completada a última divisão meiótica e as células reduzem seu tamanho pela metade) não foi distinguido. A redução do tamanho ficou evidente apenas no estágio de espermatozóide (estágio IV). Este, porém, foi observado em apenas 31 dos mais de 1800 pólipos analisados.

\subsubsection{Estágios da espermatogênese:}

Estágio I: Espermatogônias de 2,4 até 4,8 $\mu \mathrm{m}$ de diâmetro, com núcleo relativamente grande, de forma elipsoidal, de coloração azul clara, arranjadas em ninhos sem formato definido de até $36 \mu \mathrm{m}$ de diâmetro e formados por até 35 células envolvidas por uma camada pouca definida de mesogléia (Figura 14A). Espermatócitos I com tamanho e coloração semelhantes às espermatogônias, formando cistos com contorno mais bem definido (Figura 14B).

Estágio II: Espermatócitos com mesmo tamanho e formato do estágio I, de coloração azul ou cinza e de formato arredondado. Cistos bem definidos por uma fina camada de mesogléia, apresentando aspecto vacuolado ("buracos") com região central pouco preenchida por espermatócitos. Diâmetro máximo de 47,25 ㅆm (Figura 14C-D).

Estágio III: Cistos de tamanho maior e formato mais alongado, elíptico, formados por espermatócitos de coloração azul escuro, vinho, marrom ou laranja, distribuídos mais na periferia do cisto. Lúmen presente. Diâmetro máximo de $107 \mu \mathrm{m}$ (Figura 14E).

Estágio IV: Cistos com espermatozóides de tamanho bastante reduzido e de coloração vinho, cauda azul claro. Padrões típicos de "buquês" foram, ocasionalmente, observados (Figura 14F).

A detecção dos espermatozóides levou algum tempo até percebermos que os pontos de coloração vinho que víamos espalhados no mesentério se tratavam, na verdade, de espermatozóides, e não de algum produto de células secretoras ou artefato da coloração (Figura 14G). Os típicos formatos de "buquês", onde se observam as caudas formando o "cabo" dessa estrutura, foram vistos apenas em alguns cortes.

Nem todos os ovócitos pareceram tornar-se maduros. Em muitos cortes foram observados ovócitos que estavam sendo absorvidos por outros, pois muitas vezes não se distinguia o limite de um e de outro, como se estivessem fundindo entre si. Em outros casos, ovócitos aparentavam estarem degenerando e sendo absorvidos pelo pólipo (Figura 15). 


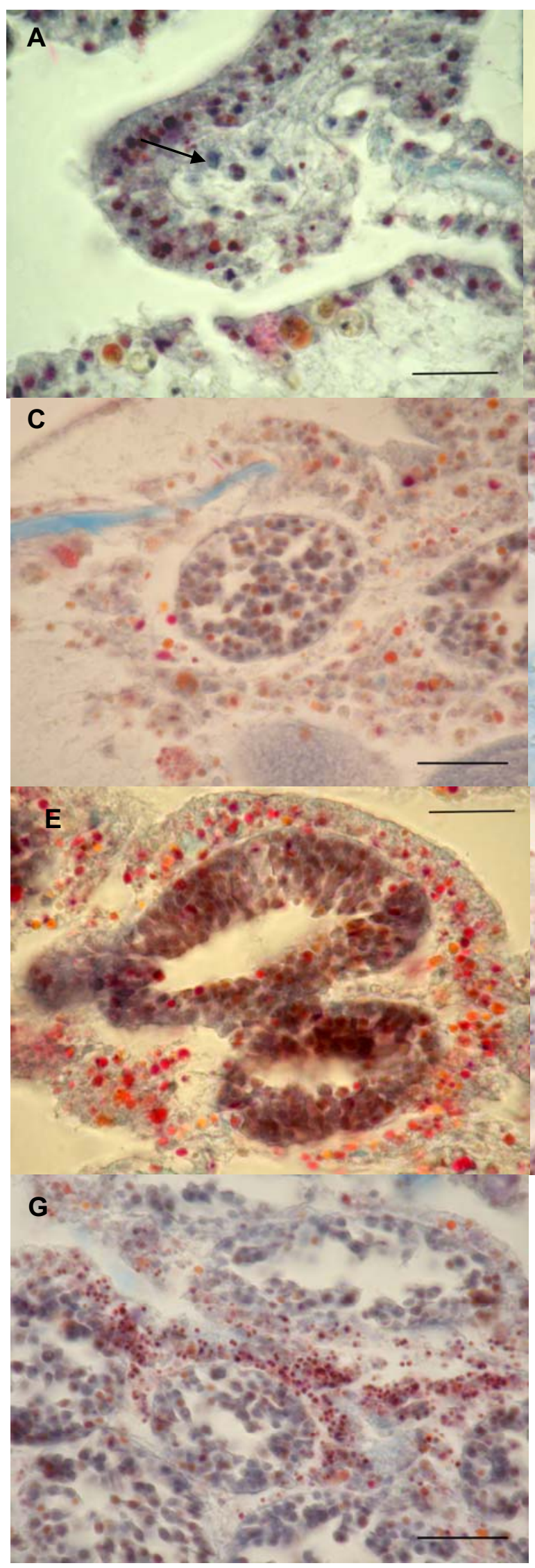

B
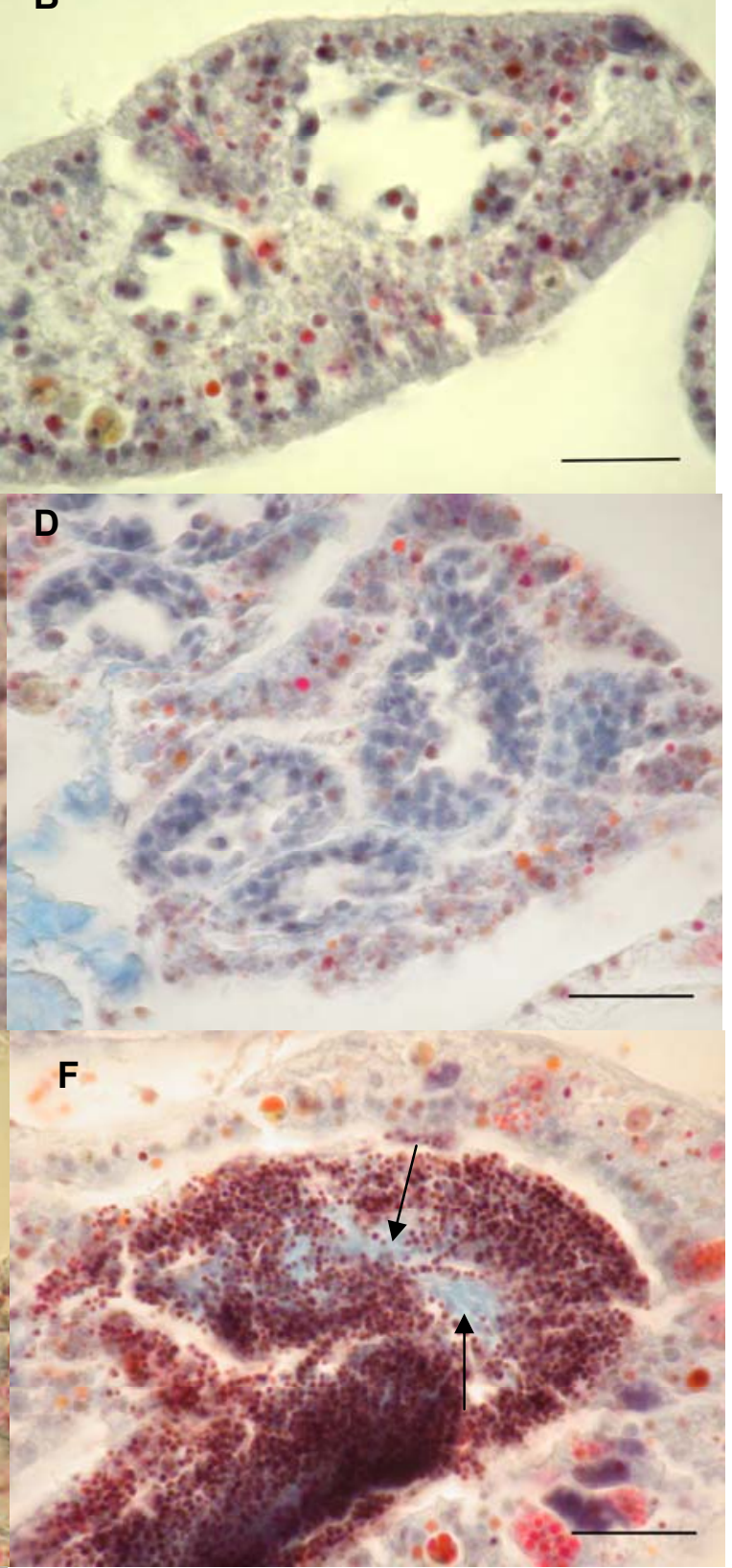

Figura 14: Estágios da espermatogênese: A - estágio I: ninho de ovogônias (seta); B espermatócitos I; C - estágio II: inicial; D maduro; $\mathrm{E}$ - estágio III, lúmen bastante evidente ; F - estágio IV: espermatozóides com caudas azuis em formato de buquê (setas); G - espermatozóides espalhados entre as células da gastroderme e mesogléia

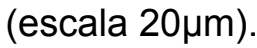




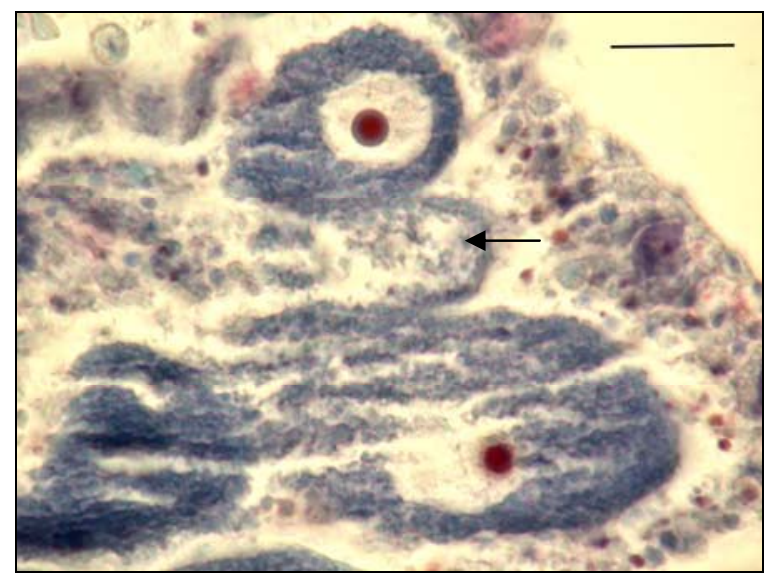

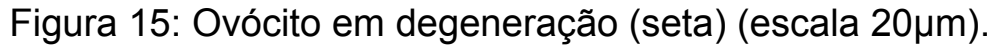

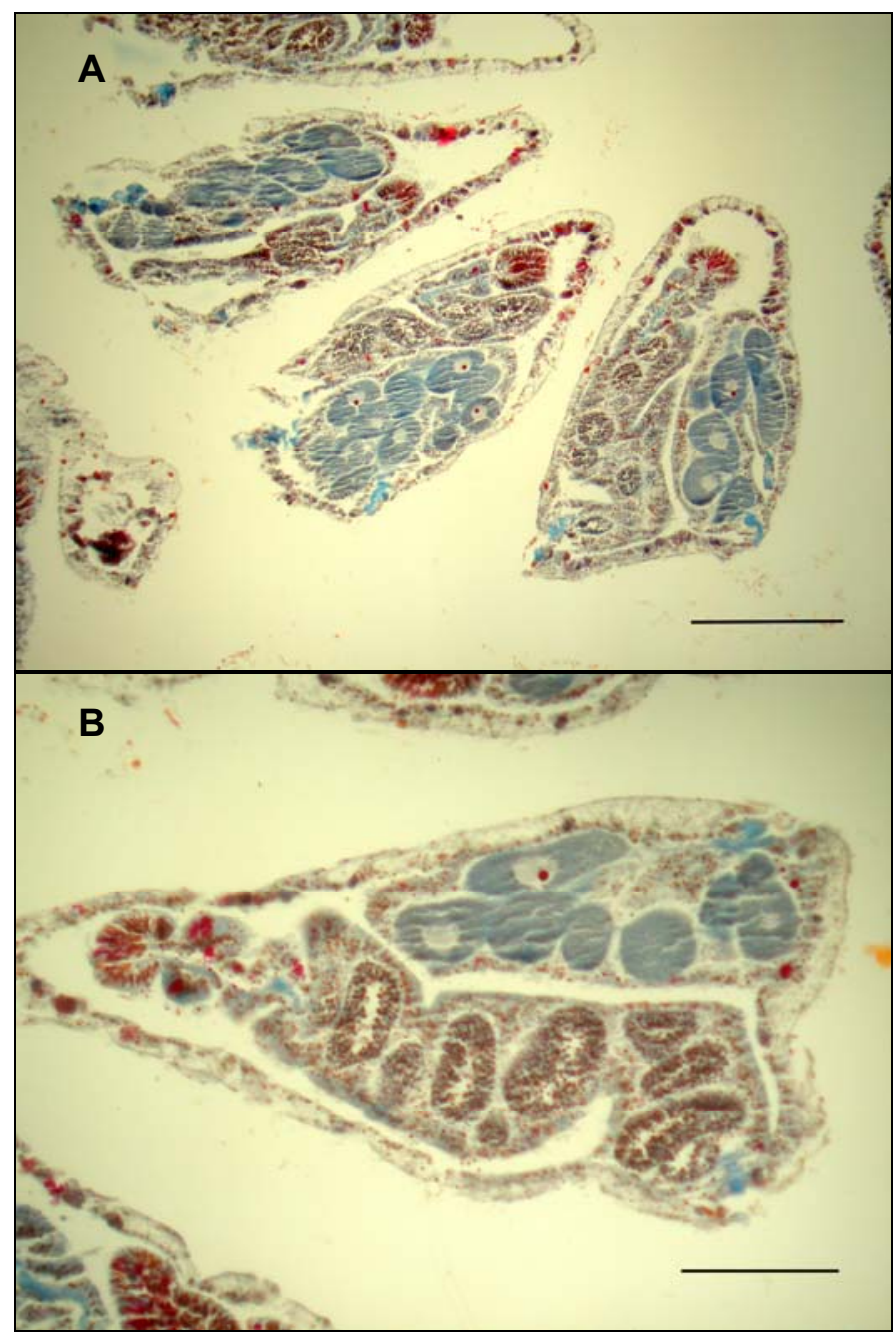

Figura 16: A - Lóculos gástricos quase totalmente preenchidos pelos gametas (escala $200 \mu \mathrm{m}$ ); B - detalhe de um lóculo (escala $100 \mu \mathrm{m}$ ). 
Observou-se nos cortes transversais que, quando os pólipos se encontravam no período máximo de fertilidade (contendo numerosos ovócitos e cistos espermáticos de tamanho grande), os lóculos gástricos (cavidade gastrovascular) ficavam quase que totalmente ocupados pelos gametas (Figura 16A-B ), chegando a ter até 18 ovócitos e 9 cistos por mesentério. Nenhum embrião ou nenhuma plânula foi encontrado nos mais de 1800 pólipos analisados.

\subsection{Ciclo Reprodutivo}

\subsubsection{Ovogênese}

O ciclo reprodutivo de Madracis decactis tem duração de cerca de sete meses. Os primeiros ovócitos foram encontrados em outubro tanto em 2004 como em 2005. Em 2005, a intensidade da produção de ovócitos I parece ter sido mais constante, e talvez o desenvolvimento dos ovócitos tenha ocorrido mais lentamente, já que não observamos ovócitos III até dezembro desse ano (Figura 17).

Praticamente todos os estágios foram encontrados simultaneamente nas colônias durante o ciclo reprodutivo, indicando uma produção contínua. A proporção do ovócito III encontrada nas colônias foi sempre superior às dos demais estágios (exceto no início do ciclo de 2005), e o desenvolvimento desse estágio deve ser mais prolongado que os estágios iniciais (Figura 17). No final do ciclo (abril), observamos apenas ovócitos III, caracterizando uma sincronização da fase final de amadurecimento das células reprodutivas.

O pico da atividade reprodutiva acontece entre fevereiro e abril, quando observamos a maior porcentagem de ovócitos de todos os estágios analisados nas coletas, isto é, $48-75 \%$ dos ovócitos I, 49-71\% dos ovócitos II e 59-95\% dos ovócitos III. A quantidade de ovócitos I e II nas colônias entre fevereiro e março é grande (>48\%), indicando que a formação de novos ovócitos não só persiste como tem seu pico nesse período (Figura 18).

Ao longo do ciclo reprodutivo, houve um aumento progressivo no número de pólipos com ovócitos II e III (Figura 19). É interessante destacar que, de dezembro de 2004 a fevereiro do ano seguinte, houve um aumento de três vezes no número de pólipos com ovócitos III, enquanto que em dezembro de 2005 não foram observados pólipos com ovócitos III, apesar de na coleta seguinte (março de 2006) 74\% dos pólipos conterem 
23-out-04

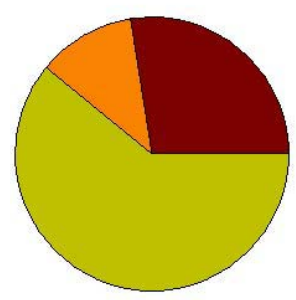

01-out-05

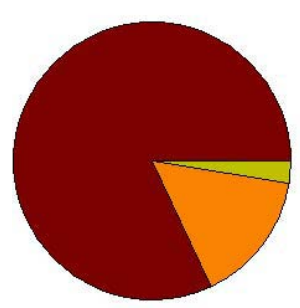

12-dez-04

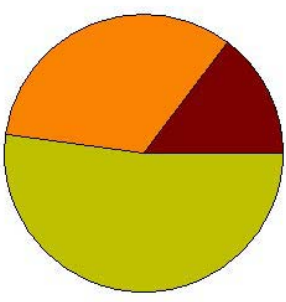

03-dez-05

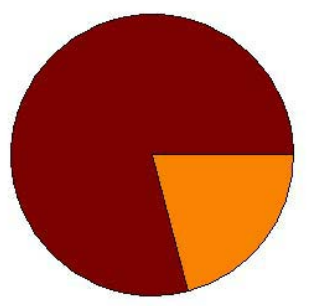

26-fev-05

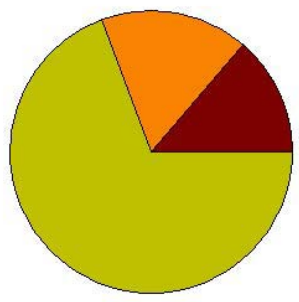

18-mar-06

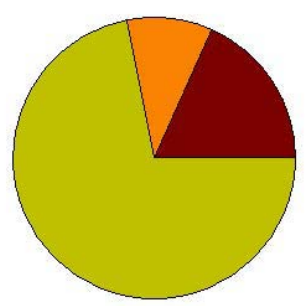

30-abr-05

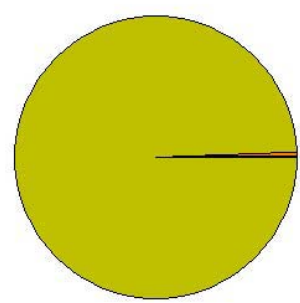

20-mai-06 *

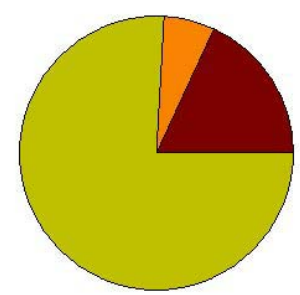

Figura 17: Freqüência dos estágios dos ovócitos por coleta (as coletas dos dias 28-ago-04 e 23-jul-05 não continham ovócitos).* Amostra com apenas uma colônia fértil.

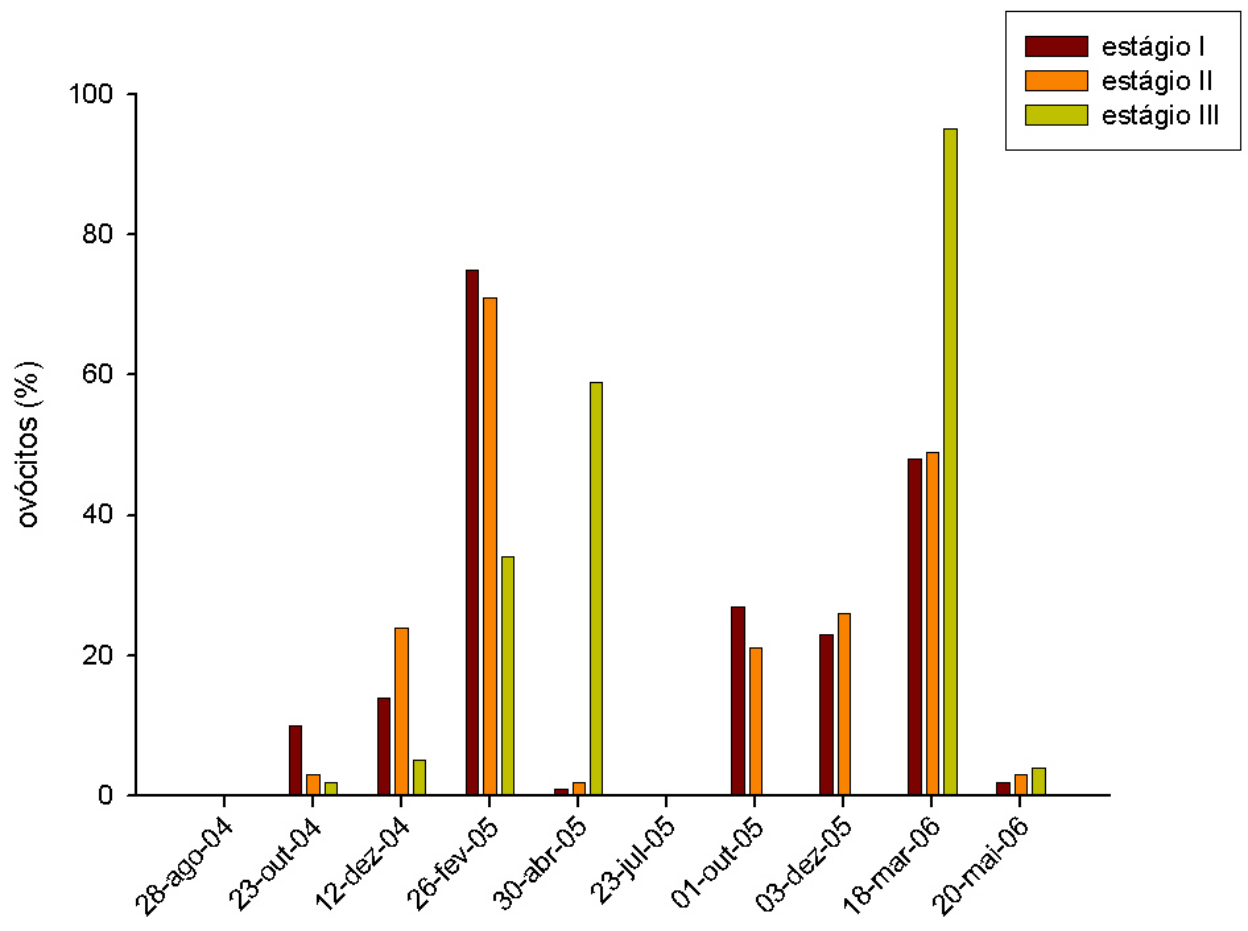

Figura 18: Freqüências dos estágios dos ovócitos/soma total de cada estágio de 23/10/04 até 30/04/05 e 01/10/05 até 20/05/06. 


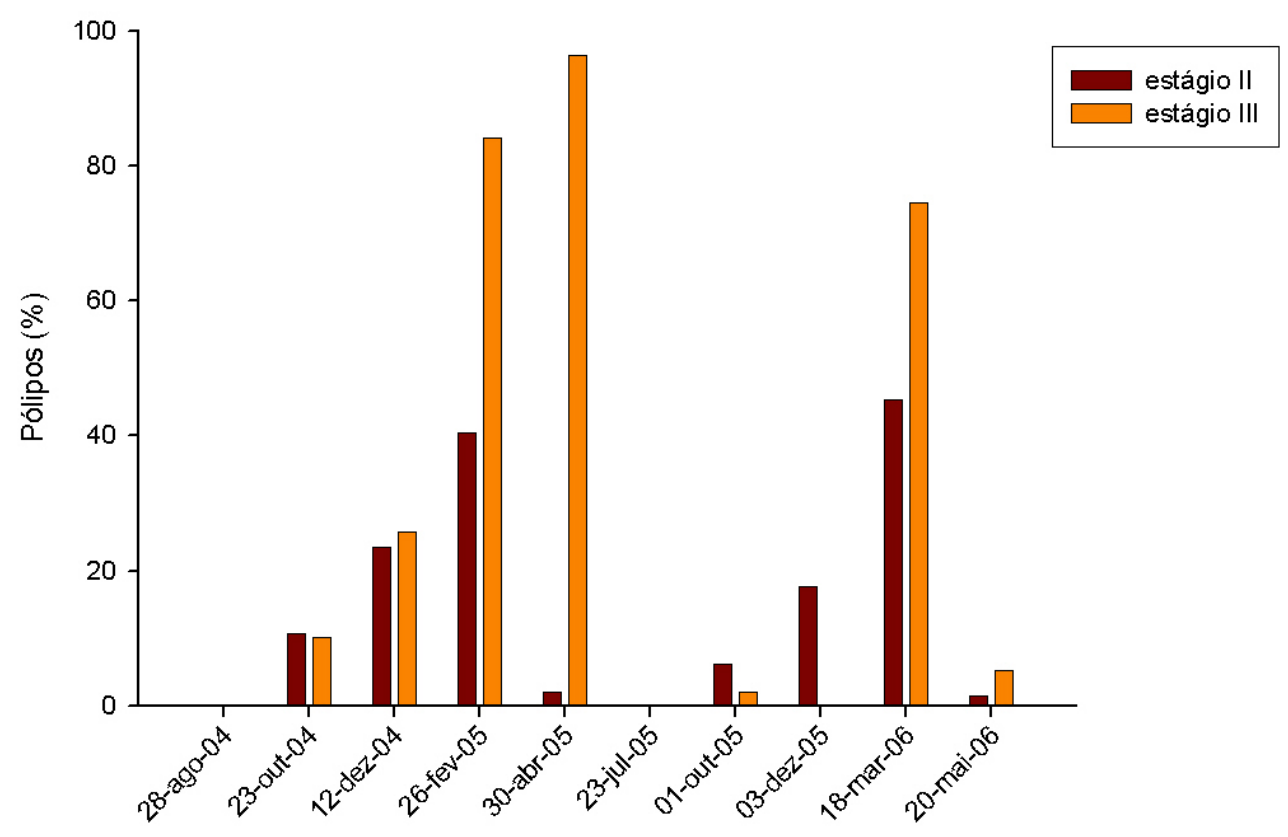

Figura 19: Porcentagem de pólipos/coleta com ovócitos II e III (como o mesmo pólipo pode conter ovócitos em estágios diferentes a soma das porcentagens pode exceder $100 \%$ ).

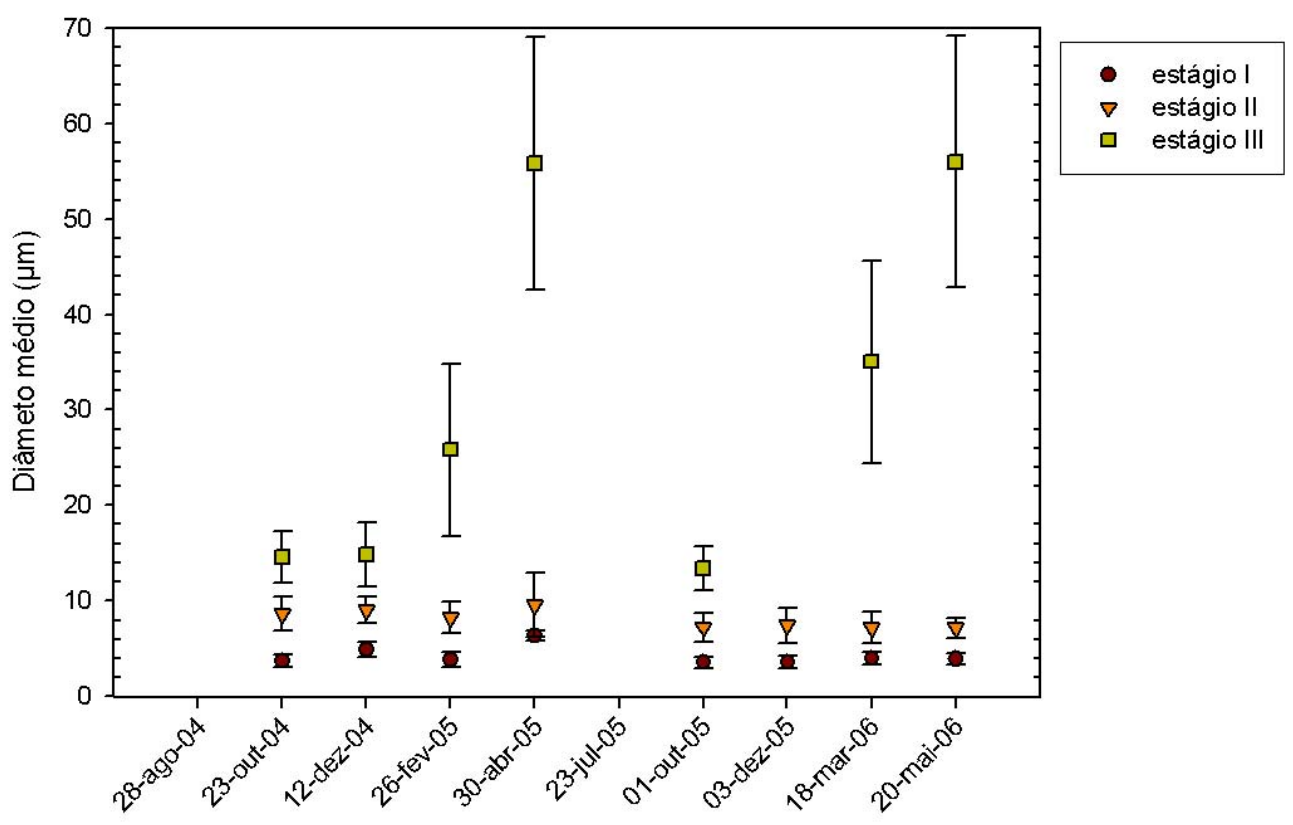

Figura 20: Diâmetro médio dos ovócitos (barras: desvio padrão). 
ovócitos nesse estágio. Esses resultados sugerem que, provavelmente, de dezembro até fevereiro/março aconteça o pico da atividade de vitelogênese no ciclo reprodutivo. Em abril de 2005, 96,4\% dos pólipos analisados continham ovócitos III. Assim, podese dizer que no final do ciclo a colônia inteira deve tornar-se fértil. Nenhum ovócito foi encontrado na coleta seguinte (julho), e em maio de 2006, apenas uma colônia apresentava-se fértil, todas as demais não continham ovócitos.

O desenvolvimento dos ovócitos também pode ser acompanhado através do tamanho do diâmetro médio dessas células (Figura 20). Os ovócitos I e II permaneceram com o diâmetro médio constante ao longo do ciclo (ovócito I: 3,5 -

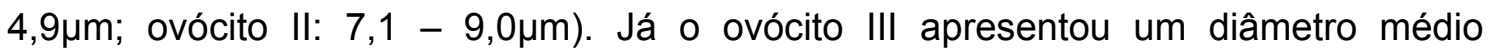
constante no início do ciclo $(13,4-14,8 \mu \mathrm{m})$, mas apresentou um aumento de até quatro vezes nos últimos três meses do ciclo, atingindo o valor máximo de 55,9 $\mu \mathrm{m}$ em maio, corroborando a idéia de que nesse período ocorre uma intensa atividade reprodutiva de $M$. decactis, ou seja, não só a produção de ovócitos é maior, como o amadurecimento dessas células é mais intenso.

\subsubsection{Espermatogênese}

A espermatogênese é mais curta que a ovogênese e tem duração de, aproximadamente, três meses (Figura 21). Os primeiros cistos espermáticos foram observados em fevereiro de 2005. O maior número de cistos II, III e IV foi encontrado em abril, em sincronia com o pico da ovogênese. Apenas nesse mês foram observados cistos espermáticos IV, com espermatozóides prontos para serem liberados, e espaços vazios no mesentério masculino parecendo buracos deixados pela liberação dos cistos maduros (Figura 22). Como na coleta seguinte (20 maio de 2005) nenhuma colônia, exceto uma, estava fértil, podemos supor que a liberação dos espermatozóides, fertilização dos ovócitos e a liberação das plânulas devam ocorrer entre o final de abril até o meio de maio. Além do ciclo ser mais curto, a formação de cistos acontece apenas no início (fevereiro/março), por isso a maturação dos espermatócitos ocorre de forma mais sincronizada, diferentemente da ovogênese.

\subsection{Parâmetros ambientais}

Os dados da temperatura média anual da superfície da água do mar dos últimos 21 anos próximo ao local de estudo mostraram que até 2000 a temperatura média anual não havia excedido os $24^{\circ} \mathrm{C}$, oscilando entre $22,7^{\circ} \mathrm{C}$ em 1997 , e $23,9^{\circ} \mathrm{C}$ no ano seguinte. A partir de 2001 , a temperatura média atingiu $24^{\circ} \mathrm{C}$, e notou-se um aumento progressivo 

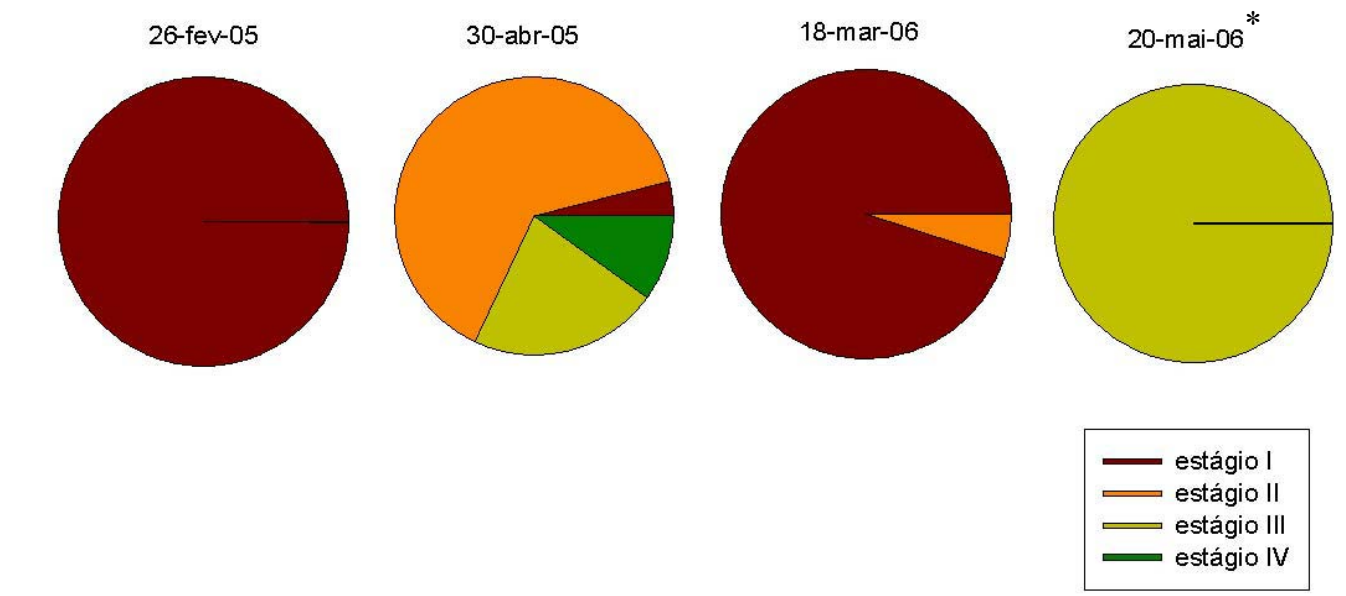

Figura 21: Freqüência dos estágios nos cistos espermáticos/total de cada coleta. * Amostra com apenas uma colônia fértil. 


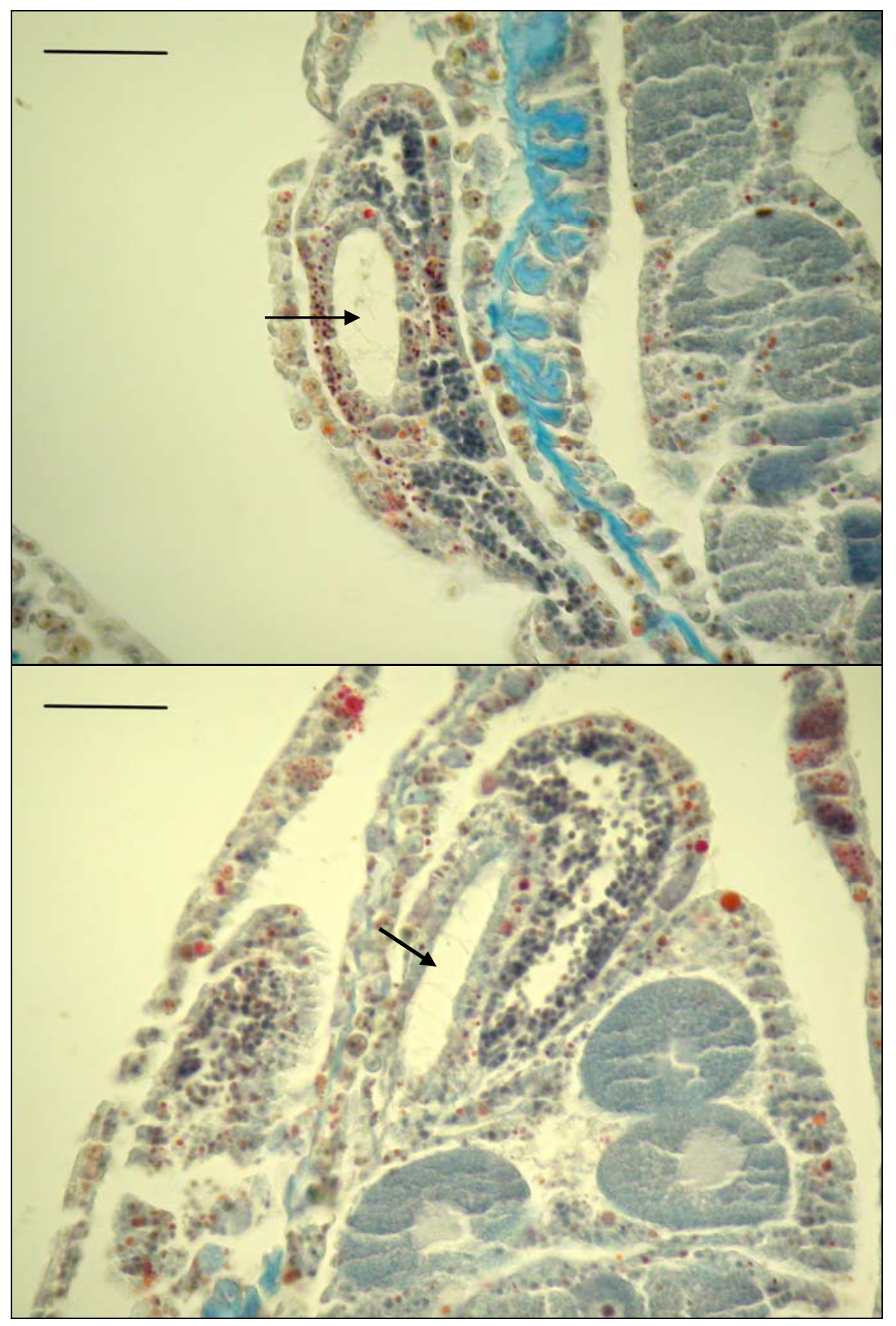

Figura 22: Buracos deixados nos mesentérios masculinos pela liberação dos cistos espermáticos maduros (setas) (coleta de 30/04/05) (escala 40 $\mu \mathrm{m}$ ). 
até 2003, quando registrou-se a maior temperatura média dos últimos 21 anos (24, $5^{\circ} \mathrm{C}$ ). Em 2004, porém, a temperatura caiu novamente para a casa dos $23^{\circ} \mathrm{C}$, voltando a subir em $2005\left(24,1^{\circ} \mathrm{C}\right)$ (Figura 23). A variação máxima anual da temperatura da água foi de $11,4^{\circ} \mathrm{C}$ em 2006 (mínima de 17,4 em outubro e máxima de $28,8^{\circ} \mathrm{C}$ em março) (Figura 24).

Os dados de irradiação solar média mensal do Atlas Solarimétrico do Brasil referentes à um ano amostral (1989) apresentaram um padrão bastante similar com os dados fornecidos pela NASA referentes ao período de 10 anos (198-1993) (dados não apresentados). De modo geral, a irradiação solar média mensal tem seus maiores valores entre novembro e março. A partir de abril a irradiação média diminui bastante e atinge seus menores valores em maio, junho e julho. Em agosto ela começa a aumentar e atinge seus valores máximos no verão (janeiro e fevereiro). Em relação ao padrão mensal da temperatura, nota-se que durante a primavera a temperatura média mensal tem um aumento gradual indo de $21,3^{\circ} \mathrm{C}$ em setembro para $22,7^{\circ} \mathrm{C}$ em novembro. No verão observamos as maiores temperaturas médias com o valor máximo em fevereiro $\left(26^{\circ} \mathrm{C}\right)$, em seguida, no outono (março/abril/maio) a temperatura começa a cair, até atingir $21,4^{\circ} \mathrm{C}$ em agosto, voltando a subir em outubro (Figura 25). Como a água leva mais tempo para aquecer e esfriar (devido ao seu alto calor específico), a diferença entre os picos máximo e mínimo da irradiação solar e da temperatura superficial da água é de cerca de 1 até 2 meses (Figura 25).

Os trabalhos de Soares et al. (2005) e Soares (2005) forneceram as informações da distribuição espacial da precipitação na região hidrográfica da Baía de Ilha Grande. Segundo os autores, o litoral sul fluminense possui um alto índice pluviométrico com distribuição espacial irregular da chuva, influenciada pela disposição do relevo. As regiões mais chuvosas estão a barlavento e próximas ao litoral, enquanto que as de menor precipitação estão a sotavento ou à medida que se distancia do litoral. A região mais chuvosa fica entre Bracuí, Angra dos Reis, e São Roque, Parati. No período úmido, que se estende de outubro à março, a média anual ultrapassa $1500 \mathrm{~mm}$, enquanto que no período seco, que se estende de abril à setembro, a área continua com os índices pluviométricos elevados, alcançando $800 \mathrm{~mm}$. Dentre os possíveis fatores que influenciam na distribuição espacial diferenciada, como altitude, orientação de vertentes, declividade e distância do litoral, esta última foi a que apresentou maior correlação, evidenciando a forte influência das frentes frias marinhas na região.

Os autores definiram um padrão geral da precipitação para a região: o trimestre mais chuvoso é o de dezembro, janeiro e fevereiro; no trimestre seguinte (março, abril e 


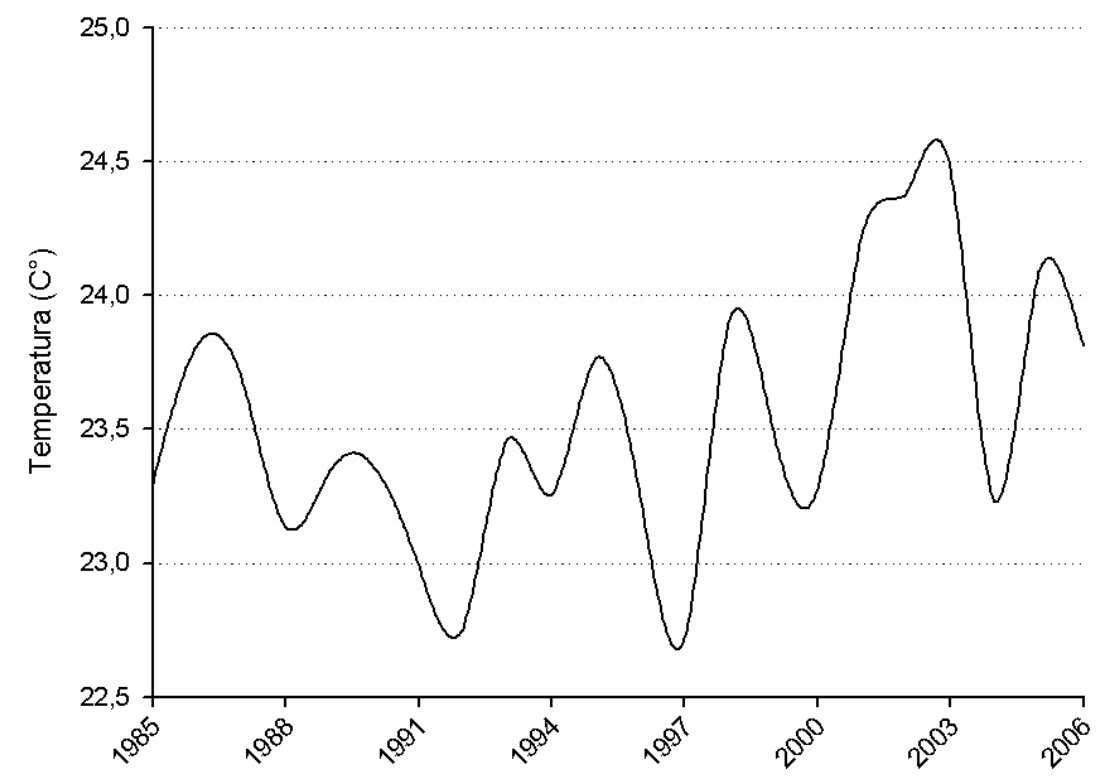

Figura 23: Temperatura superficial do mar média da região $23^{\circ} 1^{\prime} \mathrm{S}, 43^{\circ} 9^{\prime} \mathrm{W}$ (NOMADS LAS Server - NOAA).

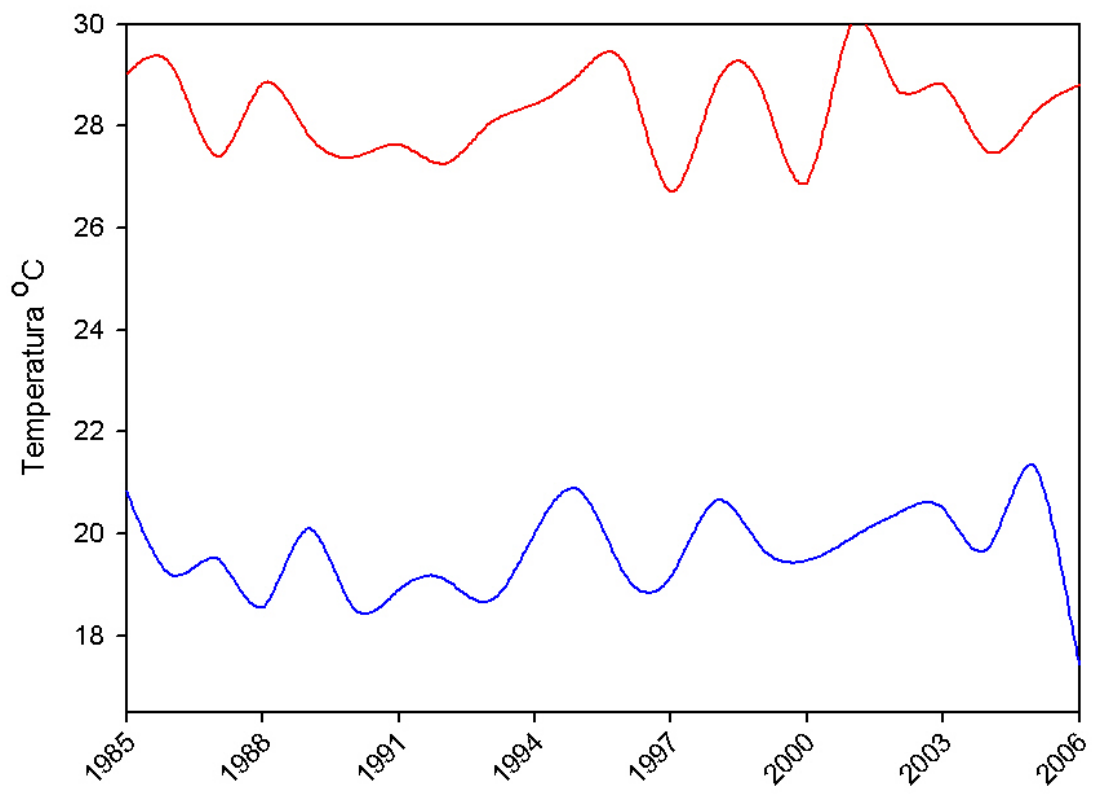

Figura 24: Temperaturas máxima e mínima anual da região $23^{\circ} 1^{\prime} \mathrm{S}, 43^{\circ} 9^{\prime} \mathrm{W}$ (NOMADS LAS Server - NOAA). 


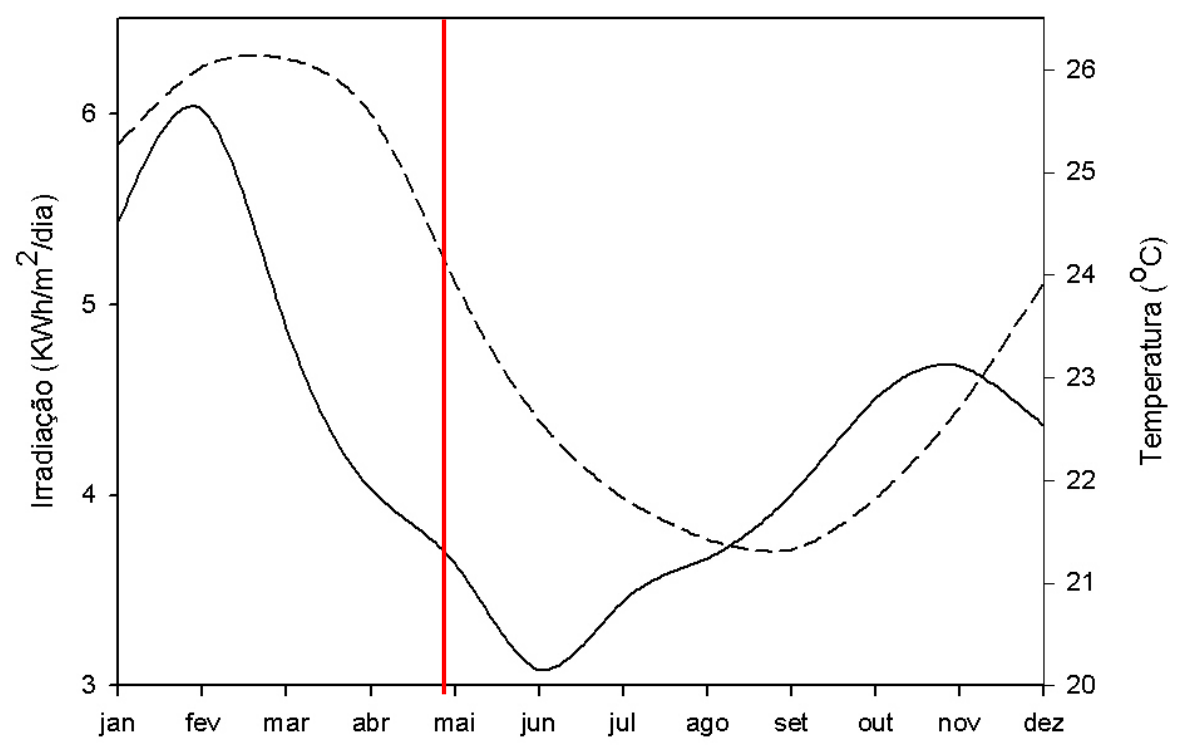

Figura 25: Irradiação solar média mensal (linha sólida) de 1989 (Atlas Solarimétrico do Brasil, 2000), temperatura superficial do mar média mensal de 1985-2006 (linha pontilhada) (NOMADS LAS Server - NOAA) e provável período de liberação das plânulas (linha vermelha).

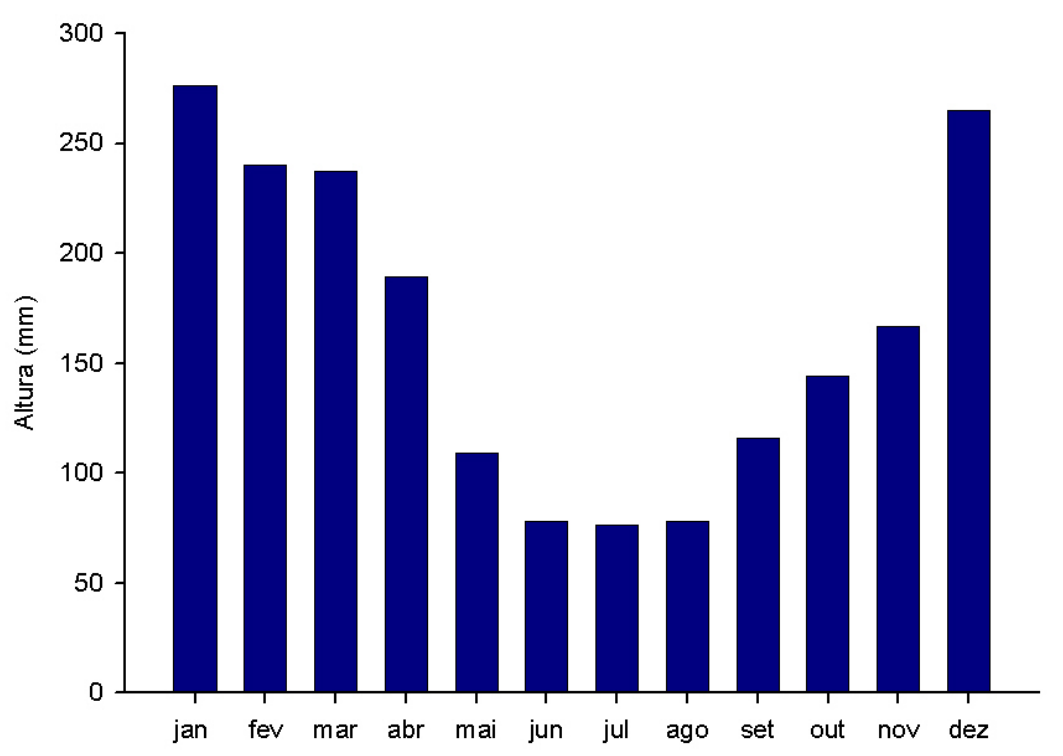

Figura 26: Precipitação média mensal, estação de Angra dos Reis de 19611990 (INMET). 
maio) ocorre um decréscimo significativo das chuvas, caracterizando-se como um período de transição entre os meses mais úmidos e os mais secos; em junho, julho e agosto os índices pluviométricos têm uma queda significativa e são registrados os menores índices pluviométricos do ano; e finalmente, os meses de setembro, outubro e novembro são novamente meses de transição. Dados adicionais obtidos no Plano de Manejo do Parque Nacional da Serra da Bocaina corroboram os dados de Soares et al. (2005), e indicam que os maiores índices pluviométricos se encontram no litoral, vertente oceânica e planalto da Bocaina (Figura 26). 


\section{5 - DISCUSSÃO}

\subsection{Fragmentação}

Um grande número de espécies parece estar adaptado à fragmentação e incorpora esse processo na sua história de vida (Highsmith, 1982). Apesar das formas ramificadas terem um potencial de fragmentação maior devido ao seu rápido crescimento e a facilidade de quebra de seus ramos (Bak \& Engel, 1979), a morfologia das espécies que fragmentam abrange muitas formas de crescimento, desde formas ramificadas e delicadas, até colônias maciças e largas (Highsmith, 1982), como por exemplo, as muitas colônias pequenas de Montastrea annularis encontradas nos recifes de Porto Rico, que foram derivadas da fragmentação de colônias grandes através da morte parcial de seus tecidos (Szmant, 1991). Estudos eletroforéticos de populações de corais revelaram estruturas de populações altamente clonadas para muitas espécies examinadas e é geralmente assumido que esse tipo de estrutura reflita o processo de fragmentação (Willis 1990). A reprodução assexuada através da fragmentação parece ser a maior fonte de recrutas das populações de Pavona cactus em Eclipse Island, Austrália, e estudos prévios com essa espécie revelaram altas taxas de sobrevivência de fragmentos criados artificialmente (Willis, 1985; Willis \& Ayre, 1985), apesar disso não significar que a reprodução assexuada seja a única fonte de recrutas dessa população (Ayre \& Willis, 1988).

Ao contrário dos outros trabalhos sobre a reprodução de Madracis decactis no Caribe (Vermeij et al., 2003b) e no Brasil (Castro \& Pires, 2006) que coletaram fragmentos extraídos a partir de colônias fixadas, o presente trabalho utilizou fragmentos que já se encontravam soltos sobre o substrato. Esses fragmentos encontrados na llha Imboassica indicam que nesse local, a espécie deva sofrer o processo de fragmentação. Muitos fragmentos pequenos (com cerca de 5 até $7 \mathrm{~cm}$ de diâmetro) foram encontrados soltos, concentrados numa determinada área da ilha, muitas vezes junto com cascalho e corais mortos dessa mesma espécie. Nesse local, o costão tem uma declividade mais suave, além de muitas rochas pequenas que estão distribuídas sobre o fundo de material inconsolidado e mais fino, formando um ambiente mais favorável para o assentamento e fixação das plânulas, se comparado aos outros locais da ilha, onde observamos paredões mais íngremes e constituído de rochas maiores. Estudos sobre o comportamento do assentamento de plânulas de corais demonstraram que elas são capazes de escolher e discriminar os substratos quando confrontadas com uma ampla variedade deles, e que geralmente, dão preferência a microhabitats crípticos, formados por fendas e sulcos de substratos irregulares (Lewis, 1974; Harrison \& Wallace 1990; Baird et al., 2003). Assim, a configuração dessa região em particular, pode ter propiciado uma concentração maior 
de colônias fixadas, o que explicaria o grande número de fragmentos encontrados nesse local.

As colônias de $M$. decactis atingem um tamanho relativamente pequeno (máximo de $30 \mathrm{~cm}$ de diâmetro), sendo as colônias de 10 até $15 \mathrm{~cm}$ as mais comumente observadas. Done \& Potts (1992), sugeriram que a vulnerabilidade das colônias de Porites ao deslocamento por ondas variava ao longo de sua vida, à medida que a morfologia mudasse com o aumento do tamanho. As colônias mais vulneráveis seriam aquelas nem muito grandes (grande massa) nem muito pequenas (pequena área para serem arrastadas), isto é, colônias de tamanho intermediário, com distribuição de massa instável, e pouca ou nenhuma adesão ao substrato. A pouca freqüência de colônias com $30 \mathrm{~cm}$ de diâmetro talvez reflita a vulnerabilidade dessas colônias para a fragmentação.

Claramente as tempestades possuem um papel seletivo na evolução de corais capazes de sobreviver ao deslocamento e ainda capitalizar através da colonização por fragmentação (Highsmith, 1982). No inverno ocorrem ondas mais altas geradas pela atuação de ventos locais fortíssimos na Baía de llha Grande, e a entrada das maiores tempestades do ano (Ministério do Meio Ambiente, 2006). Esses eventos poderiam, então, favorecer a fragmentação das colônias, principalmente, durante o inverno.

O tamanho relativamente pequeno das colônias de $M$. decactis pode ser um dos fatores que contribuem para a geração de fragmentos pequenos. Entretanto, essa também é uma característica de outra espécie do mesmo gênero, Madracis mirabilis, que atinge tamanhos grandes, tem forma ramificada e delicada, e utiliza a fragmentação como principal meio de propagação nas águas rasas do Caribe (Bak \& Engel, 1979). Highsmith (1982) sugeriu que as espécies que se baseiam na fragmentação como principal forma de reprodução tenderiam a produzir fragmentos grandes, devido à alta mortalidade das colônias pequenas por causa do soterramento. As espécies que produziriam fragmentos menores e em grande quantidade, como $M$. mirabilis, tenderiam a ocorrer em habitats mais calmos, aumentando as chances de sobrevivência.

Apesar das tempestades e ventos fortes durante o inverno, o local de estudo é um lugar relativamente abrigado com águas calmas na maior parte do ano, tanto que é bastante utilizado nas atividades de mergulho turístico, inclusive para aulas iniciais de mergulho autônomo. A circulação da água na Baía de llha Grande, resultante dos efeitos de marés, ventos e diferenças de densidade, gera um movimento horário quase permanente em torno da ilha, com uma velocidade baixa de $10 \mathrm{~cm} / \mathrm{s}$ (Signorini, 1980). A água entra pela Baía de Ilha Grande pelo lado oeste, circula e se mistura com as águas menos salinas provenientes da Baía de Sepetiba a leste, sendo então 
desviada para o oceano. Entre a llha Grande e o continente, dados da Diretoria e Hidrografia de Navegação e Instituto Nacional de Pesquisas Hidroviárias, demonstraram uma alta freqüência de correntes e oscilações de pequenas amplitudes. Esse ambiente relativamente calmo aumentaria as chances de sobrevivência dos fragmentos pequenos encontrados na Ilha Imboassica, principalmente porque o fundo é constituído de lama (silte fino) (Mahiques \& Furtado, 1989), que pode ser facilmente ressuspendido, causando soterramento ou estresse nas colônias, já que a remoção de grãos de sedimento do tamanho de silte parece ser bastante dispendioso (Weber et al., 2006).

Além das tempestades, a característica do substrato, os organismos perfuradores e a morfologia dos corais são também muito importantes no processo de fragmentação (Highsmith, 1980, DeVantier \& Endean, 1989). Muitos trabalhos indicam a bioerosão como um dos fatores que mais contribuem para a fragmentação e desalojamento dos corais. Estes podem criar nichos morfologicamente diversos para o alojamento de muitos invertebrados, e é provável que locais com grande diversidade de corais forneça uma maior variedade de habitats e refúgios aos invertebrados comparado à locais com baixa diversidade (Idjadi \& Edmunds, 2006). Ben-Tzvi et al. (2005), estudando a associação poliqueta-coral, sugeriu que os corais teriam alguns benefícios com tal associação, como a melhoria da circulação da água próxima à superfície da colônia diminuindo a susceptibilidade ao branqueamento e o aumento da disponibilidade de nutrientes derivados dos materiais de excreção dos poliquetas.

Após a descalcificação das amostras, observamos a presença de muitos moluscos bivalves (principalmente do gênero Lithophaga) e poliquetas que deveriam estar dentro do exoesqueleto calcário. Estudos prévios com a espécie Mussismilia hispida coletadas no sudeste brasileiro revelaram um alto grau de infestação de bivalves, colônias de briozoários, esponjas e ascídias em suas bases bem como uma grande abundância de poliquetas vivendo dentro do esqueleto calcário (Nogueira, 2000; Nogueira, 2003). A infestação desses organismos deve fragilizar o exoesqueleto, tornando-o mais susceptível à fragmentação. Clark \& Morton (1999) estudando a bioerosão em Goniastrea, encontraram uma alta densidade de perfuradores, especialmente bivalves membros do gênero Lithophaga, e sugeriram que eles contribuiriam para o enfraquecimento dos corais vivos ou mortos. Quanto maior fosse o grau de perfuração, maior seria o enfraquecimento da colônia e a possibilidade de se desconectar do substrato. Outros trabalhos com Porites também encontraram altas taxas de perfuração que resultaram em fragmentação, geralmente completada por forças físicas, especialmente tempestades, resultando numa abundância de cobertura dessas espécies (Kojis \& Quinn, 1981b; Tomascik \& Sander, 
1987). No entanto, mesmo corais pouco perfurados são susceptíveis ao desalojamento durante tempestades e tufões, e às vezes cabeços inteiros são levados até as praias (Clark \& Morton, 1999).

Os fragmentos de $M$. decactis têm uma densidade do esqueleto relativamente pequena, seus coralitos diminutos têm septos e paredes bem finas de aparência frágil. A princípio, seria razoável supor que essa maior fragilidade do esqueleto facilitaria os processos de bioerosão. No entanto, a densidade do esqueleto parece não ser um fator determinante no controle da bioerosão, já que tanto correlações negativas quanto positivas foram encontradas entre $\mathrm{o}$ aumento da densidade do esqueleto e a bioerosão (Sammarco \& Risk, 1990; Highsmith, 1981; Highsmith, 1983), ou nenhuma relação foi encontrada entre a densidade esqueletal e o número de perfuradores (Clarck \& Morton, 1999).

A reprodução através da fragmentação ocorre em várias intensidades, desde um evento raro ou ocasional até uma característica central na história de vida de uma determinada espécie (Highsmith, 1982). Assim, as colônias de M. decactis da llha Imboassica parecem utilizar a fragmentação como um evento ocasional, propiciado pela bioerosão de suas colônias, talvez pela fragilidade de seu exoesqueleto, e pelos eventos de tempestades, principalmente durante $\mathrm{o}$ inverno, formando fragmentos pequenos que sobrevivem graças a um ambiente relativamente estável e calmo durante o resto do ano.

\subsection{Plasticidade Fenotípica}

Além da forma de crescimento nodular encontrada em áreas exposta à alta intensidade luminosidade, encontramos também colônias de $M$. decactis com forma de crescimento incrustante que muitas vezes apresentava um aspecto mais liso e achatado e se localizava em paredões verticais mais sombreados. A morfologia da colônia parece depender da luz como um fator de estruturação (Vermeij \& Bak, 2002). Uma vez que a comunidade onde se encontram os corais pode ser caracterizada por uma complexidade estrutural, a quantidade de luz recebida por organismos que ocupam a mesma profundidade pode ser diferente dependendo da posição que ocupam dentro dessa comunidade, resultando numa luminosidade diferente equivalente a uma mudança substancial de profundidade (Vermeij \& Bak, 2002). A morfologia nodular e incrustante dentro da mesma espécie, provavelmente, deve refletir uma plasticidade fenotípica da mesma. A plasticidade fenotípica é a capacidade de mudança morfológica e/ou fisiológica que um organismo apresenta em resposta às diferentes condições ambientais (Bradshaw, 1965), como por exemplo, a disponibilidade de luz. Assim como as plantas, os corais são animais sésseis que não 
possuem a capacidade de se locomover para outro lugar quando as condições ambientais não são favoráveis. Por isso, para esses organismos a plasticidade fenotípica pode ter um considerável significado adaptativo (Bradshaw, 1965). O formato incrustante e mais achatado de $M$. decactis encontrada em lugares mais sombreados deve ser favorecido quando a disponibilidade de luz é limitada, enquanto que em locais mais expostos a morfologia nodular e menos achatada deve otimizar a captação de luz.

Muko et al. (2000) observaram que Porites sillimaniane de Okinawa, Japão, variava sua morfologia dramaticamente de acordo com a intensidade luminosa, indo desde $\circ$ formato tabular até 0 formato arborescente. Fragmentos tabulares transplantados para condições de alta luminosidade iniciaram o desenvolvimento de ramos em 8 meses, enquanto que aqueles submetidos à baixa luminosidade permaneceram achatados. O estudo sobre a plasticidade fenotípica de Madracis mirabilis constatou inúmeras modificações morfológicas nos fragmentos em resposta ao transplante para um novo ambiente, tornando-se similares aos residentes coespecíficos em cada tratamento ambiental (Bruno \& Edmunds, 1997). Outro trabalho com a mesma espécie demonstrou que, através da plasticidade fenotípica, o ajuste no espaçamento entre os ramos da colônia frente às condições de fluxo (forte ou fraco), possibilitava uma maior tolerância quando sob condições desfavoráveis. A diminuição do espaçamento entre os ramos quando submetidos à um fluxo fraco, e o aumento do espaçamento sob um fluxo forte trariam benefícios importantes para as taxas metabólicas dessas colônias (Bruno \& Edmunds, 1998).

A posição e a localização das colônias incrustantes de $M$. decactis permitem deduzir que elas devem ser derivadas do recrutamento de plânulas, uma vez que estão fixadas em paredes verticais (apesar da plânula incubada não indicar necessariamente uma reprodução sexuada vide Sttodart, 1983). As formas mais nodulares, como discutido anteriormente, podem sofrer o processo de fragmentação e gerar recrutas assexuados. A alta mortalidade de recrutas sexuados juvenis, devido à combinação de fatores como o tamanho diminuto e a predação, parece ser um fenômeno comum entre os corais (Kojis \& Quinn, 1981b; Wallace, 1985; Szmant, 1991; Maida \& Ferreira, 1995), sendo que grande parte da pressão seletiva deve ocorrer nessa fase do ciclo de vida (Szmant, 1986). Esse panorama pode conferir à plasticidade fenotípica um importante valor, na medida em que possibilita aos recrutas sexuadamente derivados ocuparem novos habitats, como por exemplo, paredes verticais mais sombreadas, ambientes talvez menos concorridos do que os habitats mais iluminados. Tal plasticidade pode ser um importante componente da estratégia 
da história de vida de populações clonadas, suavizando os efeitos da pouca variabilidade genética (Bradshaw, 1965; Bruno \& Edmunds, 1997).

\subsection{Arranjo das gônadas}

Madracis decactis é hermafrodita com ovócitos e espermatócitos se desenvolvendo em mesentérios diferentes dentro do mesmo pólipo. Todas as colônias apresentaram dez lóculos gástricos cada qual com um par de mesentérios, um feminino e outro masculino, e em raras exceções observamos dois mesentérios do mesmo sexo ocorrendo no mesmo lóculo. Esse padrão sexual (hermafroditismo) e o arranjo das gônadas (localizadas em mesentérios separados) estão de acordo com outras espécies da família Pocilloporidae, a qual $M$. decactis pertence, e parecem ser bastante conservativos ao nível de família (Harrison, 1985; Shlesinger et al., 1998). Entretanto, Vermeij et al. (2004) constataram um padrão diferenciado em seis espécies de Madracis no Caribe, incluindo M. decactis:. Além de apresentarem apenas 10 mesentérios por pólipo (e não 10 pares, como no presente trabalho), cerca de $60 \%$ deles continha gônadas femininas e masculinas se desenvolvendo juntas, sendo que M. decactis apresentou o menor grau de hermafroditismo, com $50 \%$ dos mesentérios contendo gametas de apenas um sexo. No presente estudo, porém, em nenhum dos cortes analisados foram observados gônadas masculinas e femininas se desenvolvendo no mesmo mesentério, assim como no estudo com a mesma espécie no Complexo Recifal de Abrolhos (Castro \& Pires, 2006). Comparações morfológicas e genéticas seriam necessárias para se averiguar se se tratam da mesma espécie (Castro \& Pires, 2006), ou então, se existe uma variação intraespecífica no número de mesentérios e no padrão de distribuição das gônadas entre as duas localidades (Brasil e Caribe), como ocorre com outras características (modo liberador x modo incubador), que variam dentro da mesma espécie localizadas em regiões geograficamente distintas (Harrison, 1985; Harrison \& Wallace, 1990).

Rinkevich \& Loya (1979) observaram que as gônadas de Stylophora pistillata encontravam-se ligadas ao mesentério através de hastes ou pedúnculos que se projetavam para dentro da cavidade gastrovascular, e sugeriram que esse padrão seria comum nos corais incubadores e de pólipos pequenos, geralmente formas ramificadas. Alguns autores, estudando Pocillopora damicornis, também observaram esse mesmo arranjo e sugeriram que ele deveria ser típico dos pociloporídeos e não de corais incubadores (Harriott, 1983b; Stoddart \& Black, 1985). No entanto, esse padrão não parece estar presente em todos os pociloporídeos (Glynn et al., 1991; Sier \& Olive, 1994; Kruger \& Schleyer, 1998). Apesar de Vermeij et al. (2004) ter encontrado esse tipo de arranjo nas espécies de Madracis do Caribe, o presente 
estudo não observou tal característica. A maioria das gônadas se desenvolveu dentro do mesentério entre os músculos retratores longitudinais e o filamento do mesentério, assim como M. decactis da região do Complexo Recifal de Abrolhos (Castro \& Pires, 2006). Em alguns casos, porém, as gônadas masculinas e/ou femininas pareceram se desenvolver mais lateralmente ao mesentério, dando a impressão de estarem conectadas e não dentro dele, como observou Sier \& Olive (1994) em Pocillopora verrrucosa. Talvez esse arranjo tenha sido interpretado como "gônadas com pedúnculos conectados ao mesentério" em outros estudos.

\subsection{Estabelecimento dos estágios da gametogênese}

A detecção e a distinção dos primeiros estágios da gametogênese ao nível da microscopia óptica se mostraram tarefas difíceis já nos primeiros trabalhos que enfocaram a gametogênese em corais (Szmant-Froelich et al., 1980; Stoddart \& Black, 1985). No presente trabalho, o ciclo da ovogênese foi menos óbvio do que da espermatogênese, em razão de uma maior arbitrariedade na determinação dos estágios da ovogênese (principalmente nos estágios iniciais) e por causa da presença mais constante dos três estágios ao longo das coletas em função de uma produção mais contínua de ovócitos.

Os primeiros estágios da ovogênese foram mais arbitrários que os da espermatogênese e foram baseados principalmente na localização da célula dentro do mesentério e no seu tamanho (Campbell, 1874). As espermatogônias foram de mais fácil visualização, pois sempre se encontravam em ninhos formados por dezenas de células. Já as ovogônias apresentavam-se geralmente sozinhas e ainda eram muito parecidas com células intersticiais, dificultando sua distinção.

Assim, o estabelecimento dos estágios da gametogênese parece depender muito da experiência e da interpretação do observador e pode mudar de caso para caso dependo dos critérios utilizados (Acosta \& Zea, 1997). Essas diferenças no estabelecimento dos estágios, principalmente na detecção dos estágios iniciais, podem resultar em ciclos reprodutivos com durações diferentes.

Além da detecção dos estágios iniciais, o estabelecimento do estágio maduro do ovócito também foi difícil. Muitos trabalhos descreveram os ovócitos maduros como um estágio bem diferenciado, podendo apresentar uma coloração do citoplasma distinta dos demais, geralmente em tons intensos de vermelho ou rosa (Glynn et al., 1994; Lins de Barros et al., 2003, Neves \& Pires, 2002), uma camada cortical aparente (Szmant-Froelich et al., 1980; Harrison \& Wallace, 1990), grandes quantidades de vesículas de lipídeo no citoplasma (Kruger \& Schleyer, 1998; Pires et al., 1999), mas, principalmente, foram caracterizados pela posição periférica do núcleo (Szmant- 
Froelich et al., 1985, Goffredo et al., 2002; Hetzel \& Babcock, 2002). A migração do núcleo para a periferia com o possível formato de "U" (Szmant-Froelich et al., 1980, Hetzel \& Babcock, 2002; Lins de Barros et al., 2003; Goffredo et al., 2005), deve facilitar o processo de fertilização do ovócito (Szmant-Froelich et al., 1980). Os maiores ovócitos encontrados na última coleta (30/04/05), antes do desaparecimento dos gametas, e na coleta de 20/05/06, quando só uma colônia continha gametas, não apresentaram características marcantes que possibilitaram uma distinção imediata do estágio IV (maduro). Alguns apresentaram um núcleo um pouco mais deslocado para a periferia e placas de vitelo que davam um aspecto rachado ao citoplasma, mas outros, com tamanhos semelhantes, apresentavam um núcleo ainda bem centralizado, dificultando assim, a distinção do estágio III e do IV. As características diferenciadas que parecem ser bastante comuns nos ovócitos maduros (camada cortical, grande quantidade de vesículas de lipídeos ou núcleo periférico em formato de "U”) não foram observadas.

$\mathrm{Na}$ coleta de 30/04/05 observamos espaços vazios deixados pela liberação dos cistos, dando indício de que, possivelmente, já havia ovócitos maduros (ou quase) nas colônias, já que o diâmetro máximo encontrado $(108,8 \mu \mathrm{m})$ foi semelhante ao diâmetro máximo de $113 \mu \mathrm{m}$ do ovócito maduro encontrado em $M$. decactis de Abrolhos (Castro \& Pires, 2006). Assim, talvez as características desse ovócito maduro do presente trabalho não sejam tão conspícuas como as dos demais trabalhos, ou talvez eles ainda não se encontravam totalmente maduros.

No entanto, alguns trabalhos sugerem que a permanência dos ovócitos maduros dentro dos pólipos seja muito breve o que dificultaria sua observação (Stoddart \& Black, 1985, Szmant-Froelich, 1985). Ovócitos maduros de Montastrea cavernosa de Porto Rico parecem estar presentes apenas por alguns dias antes de serem liberados, e por isso foram vistos somente em algumas amostras, apesar do intenso esforço de coleta (de duas em duas semanas durante um ano) (Szmant, 1991).

Assim como os ovócitos maduros, os espermatozóides também parecem permanecer pouco tempo dentro dos pólipos (Ward, 1992), e as chances de encontrarmos esse estágio torna-se menor se os intervalos entre as coletas forem grandes (Stoddart \& Black, 1985; Pires \& Caparelli, 2002). Até uma semana antes da liberação dos gametas, por exemplo, nenhum cisto espermático maduro de Montastrea annularis foi observado, além disso, o número de colônias contendo cistos maduros foi de apenas 32\% (Van Veghel, 1994). No presente trabalho, apesar do intervalo entre as coletas ter sido relativamente grande (de dois em dois meses), foram encontradas dez colônias com poucos pólipos ( $n=31 / 192)$ contendo cistos 
espermáticos maduros na última coleta antes do desaparecimento dos gametas $(30 / 04 / 05)$.

\subsection{Absorção dos ovócitos}

Nos últimos meses do ciclo reprodutivo observamos alguns ovócitos que aparentavam estarem se degenerando e sendo reabsorvidos pelo próprio pólipo ou por outros ovócitos. Esse fenômeno de reabsorção foi descrito em corais pela primeira vez por Rinkevich \& Loya (1979), que sugeriram que os ovócitos que permaneciam no pólipo deveriam englobar outros ovócitos para a obtenção de nutrientes. SzmantFroelich et al., (1980) também destacaram que o aumento de tamanho dos ovócitos nos últimos estágios era dramático e que o material utilizado para esse crescimento poderia vir da absorção de ovócitos menores enquanto os maiores cresciam. Apesar desse processo parecer bastante comum entre os corais escleractínios (Wyers, 1985; Sier \& Olive, 1994; Kruger \& Schleyer 1998; Lam, 2000; Pires et al., 2002, Neves \& Pires, 2002), algumas espécies de Acropora não apresentaram degeneração de ovócitos em desenvolvimento, sendo o número de ovócitos por pólipo constante do início até o final da ovogênese (Wallace, 1985), enquanto que Tomascik \& Sander (1987), estudando Porites porites, consideraram o processo de absorção uma fonte de alimentação pouco importante para o desenvolvimento dos ovócitos.

\subsection{Plânulas}

A ausência de embriões e plânulas em estudos envolvendo análises histológicas e o desaparecimento repentino dos gametas nos pólipos levaram alguns autores a inferirem o modo liberador de gametas nas espécies estudadas (Kojis \& Quinn, 1981a; Soong, 1991, Sier \& Oliver, 1994). Além da ausência de embriões e plânulas, outros autores se basearam na sincronia do amadurecimento dos gametas, e possível liberação sincrônica desses gametas, como evidências do modo liberador (Glynn et al., 1991, Pires et al., 1999). Entretanto, a não observação de plânulas e embriões nos cortes nem sempre são evidências do modo liberador, uma vez que a plânula pode ser incubada por apenas um curto período de tempo, dificultando assim a sua observação (Stimson, 1978; Harriot, 1983; Stoddart \& Black, 1985; Soong, 1991; Castro \& Pires, 2005). Vermeij et al. (2003) capturaram plânulas de Madracis através de redes posicionadas ao redor dessas colônias na região do Caribe. Entretanto, em trabalho posterior com as mesmas espécies na mesma região, nenhum embrião ou plânula foi encontrado nos mais de 8000 cortes histológicos analisados, por isso os autores sugeriram uma mudança da denominação "brooder" (incubador) para "quick releaser" (liberador rápido) para as espécies de Madracis (Vermeij et al., 2004). Sttodart \& Black 
(1985) encontraram plânulas nas colônias de Pocillopora damicornis, mas não observaram os estágios de desenvolvimento conectando ovócitos maduros e plânulas (os embriões), e atribuíram isso ao rápido desenvolvimento do ovócito fertilizado ou à dificuldade de reconhecimento dos estágios iniciais da embriogênese.

Alguns autores, porém, acreditam que plânulas originadas da fertilização interna se desenvolvam muito mais lentamente do que plânulas oriundas da fertilização externa (Harrison \& Wallace, 1990). O rápido processo da embriogênese dos embriões originados da fertilização externa minimizaria o tempo de permanência no plâncton e diminuiria a mortalidade das plânulas, em contrapartida, os embriões internamente fertilizados poderiam ter um desenvolvimento mais longo porque estariam protegidos pelo pólipo parental, e talvez até alimentados por ele (Hetzel \& Babcock, 2002).

De fato, as espécies incubadoras Porites astreoides e Siderastrea radians do Caribe incubam de 9 até 12 meses (Szmant, 1986), Balanophyllia europea do Mediterrâneo incuba por 4 até 5 meses, enquanto que $B$. elegans de 14 até 15 meses (Fadlallah \& Pearse, 1982). No entanto, Tanner (1996) estudando três espécies incubadoras, encontrou diferenças no período de incubação entre elas, sendo que a baixa porcentagem de colônias de Pocillopora damicornis com plânulas seria uma conseqüência do rápido crescimento e liberação destas, enquanto que Stilophora pistillata e S. hystrix, teriam longos períodos de permanência da plânula dentro dos pólipos e por isso apresentariam pouca sincronia na liberação, aumentando assim o número de observações de colônias com plânulas.

No presente trabalho, apesar do grande número de pólipos analisados (mais de 1800), não observamos nenhum embrião e nenhuma plânula nos cortes histológicos, provavelmente, por causa da curta permanência desses estágios dentro do pólipo ("quick releaser"), como sugerido por Vermeij et al. (2004). Os cortes histológicos dos pólipos no pico da atividade reprodutiva, mostraram que os lóculos gástricos (cavidade gastrovascular) ficam quase que totalmente preenchidos pelo grande número de ovócitos e cistos em desenvolvimento, como observado em outras espécies com pólipos pequenos como Stylophora pistallata (Rinkevich \& Loya, 1979) e Pocillopora verrucosa (Fadlallah, 1985). Nesse estágio, é provável que aconteça pouca ou nenhuma atividade de alimentação heterotrófica (Harrison \& Wallace, 1990). Dessa maneira, devido ao pequeno tamanho do pólipo, talvez os embriões sejam forçados a saírem rapidamente da cavidade gastrovascular, disponibilizando espaço para o desenvolvimento de novos embriões e para a circulação de água, sem comprometer as atividades de alimentação, trocas gasosas e de metabólicos que também se realizam nessa cavidade. 
Harrison \& Wallace (1990) propuseram que o período de liberação de plânulas tenderia a ser mais curto em latitudes mais altas, e ocorreriam em períodos mais longos ou durante todo o ano em regiões tropicais próximas ao equador. Madracis decactis do Caribe $\left(12^{\circ} \mathrm{N}\right)$ apresenta um período de liberação de plânulas longo que vai de março até dezembro (Vermeij et al., 2003), enquanto que M. decactis de llha Grande $\left(23^{\circ} \mathrm{S}\right)$ tem um período de liberação mais curto de cerca de um mês (entre abril e maio). Assim, esse curto período de liberação, somado à curta permanência das plânulas dentro do pólipo, e aos intervalos de dois meses entre as coletas podem ter dificultado a observação de plânulas nos cortes analisados.

Entretanto, não podemos descartar a possibilidade de $M$. decactis da llha Grande, bem como a do Complexo Recifal de Abrolhos (Castro \& Pires, 2006), serem liberadoras de gametas, já que essa característica reprodutiva pode variar dentro da mesma espécie (Harrison \& Wallace, 1990). Um dos gêneros de corais mais comum e bem estudado no Indo-Pacífico, Pocillopora, apresenta grande variação do modo reprodutivo de suas espécies: $P$. verrucosa é incubadora no Atol Enewetak no Oceano Pacífico (Stimson, 1978), e liberadora de gametas no Mar Vermelho (Fadlallah 1985; Shlesinger \& Loya, 1985); P. damicoris libera gametas no Pacífico Leste (apesar da liberação nunca ter sido observada) (Glynn et al., 1991), mas incuba plânulas na maioria dos demais lugares (Harriott, 1983b; Sttodart, 1983; Tanner, 1996, Tioho et al., 2001), ou ainda pode apresentar os dois modos de reprodução (Ward, 1992). Harrison \& Wallace (1990) relataram alguns casos onde descrições da mesma espécie apresentando o modo incubador em uma determinada região, e o liberador em outra estavam, provavelmente, equivocadas e eram frutos de problemas taxonômicos (espécies identificadas erroneamente) ou de má interpretação (identificação equivocada de plânulas nos cortes histológicos), e sugeriram que, nesses casos, estudos taxonômicos e genéticos seriam necessários para determinar se o modo de reprodução seria espécie-específico ou variável em certas espécies de corais. Portanto, para a exata determinação do modo reprodutivo de $M$. decactis em llha Grande, seria necessário fazer a observação de plânulas ou embriões nos cortes histológicos, ou a observação direta da planulação nessas colônias.

\subsection{Ciclo reprodutivo}

\subsubsection{Fatores que influenciam no início e época do ciclo reprodutivo:}

O ciclo reprodutivo de uma espécie pode ser influenciado tanto por fatores endógenos (relógio biológico) como por fatores exógenos (condições ambientais) (Olive \& Garwood, 1983). Segundo Maclean \& Hall (1987) algum tipo de programa 
genético deve estar envolvido no mecanismo que induz a diferenciação das células germinativas. Um ritmo biológico, ou seja, um relógio endógeno circanual foi sugerido para Montastrea annularis (Van Veghel, 1994) e Stylophora pistillata (Rinkevich \& Loya, 1979). O período reprodutivo de S. pistillata em 1976, por exemplo, iniciou-se em dezembro de 1975 e terminou em junho (8 meses), enquanto que em 1977, iniciou em fevereiro e terminou em julho (6 meses). Harriott (1983b) encontrou diferenças na freqüência de gônadas de um ano para o outro nas colônias de Pocillopora damicornis no Recife da Grande Barreira, Austrália, indicando uma variação na atividade gametogênica, atribuída às variações nas condições climáticas e oceânicas (Ward, 1992).

M. decactis apresentou uma variação na distribuição das freqüências dos estágios no início do ciclo reprodutivo. Em outubro e dezembro de 2004 observamos uma grande freqüência de ovócitos III, enquanto que em 2005 praticamente nenhum ovócitos III foi encontrado de outubro até dezembro, sendo predominante a freqüência de ovócitos I. Essa variação pode ser devido à uma variação endógena no ciclo reprodutivo da espécie, ou então uma conseqüência da diferença de temperatura média superficial da água do mar nos meses iniciais do ciclo reprodutivo (set/out/nov), de 1 até $2^{\circ} \mathrm{C}$ entre os dois anos. Talvez a maior temperatura superficial do mar (tsm) em 2005 tenha estimulado uma maior e mais longa produção de células germinativas, apesar disso não ter refletido no número de ovócitos III produzidos no pico reprodutivo entre os dois anos.

Em fevereiro, observamos o pico da irradiação solar, havendo uma queda progressiva desses valores nos meses seguintes. A irradiação solar e a tsm são claramente interdependentes, pois em última análise, é a irradiação solar que guia a tsm. Os efeitos da irradiação máxima são observados um ou dois meses depois, quando a tsm atinge seu pico (Van Woesik et al., 2006). É nesse período também, que a atividade reprodutiva de Madracis decactis foi mais intensa, pois encontramos a maior quantidade de pólipos férteis, de ovócitos (de todos os estágios) e o maior aumento do diâmetro do ovócito III.

Van Woesik (2006) sugeriu que a irradiação solar, ou pelo menos, a fração fotossinteticamente ativa do espectro utilizada pelo simbionte influenciava no ciclo reprodutivo dos corais. Alguns estudos mostraram que a nutrição autotrófica seria mais que suficiente para manter as necessidades basais de alguns corais (Muscatine et al., 1984; Edmunds \& Davies, 1986). Rinkevich (1989) forneceu a primeira evidência direta de que uma proporção significativa de carbono fixado pelas zooxantelas era incorporada nas plânulas, isto é, pelo menos uma parte das necessidades energéticas de um coral hermatípico utilizada para a produção de plânulas era sustentada pela 
translocação de produtos originados da fotossíntese do simbionte, a "sobra energética", portanto, deveria ser canalizada para outras atividades, entre elas a produção de gametas e seus estoques energéticos na forma de lipídeos. A alocação de recursos, no entanto, parece acontecer de forma hierárquica: primeiro, viria a manutenção, o reparo, o crescimento, e por fim a reprodução (Harrison \& Wallace, 1990). Jokiel \& Guinther (1978) constataram que a habilidade de Pocillopora damicornis para se reproduzir era bastante comprometida sob condições subótimas, muito mais do que a taxa de crescimento. Algumas espécies localizadas em ambientes de baixas temperaturas apresentaram taxas de crescimento maiores, priorizando o aumento de tamanho, podendo depender apenas da fragmentação como única forma de reprodução (Richmond, 1987; Fan \& Dai, 1995). Portanto, talvez seja mais vantajoso que os estágios reprodutivos energeticamente mais custosos aconteçam quando a produção de energia seja mais alta (provavelmente nos meses de primavera/verão), possibilitando até a manutenção do crescimento da colônia, ao passo que se a reprodução ocorrer quando a energia estiver pouco disponível, o crescimento poderá diminuir ou mesmo ser interrompido (Tanner, 1996).

Os primeiros ovócitos foram observados no começo de outubro, marcando o início do ciclo reprodutivo de $M$. decactis, que coincidiu também com o início da elevação da tsm na região. A variação média anual da tsm na região é relativamente alta (mais que $8^{\circ} \mathrm{C}$ ) o que resulta em temperaturas bem diferenciadas no inverno e no verão, fornecendo assim um bom sinal ou estímulo para o início das atividades reprodutivas. Essa mudança da temperatura da água, de um padrão de diminuição para um de aumento, é geralmente citada como um dos principais mecanismos de controle para o início do desenvolvimento da gametogênese (Fadlallah, 1985; Kruger \& Schleyer, 1998; Mc Guire, 1998; Vermeij et al., 2003). No entanto, Kojis \& Quinn (1986) questionaram o papel da tsm na inicialização da gametogênese em corais de ambientes rasos, já que em habitats como esses a variação diária da temperatura era grande, e sinais fornecidos pela tsm para o início da gametogênese poderiam ser confusos. Os autores sugeriram que o fotoperíodo teria um padrão muito mais constante e seria assim, uma melhor pista para a inicialização da gametogênese. Outros autores também sugeriram que o fotoperíodo seria mais importante que a tsm na regulação do início do ciclo reprodutivo em ambientes com pouca variação de temperatura (Acosta \& Zea, 1997; Fan \& Dai, 1998).

Como a tsm varia significativamente conforme a latitude, devido, principalmente, à diferença no ângulo de incidência dos raios solares do equador em direção aos pólos, vários estudos sobre as relações entre a latitude (na verdade, sua influência na tsm) e os ciclos reprodutivos das espécies de corais foram desenvolvidos 
na tentativa de compreender porque a época dos eventos reprodutivos (gametogênese e liberação de plânulas/gametas) variava geograficamente (com eventos descritos em todo os meses do ano em diferentes localidades ao redor do mundo) (Mendes \& Woodley, 2002).

Harrison \& Wallace (1990) publicaram uma revisão, onde tentaram estabelecer um padrão entre a latitude e os ciclos reprodutivos com o levantamento de diversos trabalhos realizados até então (principalmente com espécies incubadoras de plânulas). Eles sugeriram que tanto o ciclo reprodutivo quanto o tempo de liberação das plânulas deveriam ser mais curtos em latitudes altas e mais longos em latitudes baixas. As espécies em latitudes altas, submetidas à temperaturas mais baixas em alguns meses do ano, estariam limitadas e se reproduzirem somente quando a temperatura subisse e se tornasse ótima para a reprodução, restringindo assim a duração do ciclo reprodutivo, ao passo que próximo ao equador, as temperaturas seriam mais altas e estáveis, tornando-se um fator pouco limitante para a atividade reprodutiva das espécies. Essa idéia já tinha sido levantada anos antes por Pearse (1974) quando este estudou o período reprodutivo de ouriços-do-mar, e hipotetizou que em latitudes mais altas as espécies se reproduziriam durante a época mais quente do ano, em latitudes intermediárias a época reprodutiva seria mais longa, e no equador ela ocorreria durante o ano todo.

Entretanto, comparando os trabalhos sobre a reprodução de Madracis decactis em outras latitudes e o presente trabalho não encontramos essa relação. $M$. decactis de Curaçao $\left(12^{\circ} \mathrm{N}\right)$ apresentou um ciclo reprodutivo de seis meses (Vermeij et al., 2004), apesar de, em um trabalho anterior com a mesma espécie na mesma região, os autores terem encontrado um período de planulação extenso de março até dezembro (dez meses). A duração do ciclo reprodutivo de $M$. decactis na llha Imboassica $\left(23^{\circ} \mathrm{S}\right)$ é de cerca de sete meses (outubro-abril/maio), dois meses a mais que em Abrolhos (16-18 $\mathrm{S}$ ) que se inicia em dezembro e vai até março/abril (Castro \& Pires, 2006). A diferença na definição dos estágios da gametogênese e os intervalos de coletas podem ter causado tal diferença (Acosta \& Zea, 1997). É importante ressaltar também que as colônias coletadas no presente trabalho são, na sua maioria, fragmentos e isso talvez tenha influenciado no desenvolvimento do ciclo reprodutivo. Alguns trabalhos demonstraram que injúrias mecânicas e fragmentação podem atrasar significativamente o início do ciclo reprodutivo, afetar a fecundidade dos corais ou até causar a perda da habilidade reprodutiva (Szmant, 1986; Smant-Froelich, 1991; Zakai et al., 2000).

Em contraposição à idéia de que em latitudes mais altas a duração do ciclo reprodutivo seria menor (devido a uma faixa menor de tsm ótima para a reprodução), 
alguns autores sugeriram justamente o contrário, ou seja, eles propuseram que em ambientes com temperaturas mais baixas o ciclo reprodutivo dos corais seria mais extenso. Condições de tsm mais baixas prolongariam a gametogênese, uma vez que a taxa de maturação dos gametas seria mais lenta (Stoddart \& Black, 1985; Harii et al., 2001). M. decactis da área de estudo, por exemplo, experimenta na época reprodutiva, temperaturas médias mensais que variam de 20 até $27^{\circ} \mathrm{C}$, enquanto que em Abrolhos as temperaturas, também na época reprodutiva, variam de 25 até $28^{\circ} \mathrm{C}$ (dado obtido do NOMADS LAS Server - NOAA). Essa diferença nas temperaturas poderia resultar numa gametogênese mais extensa na região de Ilha Grande. Além disso, um maior investimento energético na produção dos ovócitos também poderia estender a duração do ciclo reprodutivo, na medida em que plânulas maiores (com mais estoque energético) poderiam ter melhores chances de sobrevivência em condições mais extremas. Assim, as colônias investiriam mais na quantidade, e talvez qualidade de reserva energética do ovócito em resposta às condições ambientais mais desfavoráveis em altas latitudes (Sier \& Oliver, 1994; Fan \& Dai, 1995; Acosta \& Zea, 1997). Entretanto, o diâmetro máximo dos maiores ovócitos observados na llha Grande $(108,8 \mu \mathrm{m})$ e em Abrolhos $(113 \mu \mathrm{m})$ foram praticamente iguais, indicando que o investimento, pelo menos quantitativo de energia parece ser igual. No entanto, como discutido anteriormente, se esses maiores ovócitos observados no presente trabalho não corresponderem aos ovócitos maduros, e estes por sua vez, tiverem um tamanho maior, pode ser que exista uma diferença no investimento da produção de ovócitos entre as colônias de Ilha Grande e Abrolhos.

\subsubsection{Liberação}

Harrison \& Wallace (1990) propuseram também que as espécies em latitudes mais altas tenderiam a liberar seus gametas mais tarde do que as espécies em latitudes mais baixas. Isso ocorreria porque devido à diferença latitudinal, a elevação da temperatura ocorreria mais cedo em latitudes mais baixas, e conseqüentemente, a gametogênese iniciaria mais cedo o mesmo acontecendo com a liberação. Pocillopora verrucosa nas Maldivas $\left(4^{\circ} \mathrm{N}\right)$, por exemplo, libera em março/abril; no Mar Vermelho na latitude de $24^{\circ} \mathrm{N}$ no final de maio, e no extremo norte $\left(29^{\circ} \mathrm{N}\right)$ em julho/agosto (Fadlallah, 1985; Sier \& Olive, 1994). Esse atraso da liberação em latitudes mais altas ocorre também em Isolitary Islands $\left(30^{\circ} \mathrm{S}\right)$, onde a liberação acontece de 2 até 5 meses depois de no Recife da Grande Barreira (10-24 $\mathrm{S}$ ), Austrália (Wilson \& Harrison, 2003), assim como nos recifes da Ilha Shikoku $\left(32^{\circ} \mathrm{N}\right)$ com relação às Ilhas Ryukyu $\left(24-29^{\circ} \mathrm{N}\right)$, Japão (Hayashibara et al., 1993; Van Woesik, 1995). Até a diferença longitudinal entre Curaçao $\left(12^{\circ} \mathrm{N}\right)$ e Bonaire $\left(12^{\circ} \mathrm{N}\right)$ foi considerada como 
causa da diferença no período reprodutivo devido à diferença na época da elevação da tsm (Van Veghel, 1994).

Apesar do atraso de um mês na liberação das plânulas do presente trabalho (abril/maio) em relação à liberação no Complexo Recifal de Abrolhos (março/abril) (Castro \& Pires, 2006), estar aparentemente relacionada com a diferença de um mês no início do aumento da tsm entre as duas regiões, parece equivocado estabelecermos uma relação tão simples entre esses fatores. Apesar de, em Abrolhos a tsm aumentar entre agosto/setembro (dado obtido do NOMADS LAS Server NOAA), o início da atividade reprodutiva de $M$. decactis é observado apenas em dezembro, enquanto que na região de llha Grande a atividade reprodutiva inicia-se em outubro e, portanto, o aumento precoce da tsm em Abrolhos não resultou num início precoce da atividade reprodutiva. Nesse caso, parece que o atraso da época na liberação não está diretamente relacionado com o atraso do aumento da tsm, mas sim com um ciclo reprodutivo mais longo de $M$. decactis em latitudes mais altas postergando a liberação.

Essa relação entre latitude $\mathrm{x}$ época da liberação parece não se adequar também em muitas localidades estudadas, uma vez que a liberação de gametas acontece precocemente em muitas latitudes altas. No Brasil, por exemplo, tanto Siderastrea stellata como Mussismilia hispida de Abrolhos (18 $\left.{ }^{\circ} \mathrm{S}\right)$ liberam seus gametas/plânulas meses depois do que em Búzios (22ㅇ) onde a liberação acontece na tsm máxima, antes do período de diminuição da temperatura causado pela ressurgência (Neves \& Pires, 2002; Lins de Barros, 2003, Lins de Barros \& Pires, 2007). Van Veghel (1994) observou que tanto o início da gametogênese quanto a liberação dos gametas de Mostrastrea annularis ocorriam cerca de um mês depois em localidades mais quentes como Curaçao e Bonaire do que em regiões mais frias do Caribe. Outras espécies de latitudes mais altas, do sul de Taiwan, também apresentaram um período reprodutivo mais precoce (Fan \& Dai, 1998).

Outros estudos, por sua vez, não encontraram nenhuma variação na liberação de gametas em espécies localizadas em áreas geograficamente distintas. Talvez um dos eventos mais conhecidos no estudo da reprodução dos corais seja a descoberta da liberação de gametas em massa ("mass spawning") que ocorre simultaneamente com mais de cem espécies na costa leste da Austrália (Babcock et al., 1986). A liberação em massa envolve populações inteiras localizadas em recifes amplamente separados (por mais de $500 \mathrm{~km}$, ou cerca de $5^{\circ}$ de latitude) que liberam seus gametas em três ou quatro noites durante a primavera e/ou verão. Mais tarde Babcock et al. (1994) confirmaram a mesma sincronicidade na costa oeste da Austrália, com a liberação em massa de mais de 184 espécies nas proximidades de Houtman Abrolhos 
Islands $\left(28-29^{\circ} \mathrm{S}\right)$ no mesmo mês que em localidades mais ao norte (Ningaloo, $22^{\circ} \mathrm{S}$ ), apesar da diferença do período em que ocorriam as temperaturas mínimas entre as duas localidades. Os autores sugeriram que a temperatura não era um fator essencial na determinação da época da liberação, e que esse papel era realizado pelo fotoperíodo que forneceria um sinal mais constante para as colônias. Curiosamente, em Bermudas $\left(32^{\circ} \mathrm{N}\right)$, Porto Rico $\left(18^{\circ} \mathrm{N}\right)$ e Panamá $\left(8-10^{\circ} \mathrm{N}\right)$ os períodos de liberação de Mostastrea annularis parecem uniformes, apesar da temperatura anual e os ciclos de fotoperíodo serem bem diferentes ao longo dessa faixa latitudinal (Szmant, 1991). Soong (1991) também não encontrou nenhuma variação geográfica na época da liberação da plânula nas quatro espécies que foram estudadas em mais de uma localidade.

Por outro lado, o contrário também já foi registrado, ou seja, populações da mesma espécie localizadas num mesmo local, liberando gametas em períodos diferentes. Wilson \& Harrison (1997) constataram que a época de liberação entre as diferentes espécies das Solitary Islands, Austrália, não era sincrônica, e o grau de sincronia da liberação dentro de cada espécie também era variável (algumas populações liberavam num curto período de tempo, outras liberavam por extensos períodos sem sincronização). O mesmo acontece no Mar Vermelho, onde o período de liberação das plânulas/gametas de doze espécies ocorreu em diferentes estações, diferentes meses e em diferentes fases da lua (Shlesinger \& Loya, 1985). As próprias espécies brasileiras presentes no Complexo Recifal de Abrolhos apresentam durações da gametogênese e períodos de liberação distintos (Tabela 1).

Portanto, os vários estudos a cerca dos ciclos reprodutivos dos corais (duração e período de liberação) e suas relações com a tsm, e por conseqüência, com a latitude em que se encontram, parecem indicar que outros fatores, além da temperatura, devem influenciar na atividade reprodutiva desses animais (Mendes \& Woodley, 2002; Penland et al., 2004; Van Woesik et al., 2006). Parece que se fatores externos estimulam a liberação eles devem ser espécie-específicos (Harriott, 1983a) e que as espécies podem responder independentemente a esses fatores físicos com o objetivo de maximizar o seu sucesso reprodutivo (Babcock et al., 1986). Deste modo, se esses fatores físicos externos são diferentes e particulares para cada região e podem interferir na atividade reprodutiva do animal (como por exemplo, eventos de ressurgência, regimes de chuvas bem demarcados e intensos), é possível que o comportamento reprodutivo seja tão ou mais influenciado por esses fatores, quanto pela tsm.

Mendes \& Woodley (2002) não observaram nenhuma relação entre a época de liberação com o fato de a tsm estar aumentando, diminuindo ou no seu máximo em 
várias localidades estudadas. De fato, a temperatura absoluta no momento da liberação dos gametas variou consideravelmente, indo desde 23 até $32^{\circ} \mathrm{C}$. Dessa forma, os autores propuseram que a liberação não requereria um aumento, diminuição ou o máximo de tsm para acontecer, mas sim estar dentro de uma faixa ótima (com um valor mínimo abaixo do qual a liberação não ocorreria). Essa faixa ótima provavelmente deve variar dentro da mesma espécie que estão distribuídas em locais geograficamente distintos. Tanner (1996) propôs, por exemplo, que a temperatura ótima para a reprodução de $P$. damicornis no Havaí era de $26-27^{\circ} \mathrm{C}$ e que se ela excedesse em $1^{\circ} \mathrm{C}$ o assentamento de plânulas poderia cair rapidamente (Jokiel \& Guinther, 1978), e que populações coespecíficas de outras localidades provavelmente deveriam ter temperaturas ótimas diferentes. Assim, uma tsm ótima que varia de espécies para espécie e provavelmente também dentro da mesma espécie, deve ser necessária tanto para a maturação quanto para a liberação de gametas e plânulas (Harrison \& Wallace, 1990; Van Woesik et al., 2006).

Além do fotoperíodo, a irradiação solar e a pluviosidade também foram levantadas como fatores que seriam tão ou mais determinantes do que a tsm para a liberação de gametas/plânulas. Como discutido anteriormente, a irradiação solar deve influenciar na atividade reprodutiva do coral, uma vez que a zooxantela contida nele realiza a fotossíntese e fornece energia para suas atividades, inclusive para a reprodução. Van Woesik et al.. (2006) demonstrou que a liberação de doze espécies do Oceano Atlântico estava fortemente relacionada com os ciclos de irradiação solar que antecediam a liberação. Segundo os autores, a aclimatação às mudanças nas taxas de irradiação solar eram controladas fisiologicamente pelo coral, e que no período da liberação estes não conseguiam gerenciar adequadamente essas grandes mudanças de irradiação. Dessa forma, a época ótima para a liberação deveria ocorrer depois das mudanças mais altas nas taxas de irradiação solar terem passado, mas antes de ocorrerem as temperaturas extremas encontradas no pico do verão e do inverno. Níveis altos de irradiação solar são prejudiciais ao crescimento e funcionamento do fotossistema do simbionte (Jokiel \& York, 1984; Lesser, 1996) e podem causar danos teciduais aos pólipos das colônias (Siebeck, 1988). Alguns trabalhos de Diploria strigosa demonstraram que mesmo aumentos pequenos $\left(2^{\circ} \mathrm{C}\right) \mathrm{da}$ tsm podem diminuir a sobrevivência, a atividade ciliar (motilidade) a competência de assentamento das plânulas, principalmente, nos primeiros estágios de desenvolvimento da larva, ou ainda causar desenvolvimento embrionário aberrante (Bassim, 2002; Bassim \& Sammarco, 2003).

Desta maneira, talvez seja mais vantajoso para os corais liberarem gametas/plânulas em períodos quando conseguem gerenciar as mudanças das taxas 
de irradiação, e ao mesmo tempo, evitar possíveis danos às plânulas quando expostas à combinação de altas temperaturas e irradiação solar, no pico do verão. Uma outra idéia interessante para justificar a não planulação no pico da irradiação solar foi sugerida por Vermeij \& Bak (2002), que destacaram que os recrutas que assentassem durante a irradiação mínima anual, reduziriam a chance de escolherem uma "armadilha da morte", isto é, um habitat onde mais tarde ao longo do ano, a intensidade luminosa caísse, ficando abaixo do nível mínimo para a sobrevivência do coral. No entanto, Penland et al. (2004) observou que a liberação de gametas de várias espécies de corais ao longo do Pacífico Oeste $\left(30^{\circ} \mathrm{N}-30^{\circ} \mathrm{S}\right)$ ocorria sempre próximo aos períodos de irradiação máxima $\left(5,0-7,2 \mathrm{kWh} / \mathrm{m}^{2} / \mathrm{dia}\right)$, apesar da maior parte ter sido registrada um pouco antes ou um pouco depois dos valores máximos, raramente no pico de irradiação solar.

Observando o padrão da liberação de $M$. decactis da região de Ilha Grande constatamos que ele ocorre depois do pico de irradiação solar do verão em fevereiro $\left(6 \mathrm{kWh} / \mathrm{m}^{2} / \mathrm{dia}\right)$, próximo aos valores mínimos encontrados durante o ano (3,6-4 $\mathrm{kWh} / \mathrm{m}^{2} /$ dia), ficando bem abaixo dos níveis de irradiação que sinalizariam a liberação proposto por Penland et al. (2004). É provável que os valores ótimos de irradiação para a liberação também apresentem uma ampla variação, como ocorre com os valores de tsm, tornando-se necessário mais estudos sobre a relação entre a irradiação solar e a liberação em outras localidades.

Segundo Castro (1996), em águas costeiras de latitude média um dos mecanismos físicos que podem causar o aumento da estratificação da coluna d'água é a precipitação. Os resultados sobre o regime de chuvas do ambiente estudado indicam que no litoral sul fluminense, verificam-se os maiores índices pluviométricos do estado. A região possui um alto índice pluviométrico anual que não se distribui uniformemente durante o ano, concentrando-se na estação do verão. Março, abril e maio caracterizam-se como um período de transição entre os meses mais úmidos e os mais secos. Talvez esse regime pluviométrico bem demarcado e intenso, tenha um importante papel na determinação da época da liberação das plânulas de $M$. decactis da região. A liberação ocorre justamente no período de transição, quando a intensidade das chuvas diminui. Outros trabalhos também indicaram a pluviosidade como um possível fator determinante da época de liberação. Echinophora lamellosa presente no sul de Taiwan libera suas plânulas depois da época chuvosa caracterizada por tufões e chuvas intensas, evitando os períodos de alta turbidez e baixa salinidade, e talvez até se favorecendo do aumento de substratos disponíveis para o assentamento das plânulas gerado nesse período mais turbulento (Fan \& Dai, 1995). Porites porites de Barbados também libera seus gametas depois da estação 
chuvosa, permitindo o desenvolvimento da plânula em condições mais favoráveis (Tomascik \& Sander, 1987).

Mendes \& Woodley (2002) observaram que apesar do efeito da tsm ser maior que o das chuvas na determinação das liberações, sozinha, ela foi insuficiente para explicar a época da liberação. Eles encontraram dois padrões entre os eventos de liberação e de chuvas em 19 localidades estudadas: (1) a liberação nunca ocorria quando a pluviosidade mensal era muito alta e (2) em locais onde a variação da temperatura anual era muito pequena, a liberação ocorria antes do pico anual de pluviosidade. Assim, eles concluíram que a liberação dos corais era determinada para evitar a estação chuvosa, pois esta aumentaria dramaticamente o risco do sucesso reprodutivo devido à redução da salinidade na superfície da água. $\mathrm{A}$ baixa salinidade $\mathrm{e}$ muitas vezes, a alta turbidez causada pela intensa descarga de água doce e forte chuvas, podem atuar como um fator determinante no controle da distribuição de espécies de corais (Croz et al., 2005; Kregting \& Gibs, 2006). Experimentos em laboratório com plânulas de Montastrea faveolata demonstraram que o estresse ambiental causado pela redução da salinidade diminuiu a duração da fase de préassentamento, alterou a preferência por substratos naturais e aumentou as taxas de mortalidade. Sob condições adversas, os recursos energéticos da plânula parecem se esgotar mais rapidamente, o que reduziria a habilidade de selecionar sítios de assentamentos ótimos, alterando assim, a dinâmica da população (Vermeij et al., 2006).

Praticamente todos os estudos a respeito dos efeitos das condições ambientais sobre o ciclo reprodutivo dos corais são correlacionais, provavelmente porque a identificação dos mecanismos causais é geralmente muito difícil dada a constante variação do número de fatores ambientais que ocorrem às vezes de forma independente, às vezes com efeitos sinérgicos (Carey, 2005). Entretanto, quando as correlações apontam constantemente para um mesmo padrão, a preponderância da evidência pode ser convincente (Root et al., 2003), e é por isso que os diversos trabalhos de revisão compilam vários outros trabalhos com inúmeras espécies de localidades diferentes, na busca de se encontrar uma consistência para uma determinada associação observada (Carey, 2005). Desta maneira, o presente trabalho também utilizou observações correlacionais e algumas informações disponíveis dentro do vasto número de trabalhos envolvendo a reprodução de corais com o objetivo (talvez comum a todos os demais trabalhos) de entender um pouco mais sobre quais fatores estariam relacionados com o ciclo reprodutivo dessa espécie.

Desta forma, podemos dizer que o início do ciclo reprodutivo de Madracis decactis da llha Imboassica, provavelmente, deve estar relacionado com um ritmo 
endógeno (relógio biológico) que é influenciado por fatores exógenos caracterizados, principalmente, pelas mudanças da temperatura e/ou do fotoperíodo, de um padrão descendente para um ascendente. Como a temperatura é um fator fisiológico importante, ela deve ter um papel fundamental no controle da sazonalidade da reprodução (Oliver et al., 1988). O pico das atividades reprodutivas (produção e maturação dos gametas) ocorre, principalmente, durante o verão quando a produção (e a demanda) energética devem ser mais altas. Durante o inverno, os baixos níveis de irradiação solar podem ser insuficientes às demandas de energia dos corais se esses forem se reproduzir (Tanner, 1996). A periodicidade da liberação das plânulas está diretamente relacionada com o tempo de maturação dos gametas, que por sua vez depende de uma temperatura ótima espécie-específica que pode variar de região para região, e o tempo de incubação das plânulas que no caso de Madracis parece ser bastante curto. Além disso, ciclos de irradiação solar e regimes de pluviosidade também podem influenciar na época da liberação. No presente trabalho, ela acontece provavelmente entre os meses de abril e maio (meio/final do outono), depois do pico do verão, quando os valores de irradiação e tsm estão diminuindo, quando o período chuvoso está terminado, e antes dos valores mínimos de tsm e irradiação encontrados no inverno, proporcionando talvez, melhores chances de sobrevivência e sucesso reprodutivo para as plânulas de $M$. decactis.

\subsection{Considerações sobre os corais e os impactos ambientais}

Atualmente, os organismos marinhos estão sendo confrontados com distúrbios ambientais gerados pelo homem que estão se sobrepondo aos distúrbios naturais (Carey, 2005). A grande diferença entre as perturbações geradas pelo homem e as geradas pela natureza é que as últimas têm uma frequência pulsada e ocorrem de tempos em tempos (tempestades, tsunamis, terremotos, etc), enquanto que as primeiras, muitas vezes, têm um caráter contínuo e crônico que não dão tempo hábil para os organismos se recuperarem (Nyström et al., 2000). Essas perturbações crônicas incluem, por exemplo, a destruição de habitas, introdução de químicas no ambiente, introdução de espécies exóticas e aumento da irradiação UV, que comumente são encontradas juntas, atuando sinergicamente num mesmo habitat (Carey, 2005). Não bastasse isso, a rápida velocidade com que essas mudanças estão ocorrendo tem levantado a questão sobre a capacidade dos organismos de se adaptarem às condições não familiares em um curto período de tempo (Nyström et al., 2000; Root et al., 2003). Hughes et al. (2003) chamaram a atenção para a velocidade relativamente limitada de evolução dos corais e das zooxantelas de se adaptarem às novas temperaturas do mar, uma vez que são animais de vida longa, e que as 
diferenças geográficas na tolerância da temperatura que observamos hoje, devem ter evoluído durante um tempo muito maior do que os 10 anos das mudanças climáticas atuais.

Os efeitos negativos de alguns impactos na reprodução dos corais pode ter conseqüências dramáticas na sobrevivência de algumas espécies de corais. Altos níveis de nitrogênio e fósforo que geralmente estão presentes no esgoto doméstico alteraram a quantidade e o número de gametas de corais acroporídeos (Ward \& Harrison, 2000), e mesmo perturbações ambientais de curta duração podem levar ao aborto de parte das plânulas em desenvolvimento de Pocillopora damicornis (Jokiel, 1985). A eutrofização diminuiu a atividade reprodutiva de Porites porites através da redução dos níveis de luminosidade e/ou maior gasto adicional de energia para a remoção de material particulado (Tomascik \& Sander, 1987), além de reduzir o número de espaços adequados para o assentamento de corais levando a uma menor abundância de corais juvenis assentados nos recifes de Barbados (Hunte \& Wittenberg, 1992). Outros autores têm destacado a importância da época em que ocorrem os distúrbios, sugerindo que se os recifes forem afetados em períodos cruciais da gametogênese, liberação em massa, dispersão ou assentamento é provável que os efeitos negativos sobre tais espécies sejam potencializados (Kolinski \& Cox, 2003; Nyström et al., 2000).

Ao longo do período em que realizamos as coletas, observamos que a llha Imboassica, por apresentar um ambiente de águas rasas e relativamente calmo durante o ano todo, e por se localizar próximo à muitas pousadas que se encontram no lado oeste da Ilha Grande, recebe durante o pico do verão/primavera muitos barcos com escolas de mergulho com turistas mergulhadores já credenciados e alunos iniciantes para aulas de mar e batismo. A relativa proximidade da região com grandes cidades como São Paulo e Rio de Janeiro, o fácil acesso proporcionado pela rodovia Rio-Santos e pela estrutura portuária de Angra dos Reis, e é claro, a beleza natural da região tornam as ilhas da Baía de llha Grande, um dos destinos mais atrativos para mergulhadores e escolas de mergulho.

Alguns trabalhos têm discutido o efeito do turismo, mais precisamente, do mergulho turístico em ambientes recifais. A pouca flutuabilidade dos mergulhadores, a falta de aviso das escolas e operadoras de mergulho para os mergulhadores sobre os cuidados a serem tomados (e até o próprio desconhecimento dessas empresas sobre os impactos e danos potenciais de mergulhadores mal preparados) são alguns dos principais problemas observados nos recifes que são visitados pelos turistas (Harriott et al., 1997). A ressuspensão de sedimentos, a quebra de partes da colônia (Zakai \& Chadwick-Furman, 2002) e a abrasão de tecidos (Hawkins et al., 1999) são 
freqüentemente relatados como impactos importantes causados pelos mergulhadores. Estudos mostraram que corais expostos a curtos períodos de sedimentação (principalmente de grânulos do tamanho de siltes) são estressados, apresentam redução da produtividade e aumento da produção de muco sendo este bastante custoso ao animal (Riegl \& Bloomer, 1995; Weber et al., 2006). Zakai \& ChadwickFurman (2002) estudaram os efeitos dos mergulhos nos recifes de Eilat, Mar Vermelho, e estimaram que num mergulho típico de SCUBA de 60 minutos à 4-8m de profundidade, cada mergulhador quebrava de $1,7 \pm 4,9$ corais e ressuspendia $9,4 \pm 11,9$ nuvens de sedimentos sobre os recifes ( $n=251$ mergulhos). Apesar das formas maciças serem mais resistentes à quebra, a abrasão dos tecidos parece favorecer a susceptibilidade à doenças infecciosas resultando muitas vezes numa alta mortalidade e perda da cobertura desses corais (Hawkins et al., 1999; Tratalos, 2001). Em recifes onde prevalecem correntezas fortes, os mergulhadores atingem rapidamente a postura horizontal uma vez atingida a flutuação neutra. Dessa maneira, suas nadadeiras não tocam os recifes com muita freqüência e poucas quebras de colônia ou ressuspensão são observadas. Entretanto, parece que nessa situação, os mergulhadores muitas vezes usam as mãos protegidas por luvas para desviarem ou se segurarem em corais, principalmente quando vão tirar fotografias subaquáticas (Shleyer, 2000). Além dos impactos trazidos pelo mergulho em si, as próprias embarcações também podem causar muitos distúrbios aos ambientes turísticos com o lançamento indiscriminado de âncoras nos fundos dos recifes (Hawkins et al., 1999; Jameson et al., 1999; Tratalos, 2001).

Aparentemente, as colônias de Madracis decactis da Ilha Imboassica, assim como a comunidade bentônica em geral parecem estar saudável. Entretanto, mesmo níveis baixos de estresses crônicos podem ter impactos severos no recife ao longo do tempo, em termos de diminuição da reprodução e taxas de crescimento (Nyström et al., 2000). Por isso, estudos mais específicos a respeito do impacto dos mergulhos nesse ambiente se fazem necessários, principalmente porque o local é bastante utilizado para aulas de mergulho que geralmente geram muita ressuspensão de sedimentos, o que pode causar impactos negativos nas colônias de $M$. decactis, principalmente nos fragmentos pequenos (Bertuol, 1998). O impacto da ancoragem das embarcações no local parece não ser muito grande, uma vez que existem poitas onde normalmente os barcos se ancoram, apesar de na alta estação, o número de embarcações exceder o número de poitas disponíveis.

Davis (1995) fez uma observação interessante à cerca da relação entre os visitantes e os recifes de corais. Segundo o autor, por não ter um "preço ambiental" a ser pago pelos consumidores que se beneficiam do recife de coral intocado, este 
acaba ficando disponível por um preço muito baixo e pode, desta maneira, ser sobrecarregado. Para o autor, quando o livre acesso é o caso, os usuários individuais (mergulhadores) não são incentivados a conservação, e isso suporta a idéia de que a propriedade de todos torna-se a responsabilidade de ninguém.

A fórmula para que uma unidade de conservação consiga gerenciar os vários interesses e conflitos que normalmente ocorrem dentro dela não é simples e nem única. Mas, provavelmente, ela contém um ingrediente essencial: a integração e a colaboração das várias partes envolvidas como governo, empresas, comunidades regionais, instituições de pesquisas e ONGs. Quando essa integração acontece, as partes tão diferentes dialogam (mostram suas realidades, interesses e desejos na maioria das vezes conflitantes) e se consegue estabelecer um objetivo maior comum, podemos dizer que um enorme passo para sucesso da conservação e gerenciamento da unidade deve ter sido dado. Talvez o segredo desse sucesso esteja justamente na inversão da idéia discutida por Davis (1995), ou seja, a propriedade de todos torna-se responsabilidade de todos. E nesse contexto, a ciência tem muito a contribuir. Apesar, de muitos pesquisadores hesitarem em se envolver com a ciência "aplicada", bem como com a divulgação do conhecimento gerado para além do mundo acadêmico, hoje a urgência na tomada de decisões difíceis para o gerenciamento dos ecossistemas, torna a contribuição dos pesquisadores (biólogos, geógrafos, geólogos, físicos, químicos, etc) necessária e essencial (Wells, 1995). 


\section{6 - CONCLUSÕES}

- Duas formas de crescimento ocorrem na llha Imboassica: a forma nodular incrustante que se localiza em regiões bem iluminadas, e formas incrustantes mais achatadas que ocorrem geralmente em paredes verticais mais sombreadas.

- Madracis decactis da região de Ilha Grande, RJ, é hermafrodita. Os gametas masculinos e femininos ocorrem no mesmo lóculo gástrico, porém em mesentérios separados. Foram estabelecidos os estágios de desenvolvimento I, II e III para a ovogênese, e os estágios I, II, III e IV para a espermatogênese. A detecção e distinção dos estágios inicial e maduro do ovócito não foram tão claras.

- Nenhum embrião ou plânula foi observado nos cortes histológicos, apesar de estudos em outras localidades indicarem que a espécie seja incubadora de plânulas.

- O ciclo reprodutivo tem duração de cerca de sete meses. A ovogênese inicia-se em outubro e coincide com o início do aumento da temperatura do mar. A duração da espermatogênese é mais curta (três meses) e tem início no final de fevereiro. Apesar da assincronia inicial, a ovogênese e a espermatogênese tornam-se sincronizadas nos últimos meses. O pico da atividade reprodutiva ocorre no final do verão e meio do outono (entre fevereiro e abril), quando todos os pólipos apresentam-se férteis com ovócitos e espermatócitos em estágios maduros.

- A época de liberação das plânulas deve ocorrer entre maio e abril (meio/final do outono) no período de transição entre maior e menor pluviosidade e depois de passado o pico da temperatura da água e da irradiação solar, mas antes dos valores mínimos encontrados no inverno.

- Apesar das colônias de M. decactis e os demais organismos apresentarem-se aparentemente saudáveis na llha Imboassica, é importante que se discutam os possíveis impactos do turismo, principalmente das atividades de mergulhos, que até o momento parecem não sofrer nenhuma regulamentação ou monitoramento bem como nenhuma orientação educacional por parte da Estação Ecológica de Tamoios. 


\section{7 - REFERÊNCIAS}

Acosta, A. \& Zea, S., 1997. Sexual reproduction on the reef coral Montastrea cavernosa (Scleractinia: Faviidae) in the Santa Marta area, Caribbean cost of Colombia. Marine Biology, 128: 141-148.

Ayre, D.J. \& Willis, B.L., 1988. Population structure in the coral Pavona cactus: clonal genotypes show little phenotypic plasticity. Marine Biology, 99: 495-505.

Babcock, R.C., 1988. Fine-scale spatial and temporal patterns in coral settlement. Proceedings of the $6^{\text {th }}$ International Coral Reef Symposium, 2: 635-639.

Babcock, R.C., Willis, B.L. \& Simpson, C.J., 1994. Mass spawning of corals on a high latitude coral reefs. Coral Reefs, [online]. 13, Abstract extraído do banco de dados de Springer Berlin/Heidelberg

Disponível

em:

http://www.springerlink.com/content/m34I3w826737u226/?p=7c490d13b2aa46b597e3

a379ff88baae\&pi $=4$

[acessado em 25 de maio de 2007]

Babcock, R.C., Bull, G.D., Harrison, P.L., Heyward, A.J., Oliver, J.K., Wallace, C.C. \& Willis, B.L., 1986. Synchronous spawning of 105 scleractinian coral species on the Great Barrier Reef. Marine Biology, 90: 379-394.

Baird, A.H., Babcock, R.C. \& Mundy, C.P., 2003. Habitat selection by larvae influences the depth distribution of six common coral species. Marine Ecology Progress Series, 252: 289-293.

Bak, R.P.M. \& Engel, M.S., 1979. Distribution, abundance and survival of juvenile hermatypic corals (Scleractinia) and the importance of life history strategies in the parent coral community. Marine Biology, 54: 341-352.

Bassim, K.M. \& Sammarco, P.W., 2003. Effects of temperature and ammonium on larval development and survivorship in a scleractinian coral (Diploria strigosa). Marine Biology, 142: 241-252.

Bassim, K.M., Sammarco, P.W. \& Snell, T.L., 2002. Effects of temperature on success of (self and non-self) fertilization and embriogenesis in Diploria strigosa (Cnidaria, Scleractinia). Marine Biology, 140: 479-488.

Ben Tzvi, O., Einbinder, S. \& Brokovich, E., 2006. A beneficial association between a polychaete worm and scleractinian coral? Coral Reefs, 25: 88.

Bertuol, P.R.K., 1998. Impacto de mergulhadores sobre colônias de corais - Ilha das Galés - Santa Catarina. Monografia de conclusão de curso. Centro de Ciências Biológicas da Universidade Federal de Santa Catarina.

Bradshaw, A.D., 1965. Evolutionary significance of phenotipic plasticity in plants. Advances in Genetics, 13: 115-155.

Bruno, J.F. \& Edmunds, P.J., 1997. Clonal variation for phenotypic plasticity in the coral Madracis mirabilis. Ecology, 78 (7): 2177-2190.

1998. Metabolic consequences of phenotypic plasticity in the coral Madracis mirabilis (Duchassaing and Michelotti): the effect of morphology and water flow on aggregate respiration. Journal of Experimental Marine Biology and Ecology, 229: 187-195.

Cairns, S.D., 1999. Species richness of recent Scleractinia. Atoll Research Bulletin, 459: 1-12.

Cairns, S.D., Hoeksema, W. \& Van der Land, J., 1999. List of extant stony corals. Atoll Research Bulletin, 459: 13-45.

Calderon, E.M., Castro, C.B. \& Pires, D.O., 2000. Natação, assentamento e metamorfose de plânulas do coral Favia gravida Verril, 1868 (Cnidaria, Scleractinia). Boletim do Musue Nacional, Nova Série, Rio de Janeiro, 429: 112. 
Campbell, R.D., 1974. III Cnidaria. In A.C. Giese \& J.S. Pearse, eds. Reproduction of marine invertebrates v. 1. Acoelomate and Pseudocoelomate. New York: Academic Press, 1974.

Carey, C., 2005. How physiological methods and concepts can be useful in conservation biology? Integrative and Comparative Biology, 45: 4-11.

Castro, B.M., Lorenzzetti, J.A., Silveira, I.C.A. \& Miranda, L.B., 2006. Estrutura termohalina e circulação na região entre o Cabo de São Tomé (RJ) e Chuí (RS). In C.L.B.R. Rossi-Wongtschowski, \& L.S.P. Madureira, eds. O Ambiente Oceanográfico da plataforma continental e do talude na região sudeste-sul do Brasil: São Paulo: Edusp, 2006.

Castro, B.T. \& Pires, D.O., 2006. Reproductive biology of Madracis decactis (Lyman, 1859) (Cnidaria, Scleractinia) from southern Bahia reefs, Brazil. Arquivos do Museu Nacional, Rio de Janeiro, 64 (1): 19-27.

Castro, C.B. \& Pires, D.O., 2001. Brazilian coral reefs: what we already know and what is still missing. Bulletin of Marine Science, 69 (2): 357-371.

Castro Filho, B.M., 1996. Correntes e massas de água da Plataforma Continental Norte de São Paulo. Tese de Livre Docência. Instituto Oceanográfico da Universidade de São Paulo.

Couto, E.C.G., Silveira, F.L.D. \& Rocha, G.R.A., 2003. Marine Biodiversity in Brazil: the currents status. Gayana, 67 (2): 327-340.

Creed, J.C., 2006. Two invasive alien azooxanthellate corals: Tubastrea coccinea and Tubastrea tagusensis, dominate the native zooxanthellate coral Mussismila hispida in Brazil. Coral Reefs, 25 (3): 350.

Croz, L.D., Rosario, J.B.D. \& Góndola, P., 2005. The effect of fresh water runoff on the distribution of dissolved inorganic nutrients and plankton in the Bocas Del Toro Arquipelago, Caribbean Panama. Caribbean Journal of Science, 41 (3): 414429.

Davis, D. \& Tisdell. C., 1995. Recreational scuba-diving and carry capacity in marine protected areas. Ocean \& Coastal Management, 26 (1): 19-40.

De Paula, A.F. \& Creed, J.C., 2004. Two species of coral Tubastrea (Cnidaria, Scleractinia) in Brazil: a case of accidental introduction. Bulletin of Marine Science, 74 (1): 175-183.

Delvoye, L., 1988. Gametogenesis and gametogenic cycles in Agaricia agaricites (L) and Agaricia humilis Verril and notes on gametogenesis in Madracis mirabilis (Duchassaing \& Michelotti) (Scleractinia). Uitgaven. Natuurwetenschappelijke Studiekring Voor Suriname em de Nederlanddse Antillen, 123: 101-134.

DeVantier, L.M. \& Endean, R., 1989. Observations of colony fission following ledge formation in massive reef corals of the genus Porites. Marine Ecology Progress Series, 58: 191-195.

Diekmann, O.E., Bak, R.P.M., Stam, W.T. \& Olsen, J.L., 2001. Molecular genetic evidence for probable reticulate speciation in the coral genus Madracis from a Caribbean fringing reef slope. Marine Biology, 139: 221-233.

Diekmann, O.E., Olsen, J.L., Stam, W.T. \& Bak, R.P.M., 2003. Genetic variation in Symbiodinium clade B from the coral genus Madracis in the Caribbean (Netherlands Antilles). Coral Reef, 22: 29-33.

Diekmann, O.E., Bak, R.P.M., Tonk, L., Stam, W.T. \& Olsen, J.L., 2002. No habitat correlation of zooxanthellae in the coral genus Madracis on a Curaçao reef. Marine Ecology Progress Series, 227: 221-232.

Done, T.J. \& Potts, D.C., 1992. Influences of habitat and natural disturbances on contributions of massive Porites corals to reef communities. Marine Biology, 114: 479-493.

Dunstan, P.K. \& Johnson, C.R., 1998. Spatio-temporal variation in coral recruitment at different scales at Heron Reef, southern Great Barrier Reef. Coral Reefs, 17: 71-81. 
Edmunds, P.J. \& Davies, O.S., 1986. An energy budget for Porites porites (Scleractinia). Marine Biology, 92: 339-347.

Fadlallah, Y.H., 1985. Reproduction in the coral Pocillopora verrucosa on the reefs adjacent to the industrial city of Yanbu (Red Sea, Saudi Arabia). Proceeding of the $5^{\text {th }}$ Coral Reef Congress, 4: 313-318.

Fadlallah, Y.H. \& Pearse, J.S., 1982. Sexual reproduction in solitary corals: overlapping oogenic and brooding cycles, and benthic planulas in Balanophyllia elegans. Marine Biology, 71: 223-231.

Fan, T.Y. \& Dai, C.F., 1995. Reproductive ecology of the scleractinian coral Echinopora lamellosa in the northern and southern Taiwan. Marine Biology, 123: 565-572. 1998. Sexual reproduction of the scleractinian coral Merulina ampliata in southern Taiwan. Bulletin of Marine Science, 62 (3): 897-904.

Fenner, D.P., 1993. Species distinctions among several Caribbean corals. Bulletin of Marine Science, 53 (3): 1099-1116.

Francini, C.L.B., Castro, C.B. \& Pires, D.O., 2002. First record of a reef coral spawning event in the western South Atlantic. Invertebrate Reproduction and Development, 42 (1): 17-19.

Glynn, P.W., Gassman, N.J., Eakin, C.M., Cortés, J., Smith, D.B. \& Guzman, H.M., 1991. Reef coral reproduction in the eastern Pacific: Costa Rica, Panama, and Galapagos Islands (Ecuador). I. Pocilloporidae. Marine Biology, 109: 355-368.

Glynn, P.W., Colley, S.B., Eakin, C.M., Smith, D.B., Cortés, J., Gassman, N.J., Guzmán, H.M., Del Rosario, J.B. \& Feingold, J.S., 1994. Reef coral reproduction in the eastern Pacific: Costa Rica, Panamá, and Galápagos Islands (Ecuador). II. Poritidae. Marine Biology, 118: 191-208.

Goffredo, S., Arnone, S. \& Zaccanti, F., 2002. Sexual reproduction in Mediterranean solitary coral Balanophyllia europaea (Scleractinia, Dendrophylliidae). Marine Ecology Progress Series, 229: 83-94.

Goffredo, S., Radeti, J., Airi, V. \& Zaccanti, F., 2005. Sexual reproduction of the solitary sunset cup coral Leptopsammia pruvoti (Scleractinia: Dendrophylliidae) in the Mediterranean. 1. Morphological aspects of gametogenesis and ontogenesis. Marine Biology, 147 (2): 485-495.

Harii, S., Omori, M., Yamakawa, H. \& Koike, Y., 2001. Sexual reproduction and larval settlement of the zooxanthellate coral Alveopora japonica Eguchi at high latitudes. Coral Reefs, 20: 19-23.

Harii, S., Kayanne, H., Takigawa, H., Hayashibara, T. \& Yamamoto, M., 2002. Larval survivorship, competency period and settlement of two brooding corals, Heliopora coerulea and Pocillopora damicornis. Marine Biology, 141: 39-46.

Harriott, V.J., 1983a. Reproductive ecology of four scleractinian species at Lizard Island, Great Barrier Reef. Coral Reefs, 2: 9-18. 1983b. Reproductive seasonality, settlement, and post-settlement mortality of Pocillopora damicornis (Linnaeus), at Lizard Island, Great Barrier Reef. Coral Reefs, 2: 151-157.

Harriott, V.J. \& Banks, A.S., 1995. Recruitment of scleractinian corals in the Solitary Islands Marine Reserve, a high latitude coral-dominated community in Eastern Australia. Marine Ecology Progress Series, 123: 155-161.

2002. Latitudinal variation in coral communities in eastern Australia: a qualitative biophysical model of factors regulating coral reefs. Coral Reefs, 21: 83-94.

Harriott, V.J., Davis, D. \& Banks, A.S., 1997. Recreational diving and its impact in marine protected areas in Eastern Australia. Ambio, 26 (3): 173-179.

Harrison, P.L., 1985. Sexual characteristics of scleractinian corals: systematic and evolutionary implications. Proceedings of the $5^{\text {th }}$ International Coral Reef Congress, 4: 337-342. 
Harrison, P.L. \& Wallace, C.C., 1990. Reproduction, dispersal and recruitment of scleractinian corals. In Z. Dubinsky, ed. Coral Reefs, Ecosystems of the World 25. Amsterdam; New York: Elsevier Science.

Hawkins, J.P., Roberts, C.M., Van't Hof, T., Meyer, K.D., Tratalos, J. \& Aldam, C., 1999. Effects of recreational scuba diving on Caribbean coral and fish communities. Conservation Biology, 13 (4): 888-897.

Hayashibara, T., Shimoike, K., Kimura, T., Hosaka, S., Heyward, A., Harrison, P.L., Kudo, K. \& Omori, M., 1993. Patterns of coral spawning at Akajima Island, Okinawa, Japan. Marine Ecology Progress Series, 101: 253-262.

Hetzel, B. \& Castro, C.B., 1994. Corais do sul da Bahia. Rio de Janeiro: Ed. Nova Fronteira

Hetzel, O.S. \& Babcock, R.C., 2002. Sexual reproduction, larval development and benthic planulae of solitary coral Monomyces rubrum (Scleractinia: Anthozoa). Marine Biology, 140: 659-667.

Heyward, A.J. \& Babcock, R.C., 1986. Self- and cross-fertilization in scleractinian corals. Marine Biology, 90: 191-195.

Highsmith, R.C., 1980. Passive colonization and asexual colony multiplication in the massive coral Porites lutea Milne Edwards \& Haime. Journal of Experimental Biology and Ecology, 47: 55-67.

1981. Coral Bioerosion at Enewetak: agents and dynamics. Internationale Revue der Gesamten Hydrobiogie, 66 (3): 335-375.

1982. Reproduction by fragmentation in corals. Marine Ecology Progress Series, 7: 207-226.

Highsmith, R.C., Lueptow, R.L. \& Schonberg, S.C., 1983. Growth and bioerosion of three massive corals on the Belize barrier reef. Marine Ecology Progress Series, 13: 261-271.

Hughes, T.P., Baird, A.H., Dinsdale, E.A., Harriott, V.J., Moltschaniwskyj, N.A., Pratchett, M.S., Tanner, J.E. \& Willis, B.L., 2002. Detecting regional variation using meta-analysis and large-scale sampling: latitudinal patterns in recruitment. Ecology, 83 (2): 436-451.

Hughes, T.P., Baird, A.H., Bellwood, D.R., Card, M., Connolly, S.R., Folke, C., Grosberg, R., Hoegh-Guldberg, O., Jackson, J.B.C., Kleypas, J., Lough, J.M., Marshall, P., Nyström, M., Palumbi, S.R., Pandolfi, J.M., Rosen, B. \& Roughgarden, J., 2003. Climate change, human impacts, and the resilience of coral reefs. Science, 301: 929-933.

Hunte, W. \& Wittenberg, M., 1992. Effects of eutrophication and sedimentation on juveniles corals. Marine Biology, 114: 625-631.

Idijadi, J.A. \& Edmunds, P.J., 2006. Scleractinian corals as facilitators for other invertebrates on a Caribbean reef. Marine Ecology Progress Series, 319: 117127.

Isomura, N. \& Nishihira, M., 2001. Size variation of planulae and its effect on the lifetime of planulae in three pocilloporid corals. Coral Reefs, 20: 309-315.

Jameson, S.C., Ammar, M.S.A., Saadalla, E., Mostafa, H.M. \& Riegl, B., 1999. A coral damage index and its application to diving sites in the Egyptian Red Sea. Coral Reefs, 18: 333-339.

Jokiel, P.L., 1985. Lunar periodicity of planula release in the reef coral Pocillopora damicornis in relation to various environment factors. Proceedings of the $5^{\text {th }}$ International Coral Reef Congress, 4: 307-312.

Jokiel, P.L. \& Guinther, E.B., 1978. Effects of temperature on reproduction in the hermatypic coral Pocillopora damicornis. Bulletin of Marine Science, 28: 786789.

Jokiel, P.L. \& York, R.H., 1984. Importance of ultraviolet radiation in photoinhibition of microalgal growth. Limnology and Oceanography, 29 (1): 192-199.

Kinzie III, R.A., 1996. Modes of speciation and reproduction in archaeocoeniid corals. Galaxea, 13: 47-64. 
Kitahara, M.V. \& Cairns, S.D., 2005. Monohedrotochus capitolii, a new genus and species of solitary azooxanthellate coral (Scleractinia, Caryophylliidae) from southern Brazil. Zoologische Mededelingen Leiden, 79 (5): 115-121.

Knowlton, N., Maté, J.L., Guzmán, H.M., Rowan, R. \& Jara, J., 1997. Direct evidence for reproductive isolation among the three species of the Montastrea annularis complex in Central America (Panamá and Honduras). Marine Biology, 127: 705711.

Kojis, B.L., 1986. Sexual reproduction in Acropora (Isopora) (Coelenterata: Scleractinia). II. Latitudinal variation in A. palifera from the Great Barrier Reef and Papua New Guinea. Marine Biology, 91: 311-318.

Kojis, B.L. \& Quinn, N.J., 1981a. Aspects of sexual reproduction and larval development in the shallow water hermatypic coral, Goniastrea australiensis (Edwards and Haime, 1857). Bulletin of Marine Science, 31 (3): 558-573. 1981b. Reproductive strategies in four species of Porites (Scleractinia). Proceedings of the $4^{\text {th }}$ International Coral Reef Symposium, 2: 145-151.

Kolinski, S.P. \& Cox, E.F., 2003. An update on modes and time of gamete and planulae release in Hawaiian scleractinian corals with implications for conversation and management. Pacific Science, 57 (1): 17-27.

Kregting, L.T. \& Gibbs, M.T., 2006. Salinity controls the upper depth limit of black corals in Doubtful Sound, New Zealand. New Zealand Journal of Marine and Freshwater Research, 40: 43-52.

Kruger, A. \& Schleyer, M.H., 1998. Sexual reproduction in the coral Pocillopora verrucosa (Cnidaria: Scleractinia) in KwaZulu-Natal, South Africa. Marine Biology 132: 703-710

Laborel, J.L., 1967. A revised list of Brazilian scleractinian corals and description of a new species. Postilla Yale Peabody Museum, 107: 1-14.

1969/70. Madréporaires et hydrocoralliaires récifaux des cotes brésiliennes: Systematique, écologie, répartition verticale et géographique. Campagne de la Calypso au large des cotes atlantiques de l'Amérique du Sud. Annales de l'institut Oceanographique, 47 (9): 15-229.

Lam, K.K.Y., 2000. Sexual reproduction of a low-temperature tolerant coral Oulastrea crispata (Scleractinia, Faviidae) in Hong Kong, China. Marine Ecology Progress Series, 205: 101-111.

Leão, Z.M.A.N., 1999. Abrolhos, BA: O complexo recifal mais extenso do Atlântico Sul. In C. Schobbenhaus, D.A. Campos, E.T. Queiroz, M. Winge \& M.L.C. BerbertBorn, eds. Sítios Geológicos e Paleontológicos do Brasil. [online]

Disponível em: http://www.unb.br/ig/sigep/sitio090/sitio090.htm [acessado em 25 de maio de 2007]

Leão, Z.M.A.N., Kikuchi, R.P. \& Testa, V., 2003. Coral and coral reefs of Brazil. In J. Cortés, ed. Latin American coral reefs. Elsevier Science

Lesser, M.P., 1996. Elevated temperatures and ultraviolet radiation cause oxidative stress and inhibit photosynthesis in symbiotic dinoflagellates. Limnology and Oceanography, 41 (2): 271-283.

Lewis, J.B., 1974. The settlement behavior of planulae larvae of the hermatypic coral Favia fragum (Esper). Journal of Experimental Marine Biology and Ecology, 15: 165-172.

Lins de Barros, M. \& Pires, D.O., 2007. Comparison of the reproductive status of the scleractinian coral Siderastrea stellata throughout the gradient of $20^{\circ}$ of latitude. Brazilian Journal of Oceanography, 55 (1): 67-69.

Lins de Barros, M., Pires, D.O. \& Castro, C.B., 2003. Sexual reproduction of the Brazilian reef coral Siderastrea stellata Verril 1868 (Anthozoa, Scleractinia). Bulletin of Marine Science, 73 (3): 713-724.

Maclean, N. \& Hall, B.K., 1987. Cell commitment and differentiation. Cambrigde [Cambrigdeshire]; New York: Cambridge University Press 
Mahiques, M. \& Furtado, V.V., 1989. Utilização da análise dos componentes principais na caracterização dos sedimentos de superfície e de fundo da Baía de Ilha Grande (RJ). Boletim do Instituto Oceanográfico, 37 (1): 1-19.

Maida, M. \& Ferreira, B.P., 1995. Estudo preliminar sobre o assentamento de corais em um recife na Baía de Tamandaré - PE. Boletim Técnico Científico do CEPENE, 3 (1): 37-48.

McGuire, M.P., 1998. Timing for larval release by Porites astreoides in the northern Florida Keys. Coral Reefs, 17: 369-375.

Mendes, J.M. \& Woodley, J.D., 2002. Timing of reproduction in Montastrea annularis: relationship to environmental variables. Marine Ecology Progress Series, 227: 241-251.

Miller, K.J. \& Ayre, D.J., 2004. The role of sexual and asexual reproduction in structuring high latitude populations of the reef coral Pocillopora damicornis. Heredity, 92: 557-568.

Ministério do Meio Ambiente, 2000. Plano de Manejo do Parque Nacional da Serra da Bocaina [online]

Disponível em: http://www.paraty.com.br/bocaina/pdf/anexo52.pdf [acessado em 25 de maio de 2007]

2006. Plano de Manejo da Estação Ecológica de Tamoios. [Cd]. Rio de Janeiro

Miranda, L.B., 1982. Análise de massas de águas da plataforma continental e da região oceânica adjacente: Cabo de São Tomé (RJ) à Ilha de São Sebastião $(S P)$. Tese de Livre Docência. Instituto Oceanográfico da Universidade de São Paulo.

Morandini, A.C., 1999. Gametogênese e desenvolvimento embrionário de Nausithoe aurea (Scyphozoa, Coronate) do Canal de São Sebastião - SP. Dissertação de Mestrado. Instituto de Biociências da Universidade de São Paulo.

Morandini, A.C. \& Silveira, F.L., 2001. New observations and new record of Nausithoe aurea (Scyphozoa, Coronate). Papéis Avulsos de Zoologia, 41 (27): 519-527.

Muko, S., Kawasaki, K., Sakai, K., Takasu, F. \& Shigesada, N., 2000. Morphological plasticity in the coral Porites sillimaniani and its adaptative significance. Bulletin of Marine Science, 66 (1): 225-239.

Muscatine, L., Falkowski, P.G., Porter, J.W. \& Dubinsky, Z., 1984. Fate of photosynthetic fixed carbon in light- and shade-adapted colonies of the symbiotic coral Stylophora pistillata. Proceedings of the Royal Society of London (Series B), 222: 181-202.

Nakano, Y. \& Yamazato, K., 1992. Ecological study of reproduction of Oulastrea crispata in Okinawa. Zoological Science, 9: 1292

Neves, E.G., 2004. Complexo Siderastrea: espécies distintas? Significado da variabilidade do gênero Siderastrea de Blainville, 1830 (Anthozoa, Scleractinia) no Brasil. Tese de doutorado. Instituto de Biociências da Universidade de São Paulo.

Neves, E.G., Johnsson, R., Sampaio, C. \& Pichon, M., 2006. The occurrence of Scolymia cubensis in Brazil: revising the problem of the Caribbean solitary mussids. Zootaxa, 1366: 45-54.

Neves, E.G. \& Pires, D.O., 2002. Sexual reproduction of Brazilian coral Mussismilia hispida. Coral Reefs, 21: 161-168.

Neves, E.G., Silveira, F.L.D., Johnsson, R. \& Longo, L.L., 2002. Shallow-water scleractinian corals and zoanthids from reefs of Coroa Grande, Pernambuco state, Brazil. Biociências, 10 (2): 127-145.

Neogene Marine Biota of Tropical America (NMITA) [online]. (última atualização em 10 setembro de 2004)

Disponível em:

http://eusmilia.geology.uiowa.edu/database/corals/combined/Madracis.htm

[acessado em 25 de maio de 2007] 
Nogueira, J.M.M., 2000. Anelídeos poliquetas associados ao coral Mussismilia hispida (Verrill, 1868) em ilhas do litoral do Estado de São Paulo. Phyllodocida, Amphinomida, Eunicida, Spionida, Terebellida e Sabellida. Tese de Doutorado. Instituto de Biociências da Universidade de São Paulo.

2003. Fauna living in colonies of Mussismilia hispida (Verrill) (Cnidaria: Scleractinia) in four south-eastern Brazil Islands. Brazilian Archives of Biology and Technology, 46 (3): 421-432.

Nozawa, Y., Tokeshi, M. \& Nojima, S., 2006. Reproduction and recruitment of scleractinian coral in a high-latitude coral community, Amakusa, southwestern Japan. Marine Biology, 149: 1047-1058.

Nyström, M., Folk, C. \& Moberg, F., 2000. Coral reef disturbance and resilience in a humam-dominated environment. Tree, 15 (10): 413-417.

Oigman-Pszczol, S.S., Oliveira, A.E.S. \& Creed, J.C., 2007. Perceptions of coral in a coastal tourist town in Brazil. Coral Reefs, [online]. 26,

Disponível

em:

http://www.springerlink.com/content/36667701v4093w27/fulltext.pdf [acessado em 25 de maio de 2007]

Olive, P.J.W. \& Garwood, P.R., 1983. The importance of long term endogenous rhythms in the maintenance of reproductive cycles of marine invertebrates: a reappraisal. International Journal of Invertebrate Reproduction, 6: 339-347.

Oliver, J.K., Babcock, R.C., Harrison, P.L. \& Willis, B.L., 1988. Geographic extent of mass coral spawning: clues to ultimate casual factors. Proceedings of the $6^{\text {th }}$ International Coral Reef Symposium, 2: 803-810.

Pearse, J.S., 1974. Reproductive patterns of tropical reef animals: three species of sea urchins. Proceedings of the $2^{\text {nd }}$ International Coral Reef Symposium, 1: 235240.

Pedro Junior, M.J., Alfonsi, R.R., Camargo, M.B.P., Chiavegatto, O.M.D.P., Ortolani, A.A. \& Brunini, O., 1989. Disponibilidade de radiação solar global para o Estado de São Paulo. Boletim Técnico do Instituto Agronômico, 123.

Penland, L., Koulechad, J., Idip, D. \& Van Woesik, R., 2004. Coral spawning in the western Pacific Ocean is related to solar insolation: evidence of multiple spawning events in Palau. Coral Reefs, 23: 133-140.

Perry, C.T. \& Lacombe, P., 2003. Marginal and non-reef-building coral environments. Coral Reefs, 22: 427-432.

Pires, D.O., 1995. Cnidoma da ordem Scleractinia (Cnidaria, Anthozoa). Tese de Doutorado. Instituto de Biociências da Universidade de São Paulo.

Pires, D.O. \& Caparelli, A.C., 2002. Biologia reprodutiva de Porites astreoides Lamarck, 1816 (Cnidaria, Scleractinia) do Complexo Recifal dos Abrolhos, BA, Brasil. Boletim do Museu Nacional, 484: 1-12.

Pires, D.O., Castro, C.B. \& Ratto, C.C., 1999. Reef coral reproduction in the Abrolhos Reef Complex, Brazil: the endemic genus Mussismilia. Marine Biology, 135: 463-471.

, 2002. Reproduction of the solitary coral Scolymia wellsi Laborel (Cnidaria, Scleractinia) from the Abrolhos Reef Complex, Brazil. Proceedings of the $9 t^{\text {h }}$ International Coral Reef Symposium, 1: 381-384.

Reynolds, R.W., Casey, K.S., Smith, T.M. \& Chelton, D.B., 2006. A daily blended analysis for sea surface temperature. $14^{\text {th }}$ Conference on Satellite Meteorology and Oceanography [online]

Disponível

http://ams.confex.com/ams/Annual2006/techprogram/paper_100704.htm

em: [acessado em 25 de maio de 2007]

Reynolds, R.W., Rayner, N.A., Smith, T.M., Stokes, D.C., Wang, W., 2002. An improved in situ and satellite SST analysis for climate. Journal of Climate, 15: 1609-1625. 
Richmond, R.H., 1987. Energetics, competency, and long-distance dispersal of planula larvae of the coral Pocillopora damicornis. Marine Biology, 93: 527-533.

Richmond, R.H. \& Hunter, C.L., 1990. Reproduction and recruitment of corals: comparisons among the Caribbean, the Tropical Pacific, and the Red Sea. Marine Ecology Progress Series, 60: 185-203.

Riegl, B. \& Bloomer, J.P., 1995. Tissue damage on scleractinian and alcyonacean corals due to experimental exposure to sedimentation. Beiträge zur Paläontologie, 20: 51-63.

Rinkevich, B., 1989. The contribution of photosynthetic products to coral reproduction. Marine Biology, 101: 259-263.

Rinkevich, B. \& Loya, Y., 1979. The reproduction of the Red Sea coral Stylophora pistillata I. Gonads and Planulae. Marine Ecology Progress Series, 1: 133-144.

Root, T.L., Price, J.T., Hall, K.R., Schneider, S.H., Rosenzweig, C. \& Pounds, A., 2003. Fingerprints of global warming on wild animal and plants. Nature, 421: 57-60.

Sakai, K., 1997. Gametogenesis, spawning, and planula brooding by the reef coral Goniastrea aspera (Scleractinia) in Okinawa, Japan. Marine Ecology Progress Series, 151: 67-72.

Sammarco, P.W. \& Risk, M.J., 1990. Large-scale patterns in internal bioerosion of Porites: cross continental shelf trends on the Great Barrier Reef. Marine Ecology Progress Series, 59: 145-156.

Secretaria do Meio Ambiente do Estado do Rio de Janeiro, 2001. Atlas das Unidades de Conservação da natureza do Estado do Rio de Janeiro. São Paulo: Ed. Metalivros.

Sherman, C.D.H., Ayre, D.J. \& Miller, K.J., 2005. Asexual reproduction does not produce clonal populations of the brooding coral Pocillopora damicornis on the Great Barrier Reef, Australia. Coral Reefs, 25: 7-18.

Shlesinger, Y., Goulet, T.L. \& Loya, Y., 1998. Reproductive patterns of scleractinian corals in the northern Red Sea. Marine Biology, 132: 691-701.

Shlesinger, Y. \& Loya, Y., 1985. Coral community reproductive patterns: Red Sea versus the Great Barrier Reef. Science, 228 (4705): 1333-1335.

Shleyer, M.H. \& Tomalin, B.J., 2000. Damage on south African coral reefs and an assessment on their sustainable diving capacity using a fisheries approach. Bulletin of Marine Science, 67 (3): 1025-1042.

Siebeck, O., 1988. Experimental investigation of UV tolerance in hermatypic corals (Scleractinia). Marine Ecology Progress Series, 43: 95-103.

Sier, C.J.S. \& Olive, P.J.W., 1994. Reproduction and reproductive variability in the coral Pocillopora verrucosa from the Republic of Maldives. Marine Biology, 118: 713-722.

Signorini, S.R., 1980. A study of the circulation in bay of Ilha Grande and bay of Sepetiba. Part I: a survey of the circulation based on experimental field data. Boletim do Instituto Oceanográfico, 29 (1): 41-55.

Soares, F.S., 2005. Distribuição espacial da precipitação na região hidrográfica da Baía da llha Grande e área de entorno (RJ). Monografia de conclusão de curso. Instituto de Geociências da Universidade Federal Fluminense.

Soares, F.S., Francisco, C.N., Carvalho, C.N.D., 2005. Análise dos fatores que influenciam a distribuição espacial da precipitação no litoral sul fluminense, RJ. Anais XII Simpósio Brasileiro de Sensoriamento Remoto: 3365-3370.

Soong, K., 1991. Sexual reproductive patterns of shallow-water reef corals in Panama. Bulletin of Marine Science, 49 (3): 832-846.

Species 2000, 2007. Catalogue of Life: 2007 Annual Checklist [online]. Disponível em: http://www.catalogueoflife.org/annual-checklist/2007/search.php [acessado em 25 de maio de 2007]

Stimson, J.S., 1978. Mode and timing of reproductive on some common hermatypic corals of Hawaii and Enewetak. Marine Biology, 48: 173-184. 
Stoddart, J.A., 1983. Asexual production of planulae in the coral Pocillopora damicornis. Marine Biology, 76: 279-284.

Stoddart, J.A. \& Black, R., 1985. Cycles of gametogenesis and planulation in the coral Pocillopora damicornis. Marine Ecology Progress Series, 23: 153-164.

Szmant, A.M., 1986. Reproductive ecology of Caribbean reef corals. Coral Reefs, 5: 43-53.

1991. Sexual reproduction by the Caribbean reef corals Montastrea annularis and M. cavernosa. Marine Ecology Progress Series, 74: 13-25.

Szmant-Froelich, A.M, Reutter, M. \& Riggs, L., 1985. Sexual reproduction of Favia fragum (esper): lunar patterns of gametogenesis, embriogenesis and planulation in Puerto Rico. Bulletin of Marine Science, 37 (3): 880-892.

Szmant-Froelich, A.M., Yevich, P. \& Pilson, M.E.Q., 1980. Gametogenesis and early development of the temperate coral Astrangia danae (Anthozoa: Scleractinia). Biological Bulletin, 158: 257-269.

Tanner, J.E., 1996. Seasonality and lunar periodicity in the reproduction of Pocilloporid corals. Coral Reefs, 15: 59-66.

Tioho, H., Tokeshi, M. \& Nojima, S., 2001. Experimental analysis of recruitment in a scleractinian coral at high latitude. Marine Ecology Progress Series, 213: 79-86.

Tomascik, T. \& Sander, F., 1987. Effects of eutrophication on reef-building corals. III. Reproduction of the reef-building coral Porites porites. Marine Biology, 94: 7794.

Tratalos, J.A. \& Austin, T.J., 2001. Impacts of recreational SCUBA diving on coral communities of the Caribbean islands of Grand Cayman. Biological Conservation, 102: 67-75.

Van Moorsel, G.W.N.M., 1983. Reproductive strategies in two closely related stony corals (Agaricia, Scleractinia). Marine Ecology Progress Series, 13: 273-283. 1988. Early maximum growth of stony corals (Scleractinia) after settlement on artificial substrata on a Caribbean reef. Marine Ecology Progress Series, 50: 127-135.

Van Veghel, M.L.J., 1994. Reproductive characteristic of the polymorphic Caribbean reef building coral Montastrea annularis. I. Gametogenesis and spawning behavior. Marine Ecology Progress Series, 109: 209-219.

Van Veghel, M.L.J. \& Bak, R.P.M., 1994. Reproductive characteristics of the polymorphic Caribbean reef building coral Montastrea annularis. III. Reproduction in damaged and regenerating colonies. Marine Ecology Progress Series, 109: 229-233.

Van Woesik, R., 1985. Coral communities at high latitude are not pseudopopulations: evidence of spawning at $32^{\circ} \mathrm{N}$, Japan. Coral Reefs, 14: 119-120.

Van Woesik, R., Lacharmoise, F. \& Köksal, S., 2006. Annual cycles of solar isolation predicts spawning times of Caribbean corals. Ecology Letters, 9: 390-398.

Vermeij, M.J.A. \& Bak, R.P.M., 2002. How are coral populations structured by light? Marine light regimes and the distribution of Madracis. Marine Ecology Progress Series, 233: 105-116.

2003. Species-specific population structure of closely related coral morphospecies along a depth gradient $(5-60 \mathrm{~m})$ over a Caribbean reef slope. Bulletin of Marine Science, 73 (3): 725-744.

Vermeij, M.J.A., Diekmann, O.E. \& Bak, R.P.M., 2003a. A new species of scleractinian coral (Cnidaria, Anthozoa), Madracis carmabi n. sp. from the Caribbean. Bulletin of Marine Science, 73 (3): 679-684.

Vermeij, M.J.A., Fogarty, N.D. \& Miller, M.W., 2006. Pelagic conditions affect larval behavior, survival and settlement pattern in the Caribbean coral Montastrea faveolata. Marine Ecology Progress Series, 310: 119-128.

Vermeij, M.J.A., Sampayo, E., Bröker, K. \& Bak, R.P.M., 2003b. Variation in planulae release of closely related coral species. Marine Ecology Progress Series, 247: $75-84$. 
2004. The reproductive biology of closely related coral species: gametogenesis in Madracis from the southern Caribbean. Coral Reefs, 23: 206214.

Veron, J.E.N., 1974. Southern geographic limits to the distribution of Great Barrier Reef hematipic corals. Proceedings of the $2^{\text {nd }}$ International Coral Reef Symposium, 1: 465-473. 2000a. Corals of the World v. 3. In M. Stafford-Smith, ed. Corals of the World. Townsville: Australian Institute of Marine Science, 2000. 2000b. Corals of the World v. 2. In M. Stafford-Smith, ed. Corals of the World. Townsville: Australian Institute of Marine Science, 2000.

Veron JEN (2006) Darwin Medal presentation: Corals - seeking the big picture. Coral Reefs 25: 3-6.

Wallace, C.C., 1985. Reproduction, recruitment and fragmentation in nine sympatric species of the coral genus Acropora. Marine Biology, 88; 217-233.

Ward, S., 1992. Evidence for broadcast spawning as well as brooding in the scleractinian coral Pocillopora damicornis. Marine Biology, 112: 641-646.

Ward, S. \& Harrison, P.L., 2000. Changes in gametogenesis and fecundity of acroporid corals that were exposed to elevated nitrogen and phosphorus during the ENCORE experiment. Journal of Marine Biology and Ecology, 246: 179-221.

Weber, M., Lott, C. \& Fabricius, K.E., 2006. Sedimentation stress in a scleractinian coral exposed to terrestrial and marine sediments with contrasting physical, organic and geochemical properties. Journal of Experimental Marine Biology and Ecology, 336: 18-32.

Wells, S.M., 1995. Science and management of coral reefs: problems and prospects. Coral Reefs, 14: 177-181.

Willis, B.L., 1985. Phenotypic plasticity versus phenotypic stability on the reef corals Turbinaria mesenterina and Pavona cactus. Proceedings of the $5^{\text {th }}$ Coral Reef Congress, 4: 107-112.

1990. Species concepts in extant scleractinian corals: considerations based on reproductive biology and genotypic populations structures. Systematic Botany, 15 (1): 136-149.

Willis, B.L. \& Ayre, D.J., 1985. Asexual reproduction and genetic determination of growth form in the coral Pavona cactus: biochemical genetic and immunogenic evidence. Oecologia, 65: 516-525.

Willis, B.L., Madeleine, J.H.V.O., Miller, D.J., Vollmer, S.V. \& Ayre, D.J., 2006. The role of hybridization in the evolution of reef corals. Annual Review of Ecology, Evolution and Systematics, 37: 489-517.

Wilson, J.R. \& Harrison, P.L., 1997. Sexual reproduction in high latitude coral communities at the Solitary Islands, Eastern Australia. Proceedings of the $8^{\text {th }}$ International Coral Reef Symposium, 1: 533-538.

2003. Spawning patterns of scleractinian corals at the Solitary Islands - a high latitude coral community in the eastern Australia. Marine Ecology Progress Series, 260: 115-123.

Wyers, S.C., 1985. Sexual reproduction of the coral Diploria strigosa (Scleractinia, Faviidae) in Bermuda: research in progress. Proceedings of the $5^{\text {th }}$ International Coral Reef Congress, 4: 301-306.

Zakai, D. \& Chadwick-Furman, N.E., 2002. Impacts of intensive recreational diving on reef corals at Eilat, northern Red Sea. Biological Conservation, 105: 179-187.

Zakai, D., Levy, O. \& Chadwick-Furman, N.E., 2000. Experimental fragmentation reduces reproductive output by the reef-building coral Pocillopora damicornis. Coral Reefs, 19: 185-188. 